enorden 



\title{
Measuring Work Well-Being and Productivity in the Nordic Countries
}

\author{
A manual \\ Lars Foldspang, Michael Mark, Kristian Mørk Puggaard, \\ Otto Melchior Poulsen, Ulf Johansson, Guy Ahonen and \\ Steinar Aasnæss
}

TemaNord 2011:569 
Measuring Work Well-Being and Productivity in the Nordic Countries

A manual

Lars Foldspang, Michael Mark, Kristian Mørk Puggaard, Otto Melchior Poulsen, Ulf Johansson, Guy Ahonen and Steinar Aasnæss

TemaNord 2011:569

ISBN 978-92-893-2293-5

(C) Nordic Council of Ministers, Copenhagen 2011

This publication has been published with financial support by the Nordic Council of Ministers. But the contents of this publication do not necessarily reflect the views, policies or recommendations of the Nordic Council of Ministers.

www.norden.org/pub

\section{Nordic co-operation}

Nordic co-operation is one of the world's most extensive forms of regional collaboration, involving Denmark, Finland, Iceland, Norway, Sweden, and Faroe Islands, Greenland, and Åland.

Nordic co-operation has firm traditions in politics, the economy, and culture. It plays an important role in European and international collaboration, and aims at creating a strong Nordic community in a strong Europe.

Nordic co-operation seeks to safeguard Nordic and regional interests and principles in the global community. Common Nordic values help the region solidify its position as one of the world's most innovative and competitive.

\section{Nordic Council of Ministers}

Ved Stranden 18

DK-1061 København K

Phone (+45) 33960200

www.norden.org 


\section{Content}

Preface

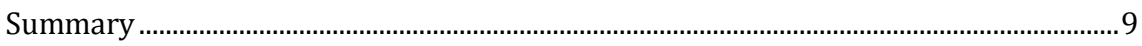

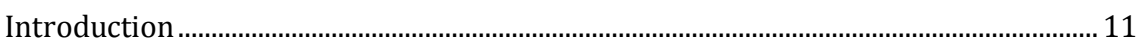

1. The Theoretical Model ............................................................................................... 15

2. Definitions of Work Well-Being.............................................................................. 17

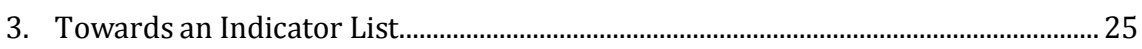

3.1 Company work well-being practice ……...................................................... 25

3.2 Physical Conditions and Exposures …………......................................................... 36

3.3 Psychosocial Conditions.................................................................................. 39

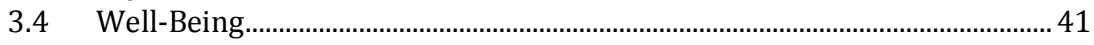

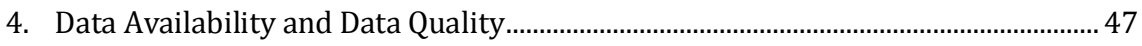

4.1 Company Work Well-Being Practice ................................................................... 47

4.2 Indicators Regarding Physical Conditions and Exposures............................. 48

4.3 Indicators Regarding Psychosocial Conditions................................................... 49

$4.4 \quad$ Indicators Regarding Well-Being........................................................................ 50

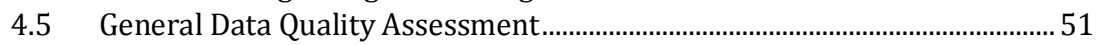

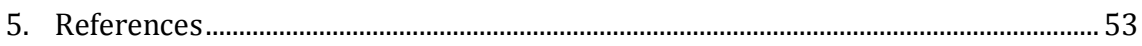

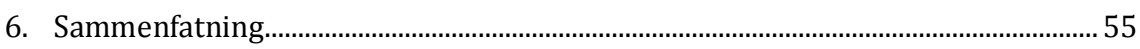

7. Appendix A: Data Availability and Data Quality ….................................................. 57

7.1 Testing Data Availability................................................................................... 57

7.2 Indicators Regarding Company Work Well-Being Practice ........................... 59

7.3 Indicators Regarding Physical Conditions and Exposures .............................. 97

7.4 Indicators Regarding Psychosocial Conditions..............................................115

7.5 Indicators Regarding Well-Being................................................................130 



\section{Preface}

Globalisation pressures and demographic trends affect the chances of the Nordics to be prosperous and indirectly threaten the welfare states as we know them. These pressures and trends underline the twin challenge to the Nordics of productivity stagnation and a decreasing work force. A contribution to an answer to both challenges can be an increase in productivity and new ways to increase the work force.

A good work environment can do both: If less people have to take sick leave as result of bad work environments, this will contribute to increasing the work force. Also, for some time, a relationship between work environment and productivity has been hypothesised. Happy, healthy workers, in short, are more productive than not-so-happy and not-so-healthy workers are.

Therefore, the main objective of the Nordic Council of Ministers' cooperation in the area of working environment is to promote health and welfare at work and thus productivity in society.

In this context, the Nordic Council of Ministers has initiated a project aiming at clarifying the impact on productivity of work environment and well-being in companies. This report presents an indicator manual for use in measuring work environment in the Nordic countries. The report also outlines and defines a common Nordic concept of work well-being.

The purpose of the indicators presented and the common Nordic concept of work well-being are to serve as important first steps on the way to a thorough econometric analysis of the relationship between work environment, well-being, and productivity. 



\section{Summary}

This report provides an indicator manual for the measurement of work environment and well-being. It thus completes phase 1 of a project in three phases on the possible connection between work environment, well-being, and productivity.

This relationship - between well-being and productivity - has been investigated before. However, to the knowledge of the authors of this report, no study has been conducted carrying out thourough econometric analysis across the Nordic countries of the relationship. This indicator manual is a first step on the way to conducting such analysis.

The indicator manual outlines and defines a common Nordic concept of working environment, occupational health, well-being, workability and other concepts related to this area. It further identifies indicators for the measurement of the different aspects of working environment. Finally, the report presents sources of data for each of the indicators from the four countries Finland, Sweden, Norway, and Denmark.

The data sources are rated according to the availability of data, the relevance, availability, accuracy, and comparability across the four countries. The manual shows that although some of the indicators, which could be helpful in a complete description of work environment and well-being, cannot be measured in all of the aforementioned countries, there appears to be firm ground on which to base thorough econometric analyses of the relation between work environment, well-being, and productivity.

The project, funded by the Nordic Council of Ministers, was conducted by a group of experts, consisting of:

- Otto Melchior Poulsen, The National Research Centre for Working Environment (Denmark)

- Guy Ahonen, Työterveyslaitos/Finnish Institute of Occupational Health (FIOH), Finland

- Steinar Asnaess, STAMI, Norway

- Ulf Johansson professor at Mälardalen University, Sweden

in co-operation with the research based consultancy DAMVAD of Copenhagen, Denmark. 



\section{Introduction}

This paper will try to outline and define a common Nordic concept of working environment, occupational health, well-being, workability and other concepts related to this area. Furthermore, the paper will outline a list of theoretically defined indicators, meant to be measureable when measuring the different aspects of working environment.

In this paper, we generally use the term work well-being as an umbrella for the concept covering many different issues including the elements mentioned above. The terminology is explained more thoroughly in section three.

The paper explores different aspects of work well-being and outlines a series of indicators which are supposed to reflect the different aspects of working environment and make it possible to measure working environment.

\section{Background}

The Nordic countries face shared challenges to be addressed in order to preserve growth and prosperity in the coming years. Demographic trends mean that in the coming decades the work force will decrease significantly in numbers and at the same time, the number of elderly people who require nursing will increase. This involves a financial challenge for public finances. And it means that there is a growing labour shortage in both the private and public sector.

Concurrently, the Nordic countries face a great challenge with respect to productivity. The Nordic countries share the same problem of having generated too little increased value per work input, with the risk of a deterioration in our competitiveness. Since we will face a future labour shortage, there is a risk of a lower standard of living in the Nordic countries.

It is therefore both necessary to increase the workforce in the Nordic countries and to increase productivity and competitiveness.

\section{One way to face these challenges can be through improved work well-being}

Improved health and well-being could have a positive effect on labour supply through lower absenteeism, reduced marginalization from the labour market and later retirement.

International studies indicate that there may be increased productivity through better work well-being. The effects will be expected to occur 
in both the private and public sectors. However, there remains robust statistical evidence of links between work well-being and productivity. Specifically, there is a lack of knowledge about how well-being at work affects productivity in different types of businesses (across industries, size, etc.). Literature reviews reveal that there is very limited evidence based on economic quantitative analyses examining and documenting this relationship.

\section{Purpose of This Report}

In order to overcome this lack of knowledge, the Nordic Council of Ministers has initiated a project with the aim of finding ways to conduct econometric analyses to determine the relationship between work wellbeing and economic performance in companies. The overall purpose is to try to determine the effects on company performance of company work well-being efforts.

The project consists of three phases:

- Development of a theoretical model and identification of relevant indicators and data sources across the Nordic countries

- A feasibility study regarding the collection and quality assessment of data from the four countries

- Performing econometric analyses in order to determine the relationship between company performance of company work wellbeing efforts

This report is the final deliverable in the first phase of this project.

The relationship between work well-being and productivity is a complex area. Before it is possible to carry out proper assessments of possible relationships, it is necessary to establish a solid conceptual framework and acknowledged understanding of how the area can be examined across the Nordic countries. It is also necessary to identify available Scandinavian data sources, making it possible to carry out valid and comparable analyses across the Nordic countries.

Hence, the purpose of this report is three-fold:

- To outline a common Nordic conceptual framework and definition of work well-being

- To identify theoretical indicators of the various aspects of work wellbeing for micro-econometric analysis of correlations between health, well-being and productivity

- To assess available Nordic data that can be used to analyze different aspects of relationships between work well-being in companies and productivity 
The Nordic manual for measuring work well-being is supposed to be the basis for further studies in phase two of this project.

\section{Organisation of the Project}

To achieve this goal this project has been funded by the Nordic Council of Ministers. The project is being conducted by experts of work wellbeing across the Nordic countries.

Participants in the project are:

- Lars Foldspang, Michael Mark, Jesper Sørensen and Kristian Mørk Puggaard, DAMVAD, Denmark

- Otto Melchior Poulsen, The National Research Centre for Working Environment (Denmark)

- Guy Ahonen, Työterveyslaitos/Finnish Institute of Occupational Health (FIOH), Finland

- Steinar Asnaess, STAMI, Norway

- Ulf Johansson professor at Mälardalen University, Sweden

This paper is based on a series of national contributions from the members of the project group from Denmark, Finland, Norway and Sweden. Each of the members has forwarded a of review over national literature and research concerning work well-being. The national papers deal with three different issues:

- A national definition of work well-being from each of the four countries which is based on research and includes all the relevant elements and excludes all irrelevant elements of the definition

- A national series of indicators regarding work well-being in each of the countries. This is a set of indicators in order to be able to analyse the status of the working environment

- A national series of indicators from each of the countries regarding how companies work to improve the work well-being

Furthermore, each member of the project groups has identified and described available data sources for measuring the indicators in each of the countries. 



\section{The Theoretical Model}

The theoretical model is depicted in the chart below.

The basic hypothesis of the model is that improving the work wellbeing of employees will improve productivity because risks, uncertainty, hostile conditions, injuries, toxic exposures, etc. all remove resources away from the working tasks into unproductive actions.

According to Becker and Huselid, improving the work well-being of workers pays off, because it gives a strategic advantage to the company (Becker \& Huselid 1998). The blue boxes are the topics in focus in this paper.

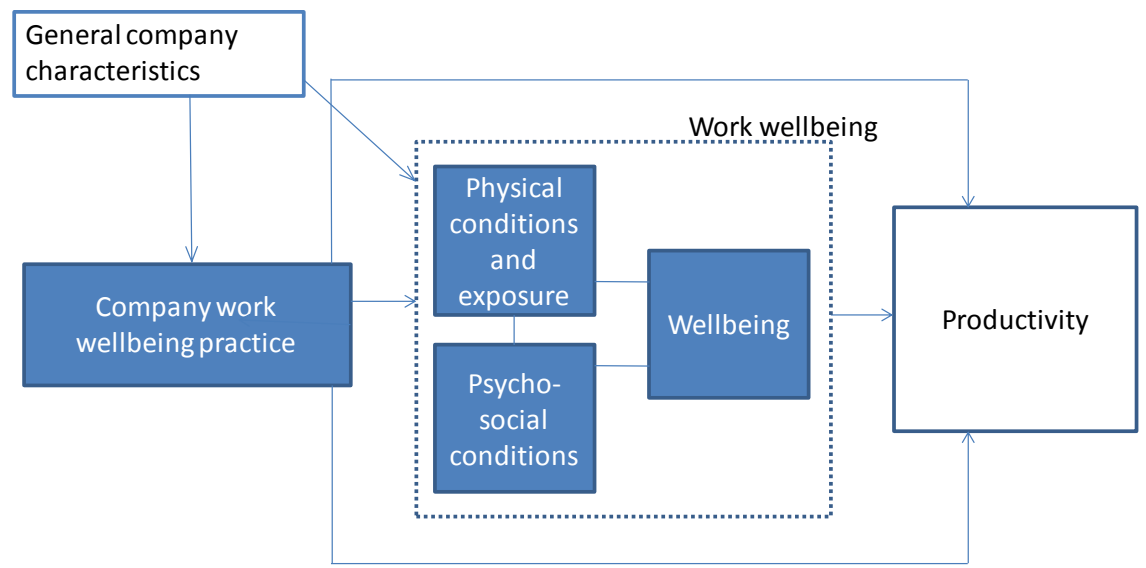

Chart 2.1 Overall model for company practice, work well-being and productivity Source: DAMVAD and expert group, 2011

The idea behind the theoretical model is to investigate how work wellbeing efforts affect productivity. Efforts can be undertaken both at company and individual level. Thus, the model operates with the company level as well as the individual level. It is important to note that although the causality can in theory very well run from company practice and company work well-being effort (company level) to individual wellbeing of the workers, the measurement of company level factors can be extremely difficult, because these are, to some extent, experienced differently by different individuals. For example, to the extent workers are asked, not all of them will find that a specific company is doing a great job promoting the work well-being of its employees.

When conducting analyses, the model enables the researchers to adjust one or more efforts in one or more of the four boxes in order to investigate effects on productivity. The adjustments can be done sequential to isolate and investigate the effects of a single effort. Or the adjust- 
ments can be done simultaneously to investigate the effects of different combinations of work well-being efforts.

Finally the model allows for including general company characteristics. This is done in order to isolate the effects of adjustments in work wellbeing effort and thus making sure, that observed changes in productivity is not an effect of a change in exports, R\&D level, the educational level of the employees or other things usually affecting productivity. 


\section{Definitions of Work Well-Being}

The definition of work well-being covers a broad range of objectives and underlying factors. The differences in the definitions are a consequence of the constant change in focus of work well-being due to changes in society, technology and knowledge about work well-being. As such the definition of work well-being will never be definitive, but will always be subject to the changes in norms of society, ways of organizing work, technological landmarks and new knowledge.

Despite these challenges this chapter focuses on the definition of work well-being. In relation to the definition, the term work well-being will cover work environment, work well-being, employee well-being and occupational health. This distinction will be presented when there are direct references from the contributors of this brief note.

The focus on work well-being is related to an increasing insight into the importance of work well-being. One aim of focusing on work wellbeing is to accomplish healthy workplaces and prevent the worker from being stressed, ill, hurt or exposed to accidents. A healthy workplace has several implications both to the individual, the company and the society as a hole. First, the workplace has huge impact on each individual health situation and therefore work well-being is central to individual health and their safety at work. Second, work well-being is a significant issue in employment policy among others to increase labour supply. Third, work well-being is important to the overall health policy in terms of decreasing illness among the population, absenteeism from work and improved living standard. As such, work well-being concerns both the exposure of risks and a way to increase individual and company resources.

\subsubsection{Definitions}

Traditionally, work well-being has focused on the physical conditions at the workplace. Throughout the 70's there has been a broadening focus on work well-being to include psychological, chemical and biological work well-being. The vast literature also depicts this by focusing on a broader definition of work well-being. This focus has led to steps at governmental level to increase awareness on work well-being, e.g. Swedish Work Environment ACT from 1977 and a task force in Denmark appointed in 1972 and later, in 1977, legislations pointed specifically at work well-being. 
From the 1980's and onwards there has been an inclusive focus on work well-being. This includes not only focus on psychological and chemical factors but the physical factors too. It also includes relations and interactions between different individuals and parts of the work place and the surrounding society. Further, there has been focus on work well-being as a way of gaining more from the employees. As such work well-being both concern risks and resources.

In the Nordic countries there are similarities and differences in focus on work well-being.

In Finland, the definition of work well-being is the concept of promotion and maintaining work ability. This concept defines workplace activities aimed at maintaining the ability to work, including all measures that the employer, employees and the cooperative organizations at the workplace take in a united effort to promote and support the ability to work and to enhance the functional capacity of all persons active in working life throughout their careers.

The company is not the only entity in focus. Collaboration between members of the work community, as well as different work organizations is also strongly emphasized. As such, the focus of work well-being does not only include the individual level, but also organizational levels surrounding the individual both within the company, but also at the level of the work community.

In Norway, the definition evolves around work environment, work well-being and occupational health:

- Work environment: The work environment is focusing on the causeeffect-relationships between exposure at work and increased risk for diseases. The focus is to reduce the impact of harmful factors at work and to find work processes to reduce the risk of disease in those who work in the process

- Work well-being: Sum of the factors at work which the employee responds to whether physical, chemical, mental or social. It can distinguish between two sides: One is the prevention of negative effects, and the other is the exploitation of the potential positive effects in terms of safety and learning

- Occupational health: The promotion and maintenance of the highest degree of physical, mental and social well-being of workers in all occupations; the prevention amongst workers of departures from health caused by their working conditions; the protection of workers in their employment from risks resulting from factors adverse to health; the placing and maintenance of the worker in an occupational environment adapted to his physiological and psychological capabilities; and, to summarize, the adaptation of work to man and of each man to his job. (ILO, WHO) 
In Sweden, the definition of work well-being concerns the conditions at the work place. A specification of this definition state that factors affecting the employee is in fact work well-being. This means that the dynamics of the relationship between the work place and the employee is a centre. Further, the definition includes focus on occupational health. Occupational health is defined as ensuring a higher degree of protection of workers at work through the implementation of preventive measures to guard against accidents and occupational diseases and through information, consultation, balanced participation and training of workers and their representatives.

Another focus is on the healthy organization. The healthy organization is aiming at creating the best work well-being for the employees and consists of different factors such as organizational culture, occupational health and security and personal health practices. These factors, when used properly, adds to the well-being of the individual by giving them information and support to make positive choices that reduce risks and enhance their well-being. This implies both the physical, psychological and social health in the organization.

In Denmark the definition of work well-being encompasses interaction between relations, influences and conditions, which each person is performing under. It is also a question of the technical and social development at the workplace affecting the individual's safety in the short run and the physical and psychological well-being and health in the longer run. Further, general well-being is defined as balance, e.g. balance between the resources and the demands put forward. Well-being is promoted by positive expectations to handling everyday challenges and that the individual has physical and mentally surplus of energy. As such wellbeing is creating happiness, satisfaction and security.

\section{Elements Defining Work Well-Being}

Originally the main focus was on safety and factors that in the shorter or longer run could affect illness or accidents at the workplace. It encountered factors such as smoke noise, trash and muck as well as the risk of accidents at work. In time this has been expanded to also include impacts that affect health in the longer run. As such it is clear that work well-being not only consists of directly objective physical factors. Work well-being consists of physical, psychological and psychosocial factors, which both Danish, Swedish, Norwegian and Finnish research confirms. Therefore, work well-being focuses on two elements:

- Physical elements of work well-being

- Psychological and psychosocial elements - the psychological and psychosocial are combined as they are closely related and very often interrelated 
Even the basic and most simple definition of work well-being has rapidly become complex, because identifying work well-being comprise the following elements:

- Interaction: The physical, psychological and psychosocial factors interact with each other and as such work well-being becomes relatively complex

- Short or long term effects: Besides the interaction between the three elements one has to consider whether the causes have short or long term effects

- Individual or system effects: It should also be considered if the causes are affecting the individual or the organization or both. The system effects also include the work organizations

- Identifying the causes: In order to identify the different causes and determinants of work well-being, it is also important to gain knowledge about the objective and subjective measures and how these should be interpreted

One example of how the complexity is affecting research is found in Danish research. Here the definition of work well-being consists basically of two different aspects. One aspect is the causes and determinants of work well-being and another trail focuses on the consequences regarding health. This approach consists of numerous advantages, but can be very difficult or even impossible to implement. Therefore, the definition has been revised and it has been decided to return to the previous more traditional and unified definition of work well-being as something that is causing and affecting changes.

It is central in order to understand work well-being that the different aspects of physical, psychological and social factors are possible to identify. Therefore it is also of great importance to understand, in depth, how the different aspects can be identified, e.g. at what level should the different elements of work well-being be measured, how do they interact with each other, how is the impact on an individual and organizational level and what are the possible impacts both in short and long term.

Therefore the following will focus on physical, psychological and psychosocial factors and how these are defined and determined based on Swedish, Norwegian, Finnish and Danish research.

\section{The Physical Work Well-Being}

Physical work well-being was the initial focus and is perhaps the easiest part to measure. The physical work well-being is highly related to cause and effect. If the worker is less exposed to asbestos, chromium, nickel and vinyl chloride then the risk of developing various cancers lessens, as the Norwegian points out. Further, noise level, smoke and chemical risks are pointed out as elements affecting the physical environment. 
Safety is also an important element of physical work well-being. In the Danish case, there is focus on accidents at work and muscular and skeleton influences in relation to safety. In Finland, focus is on the health and safety of work, working methods and the work environment. In Norway the new labour life is affecting the health, environment and safety situation (HES issues) for Norwegian employees. In the Swedish case safety is mentioned in line with occupational health.

One way of meeting the challenges of bad physical work well-being is to take precautions related to safety and what is causing bad physical work well-being. Here, prevention in terms of physical exercise is being stressed as important in the Finnish and the Danish case (Mortensen et. Al. 2008). Physical exercise is an important factor because it has documented positive physical effects and because it increases mental resources.

The determinants of physical factors are traditionally interpreted as objective factors that in short or long term will affect the health of employees, e.g. Westlander in Hörte (2009) who adds that the objective factors are related to the physical work well-being and thereby is easily measured. The cause will mainly be related to the individual effects.

The physical factors will both have short term and long term effects. Obviously, an accident will have an immediate effect while the exposure of damaging radiation will have long term effects. When defining different causes and determinants it is clear that short term effects are easier to locate than long term effects.

\section{The Psychological and the Psychosocial Work Well-Being}

Another central element of defining work well-being is the psychological factors.

In Finland, there is an increasing focus on work related problems caused by psychological factors. Ahonen and Hussi (2007), state that increasing the knowledge-intensiveness of working life will modify the prerequisites of work. Because of increasing computerization and structural changes, about $70 \%$ of the Finnish labour force is working on tasks that are based on clerical content. On the other hand, tasks that have been non-technical by nature are also becoming increasingly technical in nature implying high performance systems. The radical changes in content and methods of work imply challenges to professional qualifications. If these qualifications are not met, it can rapidly turn into serious problems in working life, causing stress and other problems.

In the Swedish case, Westlander (in Hörte, 2009) elaborates upon and classifies different psychosocial approaches. Based on theories developed in the 1970's she suggests that these psychosocial factors and theories could stand for either ideas about causality between work conditions and the individual, or about consequences in terms of the individuals feelings, experience or actions, or about the interrelationship between work conditions and the individual. These three perspectives 
could equally well be used for discussing how other work conditions affect the employee.

In Denmark, there is a recognition that the pressure from psychological stain will increase. In a report from 2010 regarding the future of work well-being it is stated that both the quantitative and qualitative demands will increase and as such continue a trend, which has been identified from year 2000 to year 2005 .

The psychological factors cover a broad range of factors that are interacting. It is important that the individual perceptions of the surrounding conditions, challenges and opportunities compared to the individual goals and aspirations (in work as well as private sphere) have immense results for the psychological reactions (Lazarus 1999).

For instance, stress and work stress are in focus in Norway. Stress is defined as the result of any emotional, physical, social, economic, or other factors requiring a response or change. Work stress is the relationship between stressors on the job and how the worker physically and emotionally reacts. Stress at work can also involve job security, unstimulating work, salary problems and other issues. Both the Finnish and Swedish case focuses on different stressors such as responsibility, motivation, work schedules, motivation, self-fulfilment, the meaningfulness of work, the control of exposure and strain, work life balance. All are factors affecting well-being and hence potentially productivity.

Another stressor could be over commitment at work, which is to bind or obligate (oneself, for example) beyond the capacity for realization. Also job security, defined as the probability that an individual will keep his or her job; a job with a high level of job security is one where the person with the job would have a small chance of becoming unemployed.

The interaction element of the psychological and the psychosocial factors is often very present. Actually the effects on work well-being from the psychological and the psychosocial are caused by interactions between different factors. These different factors and their interaction are both affecting the individual, the organization and both at the same time.

Identifying the causes can be a complex matter. The strong element of interaction of factors between the individual and organizational level combined with uncertainties make identification of psychological and psychosocial factors a difficult task and maybe even impossible to achieve a generic definition.

\section{Towards a Common Definition}

One of the objectives of the project is to find a common and pragmatic definition of work well-being. It is important to stress that the definition is not a final definition. This is the definition in this project. 


\section{Elements in the Definition:}

- The objective and

- subjective

- physical and

- psychosocial well-being of the employees

- individually and social relationships

- the factors in the physical and psychosocial environment in the organization or in the work community that addresses the physical and psychosocial risks and resources of the employees

Source: DAMVAD and expert group, 2011

The physical well-being of the employee includes the overall health and safety of the employee including the identifiable workplace, causes of accidents and illness.

The psychosocial well-being of the employee includes, among others, a set of job factors related to the interaction between people, their work and the organization.

The individual factors of work well-being include all personal factors both physical and psychosocial well-being as well as the fact that the work well-being is filtered through individual perceptions.

The organizational factors of work well-being include, among others, the organization of healthy and safe ways of work, interaction with others in the group, i.e. colleagues and superiors. The physical and psychosocial environment in the organization can, by preventive actions, promote and support the physical and psychosocial well-being of the employees, among others the balance between work and leisure, information and influencing attitudes. As a supplement to addressing risk factors, work places can also treat bad work well-being in terms of reacting when the problem arises, e.g. by intervention, treatment etc.

The work atmosphere, social support and control over work tasks experienced by the employee are increasingly important as prerequisites of work ability and thereby important to work well-being. Therefore, the development of work communities becomes increasingly important to companies and employees. The work communities are putting up the frames, rules and legislations, which help companies and employees to settle any disputes or expectations between employer and employee.

The ability to determine the cause and effect of the physical and psychosocial factors both short term and long term effects. 



\section{Towards an Indicator List}

The indicators were selected on basis of the expert inputs. Three groups of indicators appeared to be the centre of discussion in the expert inputs. These three groups correspond to the blue boxes in figure 2.1.

- Work or work well-being indicators, corresponding to company practice

- Workers' health, corresponding to company work well-being (status indicators)

- Companies' improvement efforts, corresponding to company work well-being improvement efforts

The indicators should cover fact based or "objective" factors as well as "subjective" or self-reported factors. Also, they must cover work wellbeing at the individual as well as the organizational level. Finally, physical as well as psycho-social work well-being should be covered, as should short term as well as long term effects.

\subsection{Company work well-being practice}

The physical and psychosocial well-being of the employee is affected by the way the company functions in general. This includes a lot of different aspects such as:

- organisation of work

- organisation of working hours

- individual influence

- the demand and work load

- supervisory practises

- culture and social support

These factors influence the work well-being of the employee whether they are subject to deliberate work well-being actions and effort by the work place or not. Some of the factors may be adjusted easily as a consequence of a work well-being action while others can be more difficult to adjust.

Company practices regarding improvement of work environment relate to the way companies work specifically to improve the work environment. The subject can be divided into different groups. Working environment improvement practices are generally subject to top manage- 
ment decisions or include decisions in which the top management includes other management levels as well as employee representatives.

Furthermore, the psychological health is to a large degree also a question of management practices since the management is responsible for handling the psychosocial health situation at the work place. The management can decide to develop certain tools or inaugurate specific practices in order to improve the working environment.

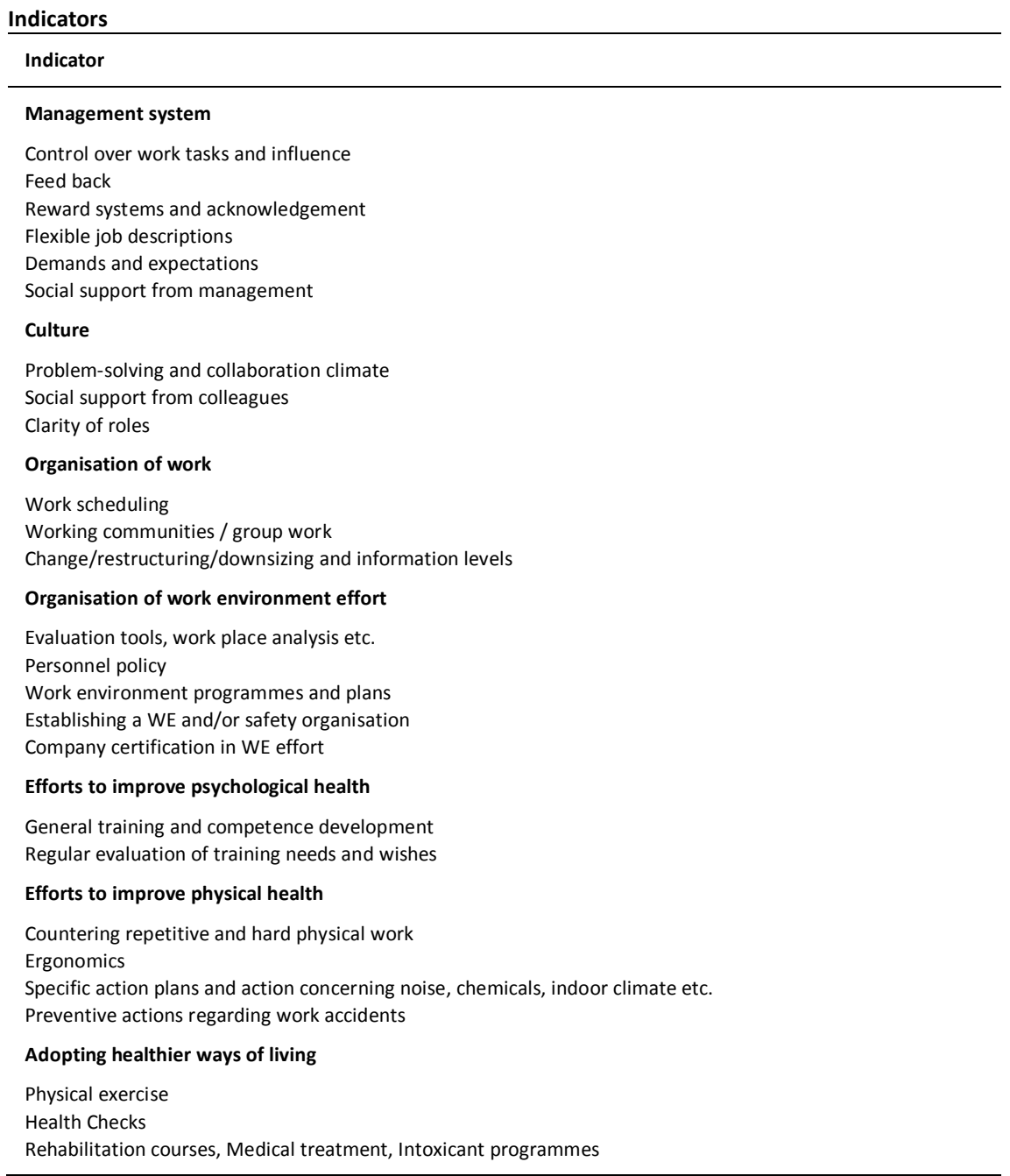

Source: DAMVAD and expert group, 2011.

\section{Job control and influence}

- Does the company give the employee control over how to perform work tasks?

A general and important issue across the WE literature is to what extend the employees have control over the tasks they are to perform themselves. Therefore, it is important to evaluate if and how companies aim at empowering the employees, to which extent they give the autonomy and predictability in the work effort. Specific company measures in this 
area could be decisions regarding work tasks, colleagues to perform the work task with, improved communication regarding the tasks, flexibility regarding how, where and when to perform the tasks etc.

\section{Feedback}

- Does the management give regular and fair feedback to employees?

Feedback is an important part of the psychological work environment. Feedback from managers and management is a way for employees to learn about and improve their performance as well as a way to get information about their job situation, future etc. Therefore feedback is in many cases seen as an important tool to promote work environment for employees as well as a way to have an open dialogue on how to ensure that performance is at the expected level. However, it is important to make sure that feedback is given in the right way in order to make sure that feedback is given in a constructive manner.

\section{Reward Systems and Acknowledgement}

- Does the company reward the employees appropriately in accordance with their efforts?

Rewarding can be many things. However, across Norway, Sweden and Finland, given an appropriate and fair award related to the results of the employee is stated as important. This is related to and can be a specific way of acknowledgement of results from the management, which is also an important factor regarding the psychosocial work environment. A sub-theme within this indicator is whether the company has specific systems for rewarding.

\section{Demands and Expectations}

- Are the demands and expectations towards the employee reasonable?

Demands and expectations are important factors for work well-being. The sense of being able to deliver what is expected is closely related to expectations regarding job security as well as hopes regarding wage and career potential. Therefore high and unrealistic expectations regarding effort increase uncertainty for the employee. This includes demands exceeding the qualifications of the employees as well as demands in relation to the work load expected to be performed.

Another important theme that can be explored is whether there is a reasonable and realistic work load compared to the abilities, resources and skills of the employee. Unrealistic expectations in these matters are to a high degree correlated to work-related stress, failure and uncertainty.

Psychosocial and organizational factors are important in the development of mental disorders. Among the best documented risk factors for 
depression (Stansfeld 2006, Bonde 2008) research finds job demands combined with low control and low social support. However, this is also related to effort-reward imbalance and poor climate of cooperation ("team climate").

\section{Flexible Job Descriptions}

- Does the work place use flexible job descriptions?

An aspect closely related to control over work tasks as well as influence and repetitive work is whether companies have flexible job descriptions for employees. This enables for job rotation, professional development, influence on daily tasks etc. (Ahonen 2008).

However, some studies show that functional flexibility is not directly linked to productivity (van der Meer, PH and Ringsdal, K 2009).

\section{Social Support from Management}

- Does the management support the well-being and well-functioning of the individual employee?

Social support from the management appears to be linked to absence in the way that lack of support causes absenteeism. This is linked to the fact that support from management gives a sense of job security as well as backing up the employees socially ensures that bullying or other negative behaviour from co-workers is less frequent. Furthermore, social back-up from the management can take form of helping employees in tackling difficult situations in the private sphere and ensuring work-life balance if there should be any issues which demand consideration.

\section{Problem- Solving, Dialogue Oriented Collaboration Climate}

- Does the workplace promote a climate of collaboration and constructive dialogue?

A climate of collaboration is seen as having a positive impact across the countries. This goes for vertical as well as horizontal collaboration. At the core of this is dialogue and a question-and-answer-oriented interaction as well as the culture of challenging ideas in a constructive manner. However, tolerance for challenging ideas systemically and contradictions is demanding for the work community. Establishing a wellfunctioning team climate is therefore important in many ways. Research has also shown that problem-solving situations and considerations are part of a safe work practice of the work community and that personnel meeting each other as individuals concerned with the well-being of each other is linked to good work practice (Anttonen et al. 2008). 


\section{Social Support from Colleagues}

- Which level of social support among colleagues is present in the company?

The social work well-being has an impact on the psychological wellbeing of the employees. Social support from colleagues is in many studies viewed as important aspects of the work well-being. Social support makes the employee feel included in the community, helps if the employees have either professional or private difficulties and gives a form of feeling of security for the employee.

Work factors related to musculoskeletal complaints and disorders have been reviewed in a recent report from the National institute of occupational health in Norway (Stami report 2008). Lower levels of social support are found to be an important risk factor for back pain and sickness absence due to back pain.

\section{Clarity of Roles}

- Is it obvious who has the responsibility for different tasks and who has different roles?

The distribution of various tasks among the employees and the level of responsibility is important for the employees in order to experience a certain amount of security and predictability among the working tasks. Uncertainty regarding who has the final word implies a potential for conflict and thereby a bad work well-being. Clarity gives the employee predictability as well as control over the work tasks. Furthermore, clarity makes it easier to know, what is expected by the employer.

\section{Work Scheduling}

- Is the work organized and scheduled in an appropriate way?

WE can to a large degree be defined by the way the work is scheduled and the amount of work expected by the employer. This is a subject that includes many sub-themes. A theme is how the work is scheduled with regards to working hours, daytime/night-time and the opportunities to get reasonable rest. If the employer expects that the employees work many hours each day, it can be stressing and even though it can improve the production volume in the short run, it can also undermine the effort in the longer run as long as employees are stressed, rundown etc. Furthermore, if the work is scheduled to hours making it difficult for the employees to have a well-functioning work/life balance, it can in the longer run cause absenteeism, high employee turnover etc.

Another aspect is whether the working hours are changing or more or less fixed. Changing working hours, e.g. as part of shift work, imposes 
a stress to the human organism in terms of difficulties with having a circadian and biological rhythm.

\section{Working Communities / Group Work}

- Is the work organized in individual or group work?

Working communities is a way of organizing the work in a work place. This implies that the individual employee is not necessarily responsible for the total delivery in the project. Furthermore, organizing in working communities also enables to ensure social support from colleagues as well as distributing workloads among several employees.

In Finland, collaboration between members of the work community, as well as different work organizations, is strongly emphasized. An individual is an active doer and participator instead of a mere object in this framework. This means adopting new work roles and the courage to build new ways of collaboration. (Ahonen, Hussi, 2007).

\section{Evaluation Tools}

- Does the company evaluate the work well-being?

In order for a company to work strategically with work well-being it can be necessary to assess the actual work well-being in the company. Using tools in order to assess oneself enables companies to find out where improvement is needed. Furthermore, it can form the basis of a dialogue and a process for improvement of the work well-being.

This area is in many countries subject to presence of a lot of tools. In Finland one finds the Y-step. The Y-STEP is based on five main steps in health promotion: preparation, self-evaluation, planning, execution, and evaluation. The goal is to make one's own plan for well-being and health promotion, and to make it work. The Y-STEP matrix contains evaluation for 1) entrepreneur's health and well-being, 2) organization of work, 3) professional skill development, and 4) work environment. Score ranges are ranked in terms of good practice, high standard practice and excellent practice. (Anttonen et. al 2008)

In Denmark the work place evaluation scheme (Arbejdspladsvurdering) is mandatory for all companies with employees. The purpose of the scheme has been to provide a tool for work environment evaluation. The effect is not yet known, however, companies report that it has a positive effect on work well-being.

In Finland a self-evaluation matrix has been designed for SMEs. It gives a general view of the standard of well-being at work activities in the organization. However, the calculated scores have no absolute comparative value and are not recommended for benchmarking, as the needs of workplaces vary considerably. The matrix is best used as a basis for discussion to develop activities within an organization (Anttonen et. al 2008). 
In an empirical investigation of seven big Swedish firms (e.g., Swedbank) Johanson et al (2001) demonstrate how habits and routines were evolutionary changed to support the new management and measurement system addressing different intangible resources (WE and $\mathrm{OH}$ ).

\section{Personnel Policy}

- Does the company have a personnel policy regarding work wellbeing?

Personnel policy can be a strategic framework for defining well work well-being practice in the company in order to make sure that there is a common way to work with work environment. Furthermore, it can regulate some of the most obvious challenges and questions in work practice in the company and be the foundation for a corporate culture regarding various aspects of work well-being.

In the strategic wellness management index in Finland, personnel policy was rated $10 \%$ out of $100 \%$ being one of five main indicator groups.

\section{Work Well-Being Programs and Plans}

- Does the company have a work environment program or work wellbeing plan in order to promote work well-being?

A strategic way to promote better work well-being is by using a work well-being plan or establishing a program in order to promote work well-being. Having identified focus areas or crucial challenges to address either beforehand or as a reaction of an identified problem implies that there is a possibility to address the issues. A program or a plan highlights the steps to be taken and places responsibility for the different tasks to be taken. Research suggests that successful work well-being requires a clearly defined programme with explicit goals and time limits. The goals must be in proportion with the organization's other activities (Ahonen, Hussi, 2007).

An element which could be taken into consideration is how the company and the employees are involved in the formulation as well as the execution of the plan. The Finnish Metal Age method for participatory workplace health promotion was developed by Näsman and Ilmarinen (1999). The model is designed to identify problems and opportunities at work and generate positive manageable solutions to them. The process includes the personnel of the company or organization. All relevant development areas in order to increase their well-being at work are identified. The prioritizing of initiatives is made by using a priority matrix. All participants are asked to rate the importance, prevalence and possibility to influence on a scale between 1 and 10. A total score is achieved by multiplying the ratings. The development area with the highest score is 
then taken for a more detailed analysis in order to agree on concrete actions, person in charge of them, and deadlines for their completion.

Work well-being plans could relate to different issues such as:

- Bullying

- Physical hard work

- Work accidents

- Chemicals and other dangerous materials

- Sedentary work

\section{Work Well-Being or Safety Organization}

- Does the work place have an organizational unit handling work wellbeing issues?

A company having a specific organizational unit in order to handle work well-being issues has the ability of having work well-being on the agenda for the entire company, continuously follow the development, take immediate actions etc. A unit handling work well-being questions is seen as a way to professionalize work well-being issues. It can take different forms - as a human resources unit with professionals working with work wellbeing, at a daily basis or as a committee handling political matters.

It ensures that work well-being is on the agenda from time to time and it ensures that there is a forum in which to handle issues regarding work well-being on a regular basis. This could be in terms of the daily dealing with specific challenges as well as taking preventive actions. And it could be in the form of organizing knowledge, feedback and making more principal decisions regarding work well-being in the work place.

In the strategic wellness management index in Finland, wellness organization and budgeting was rated $14.5 \%$ out of $100 \%$ being one of five main indicator groups (Aura et al. 2010). Danish companies having more than 20 employees are required to have a safety committee and/or a safety representative for the employees.

\section{Certification in Work Well-Being}

- Is the company certified in handling the work well-being in one way or another?

A certification can work as a way to make the work more systematic with work well-being as well as documenting the effects. Furthermore, certification often implies that companies must spend more resources in their work environment effort. Finally, it gives the opportunity to prove to employees, candidates, customers etc. that the company works seriously with work well-being.

In Denmark almost 3,000 companies have been certified by the Danish Working Environment Authority. 


\section{General Training and Competence Development}

- Does the company provide training and education for their employees?

An important factor for employees is whether they have opportunities to develop their skills within their job. Education and training give the employees better possibilities to keep their job and perform better. Furthermore it opens the opportunity for personal development.

The competence dimension is important because radical change in the content and methods of work imply major development challenges to professional qualifications practices. Deficiencies in professional skills can rapidly turn into a serious problem in working life. This is also a health-related threat as it creates a strain and increases work-related stress. Traditional technical planning competence and non-verbal skills are losing their importance. The skills related to verbal and symbolic interaction are increasingly important as different networks and contacts need to be used quickly when needed. Good connectivity through social skills helps an individual meet the uncertainty of the future. (Ahonen, Hussi, 2007).

Furthermore, training and education of employees can affect general economic performance in the companies directly, since many studies have shown a relationship between educational level in the company and productivity.

\section{Regular Evaluation of Training Needs and Wishes}

- Does the company in a systemized manner evaluate the need for training for individual employees?

In order to find out if employees have the appropriate skills and therefore are able to perform their job with satisfaction and have a future at the organization, the company can make a more regular evaluation of the needs for this. This can be done in many ways but the important thing is that it gives the opportunity to ensure that employees are and feel valuable for the work place.

If not, employees can become insecure about their future job situation as well as unsatisfied with their own performance.

\section{Training in Work Well-Being}

- Does the company or any of the employees in the company participate in training activities aimed at improving their work wellbeing skills?

The purpose with work well-being training is to strengthen the work well-being efforts in companies. In Denmark there has been an effort to develop training sessions for employees and managers in companies on 
work environment. There has been no evidence with regards to effects of this kind of training (Arbejdstilsynet 2010).

\section{Countering Repetitive Work and Hard Physical Work}

- Does the work place have actions to lower the degree of repetitive work and hard physical work as much as possible?

Repetitive work and hard physical work has been subject to many scientific studies as well as efforts from public organizations through time. The reason is that it is expected to correlate to a high degree with sickness and physical attrition of the employees in the longer run.

Therefore, it is also relevant to consider how companies work to reduce the repetitive work as well as hard physical work (Arbejdstilsynet 2010), (Alexanderson K et al. 2004).

\section{Ergonomics and Design}

- Does the company work to improve the ergonomic conditions in performing work tasks?

The physical aspect of work environment is important in all kind of workplaces. This also includes the workplaces that are not affected by hard physical labour or other physical risks. Some workplaces work deliberately to improve the ergonomic conditions for their employees regarding e.g. tables, laptops, work position, equipment, lifting techniques etc. in order to ensure that the work is not eroding the people involved in the shorter or longer terms.

Some companies do this preventive while others do this as a reaction to complaints or musculoskeletal disorders.

\section{Specific Action Plans and Action Concerning Noise, Chemicals, Indoor Climate etc.}

- Does the company have specific measures concerning improvement of the physical surroundings and work well-being?

A great part of the work well-being concerns physical issues affecting the health and well-being of the employees. This could relate to noise at the work space, indoor climate (temperatures, humidity, ventilation, hygiene etc.) but also relating to immediate risks like chemicals etc. To avoid problems related to these kinds of risks, companies can take measures to avoid causing physical risks at their employees. This could be by introducing security equipment, training of employees, maintenance and investments in physical facilities etc. 


\section{Preventive Actions Regarding Work Accidents}

- Does the company take preventive actions regarding avoiding work accidents?

In 2010 there were 44,381 work accidents in Denmark. 166 caused amputations and 39 were fatal (www.at.dk). This, of course, has major implications for the health among employees as well as costs related to the accidents. There are several ways companies can try to avoid work accidents. This can relate to routine security reviews of the workplace or implementation of action plans, but can also relate to investments in security equipment as well as maintenance, training etc.

\section{Physical Exercise}

- Does the work place in any way support the physical well-being of the employee in terms of giving access to or performing physical exercise in relation to the work place?

A central aspect of general and physical well-being is the general health conditions which also influences the well-being at the work place as well as the general well-being and performance of the employee.

Physical exercise has initially been a central aspect of promoting work environment because it is documented to bring positive physical effects and also increases mental resources (Ahonen, Hussi 2007).

\section{Health Checks}

- Does the workplace provide health checks for the employees?

An aspect of health promotion policies in workplaces refers to a general health promotion policy. Within this area it has become even more used in many workplaces to give the employees access to health checks which are supposed to promote their general health and well-being. This is expected to promote workability as well as loyalty towards the work place as long as it is voluntary.

There exists mixed results regarding the impact of health checks and health policy in companies, however, if the effort is targeted at risk factors and risk groups, there is an expectation that it could have a positive impact on work well-being as well as productivity.

\section{Rehabilitation Courses, Medical Treatment, Intoxicant Programs etc.}

- Does the work place offer health promotion activities to the employees including medical care?

In recent years health promotion programs directed towards employees has seen increased importance in workplaces. This is part of a proactive taking care of the health of the employees which is expected to yield 
positive returns for the companies due to lower absenteeism and higher productivity among employees as well as promoting the health of the employees.

The Finnish DRUVAN-project included several of these aspects as part of a larger work environment concept. However, some research indicates that there is no direct linked relationship to productivity (Kristensen 2010).

\subsection{Physical Conditions and Exposures}

Physical conditions and exposures constitute a central part of work wellbeing affecting employees' psychosocial and physical health.

Physical Conditions and Exposures

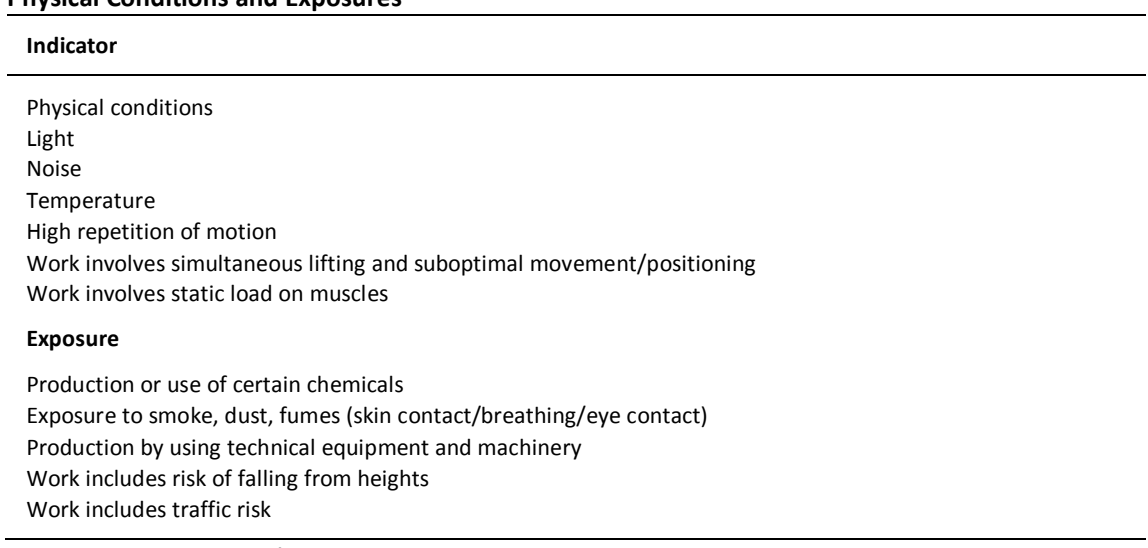

Source: DAMVAD and expert group, 2011.

\section{Light}

- Does the light give optimal working conditions?

A new Danish project hypothesises a strong connection between lack of exposure to daylight and the incidence of breast cancer. Also, there is a known relationship between a range of illnesses and working late hours - some of this relationship is sometimes hypothesised to be caused by the lack of sunlight. Further, too little light can imply risks of working accidents. Too little or too much light can be stressfull and imply difficult working conditions in terms of exertion of the eye, headache etc. In using computers or other screens, light can imply bad visibility etc.

\section{Noise}

- What is the level of noise in the work place?

Noise can imply unpleasant working conditions as well as be damaging to the hearing capabilities of the employees. Too high a level of noise can cause hearing problems, tinnitus etc. 


\section{Temperature}

- Is the temperature at the work place high, low or shifting?

High and low working temperatures imply that employees can have difficulties regarding the general health state among the employees. Furthermore, it can cause bad working climate in terms of unpleasant conditions with too high, too low or changing work temperature.

\section{High Amount of Repetition in Motion}

- Does the work imply that the employees are exposed to a high amount of repetition in motion?

Repetition in motion can take many forms. One well-known example is that of the work carried out in large butcheries. Another example may be that of secretaries or other people typing on computers for many hours. A high amount of repetition in motion implies that employees risk physical attrition.

\section{Work Involves Simultaneous Lifting and Suboptimal Movement/Positioning}

Musculoskeletal complaints and disorders are the most common cause of sick-leave and disability pension in Norway. Pain in the neck, shoulders or upper back is the most prevalent musculoskeletal disorder and is experienced by two of five in the Norwegian working population on a monthly basis. Among these, nearly 60 per cent report that these complaints are wholly or partly related to their job. Pain in the lumbar or lower back and pain in the hips, legs and feet are also common symptoms. Between 40 and 60 per cent of the Norwegian working population with musculoskeletal complaints report that these wholly or partly are related to their job, but there are major differences between occupational groups (Source: Survey of living conditions, Statistics Norway 2009). Back pain is a common cause of sick leave and disability pension in Norway. Documented work related risk factors include work operations including simultaneous lifting and bending positions.

\section{Work Involves Static Loads}

Static loads include standing still or walking much in the same position, e.g. with arms raised. Static workloads on muscles have a welldocumented relation to muscle pain, back pain, neck pain, pain in the arms and shoulders, etc.

Pain in the neck, shoulders or upper back is the most prevalent musculoskeletal disorders and is experienced by two of five in the Norwegian working population on a monthly basis. Among these nearly 60 per cent report that these complaints are wholly or partly related to their job. Pain in the lumbar or lower back and pain in the hips, legs and feet 
are also common symptoms. Between 40 and 60 per cent of the Norwegian working population with musculoskeletal complaints report that these wholly or partly are related to their job, but there are major differences between occupational groups (Source: Survey of living conditions, Statistics Norway 2009).

Work factors related to musculoskeletal complaints and disorders have been reviewed in a recent report from the National institute of occupational health in Norway (Stami report 2008) showing that pain in the neck and shoulders are common, and can have many and complex causes, among these static loads of the neck muscles, especially working with upraised arms without support

\section{Production or Use of Certain Chemicals}

- Above normal exposure to certain chemicals (skin contact/ breathing/eye contact)?

If the work implies working with chemicals, this involves to a great deal a risk concerning the health of the employees. Chemicals can be both fatal and involve permanent external as well as internal injuries. Chemicals can cause short term illness but can also have long term effects for the health.

\section{Exposure to Smoke, Dust, Fumes (Skin Contact/Breathing/Eye Contact)}

- Does the work well-being include a risk of inhaling unhealthy particles etc. through the human airways?

Inhaling particles, dust, smoke etc. imply a variety of risks. This can have consequences for the general well-being and work satisfaction but can also imply the risk of the health of employees, regarding short term illness but also in the longer run concerning cancer or other airway diseases. Some jobs involve this exposure to a larger extent than other, e.g. in some production facilities or work in the traffic.

\section{Work Accident Risks In Terms of Using Technical Equipment and Machinery}

- Does the work include working with technical equipment and machinery which imply a general risk for work accidents?

Some jobs are performed in settings where there is a high risk of work accidents as a consequence of using technical machinery. This can imply risks of cuts and wounds and can in some incidents lead to amputation of body parts. 


\section{Work Includes Risk of Falling from Heights}

Construction workers are examples of personnel having a job with a large risk of falling from heights. Falling can be fatal or cause disabilities.

\section{Work Includes Traffic Risk}

- Does the work imply risk of traffic accidents?

Many jobs involve moving in traffic. Moving in traffic most of the day increases the risk of being part of a traffic accident. This involves many different jobs - bus driver, lorry driver, taxi driver, post man, police officer etc. Some of those have a larger risk concerning traffic accidents than others. Furthermore, there are jobs performed in the traffic - construction workers, road construction workers etc. working in the traffic. Traffic accidents evidently involve large risks of the health of employees. Furthermore, it involves a production loss if it occurs.

\subsection{Psychosocial Conditions}

Psychosocial conditions also constitute a central part of work well-being and affect employees' psychosocial and physical health. Here, the psychosocial indicators are tentatively divided into three categories, namely influence, demands, and work-reward balance and leadership. This section draws on and was informed by the collection of indicators across six countries made available courtesy to Aasnaes. Many of the indicators in this section coincide in topic with the indicators of "company practice". However, the indicators below should first and foremost measure how the psychosocial conditions are experienced by employees, whereas the indicators above in the company practices section are meant to measure what the company does do, and what it doesn't. Hence, the important difference is one of levels: Company practice is on the company level, whereas psychosocial conditions are here taken to be at the individual or employee level.

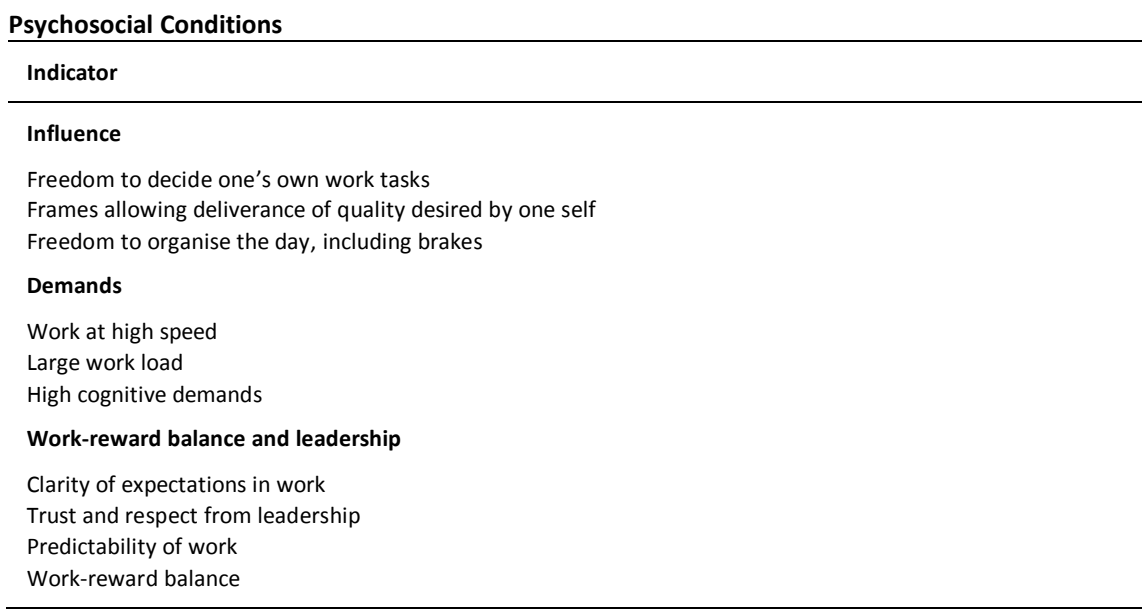

Source: DAMVAD and expert group, 2011. 


\section{Influence}

The indicators in this category are important as measures of the individual's ability to counter basic psychological imbalances, where desires and the way, a person would like the world to be is not in correspondence to the way, the real world is. Among important factors in countering imbalances are:

- Freedom to decide one's own work tasks

- Frames allowing deliverance of quality desired by one self

- Freedom to organise the day, including breakes

The freedom to decide, what tasks, one wants to work with is an obvious way to counter the basic psychological imbalance: If you can decide to work with different tasks, then (hopefully) you can decide to work with the work tasks that you desire.

If the frames, in which one's work is situated, do not allow deliverance of the quality that one desires, then this is an obvious source of a psychological imbalance. If the frames do allow for the quality that one desires, then that is a good starting point in countering imbalances.

The freedom to organise one's own day, including breaks, also has to do with the ability to affect and adapt the "real world" in order to make it correspond to the desired world - and thus avoid psychological imbalance.

\section{Demands}

High demands - qualitatively as well as quantitatively - are an obvious source affecting the psychosocial conditions at the work place. Important factors are:

- Work at high speed

- Large work loads

- High cognitive demands

High demands affect the psychosocial conditions at the work place because it puts individuals under pressure. Work at high speed, for instance, can instigate development of stress symptoms, because it increases the amount of resources the individual has to employ in order to overcome the work. This, in turn, increases the levels of certain hormones, etc. - in some instances into adverse levels, which can highly affect individuals' well-being.

\section{Work-Reward Balance and Leadership}

The work-reward balance is of great importance to the psychosocial conditions at the workplace. It is important, that individuals feel their work is rewarded in a manner, which is proportional to their efforts. 
Also, and in connection to this, it is important, that individuals feel that their efforts at the workplace are recognised.

Important factors are:

- Clarity of expectations in work

- Trust and respect from leadership

- Predictability of work

- Work-reward balance

Clarity of expectations is important, because unclear expectations make it difficult to manoeuvre and to predict what outcome is desired by management. This raises difficulties of receiving recognition, once the work tasks are completed, and it raises uncertainty of outcomes as well as rewards. Uncertainty can be a source of psychological imbalance.

Trust and respect from leadership is important for obvious reasons. Predictability of work is important, because it lowers uncertainty about when to work and how much - making it possible to predict periods with late hours, etc.

\subsection{Well-Being}

The work well-being indicators measure the "result"/output/effect in terms of the state of the workers' health and safety, broadly defined. This can be done on basis of two main categories of indicators:

- Fact-based indicators, that is, indicators measuring the state of the work well-being in an "objective" manner, as opposed to

- Self-reported indicators, or "subjective" measurement of the work well-being

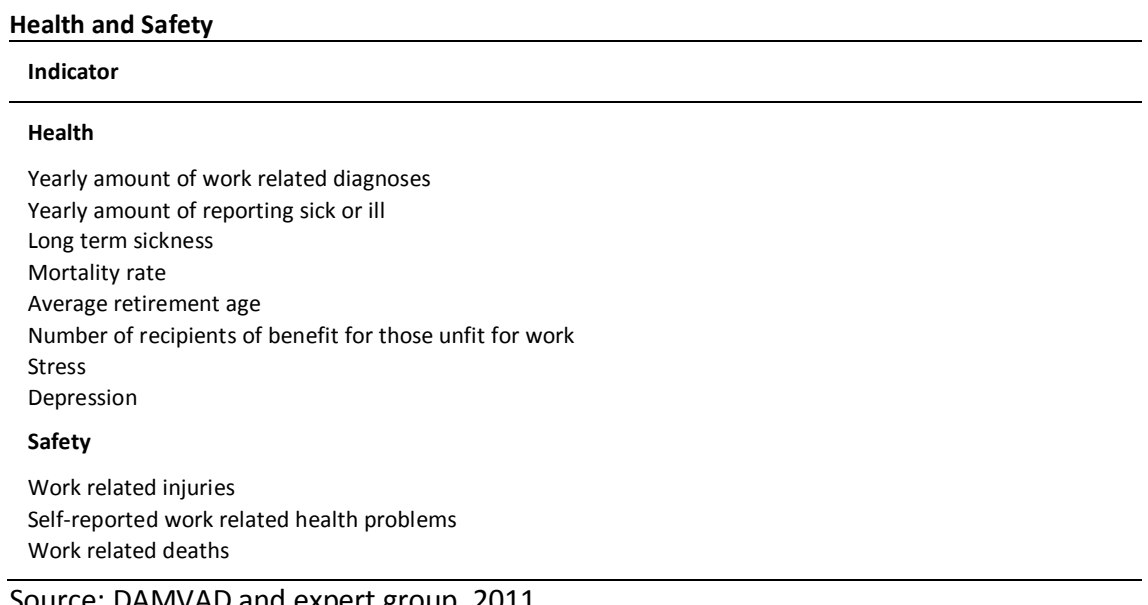




\section{Yearly Amount of Work Related Diagnoses}

- How many work related diagnoses per year in the company?

The number of work related diagnoses has an obvious connection to the state of the workers' health. Also, it will be a precise measure, because it rests upon the evaluation of workers by doctors, many of whom have years of experience in that field. However, it will also be a somewhat conservative measure: Typically, what is recognised as a work related illness - and hence which illnesses actually fall under the definition of "work related diagnoses" - is not necessarily exhaustive of what might be termed illnesses with relation to the work well-being.

\section{Yearly Amount of Reporting Sick or Ill}

- How many workers report sick or ill for how many days per year

The number of workers as well as the number of days may be interesting in respect to indicating work well-being caused illnesses. It could be hypothesised that typically, reporting sick or ill for shorter periods of time (i.e. 3-5 days) will not be related to work well-being. Longer periods of sickness or illness may indicate, however, that the work wellbeing affects the workers in question in adverse ways.

An argument opposing the use of this indicator is - to state the obvious - that not all illness or sickness relates in any way to the work wellbeing. However, the argument in favour of this indicator is, that there will be a tendency to higher levels and longer periods of illness and sickness when the work well-being provides adverse conditions than there will be, when the work well-being is better.

\section{Long Term Sickness}

- What is the number of employees away because of long term illnesses?

- How long are average periods of sickness?

The argument in favour of this indicator is that a large number of employees on sick leave in one company indicates a working environment, which supports workers in avoiding illness or sickness less well. This does not mean that there is a guarantee that a high number of employees away for longer terms due to sickness is related to, say, a very stressful working environment. However, it is a narrow thought that something somehow goes wrong in that company, and that it makes the employees sick. Further, this could also be true for a whole industry or sector. That is, if there is a high rate of workers away for prolonged periods of time in a sector (compared to other sectors), then that sector may pose a problem with regard to work well-being. 
In addition, the length of the periods, which employees are away because of illness may be taken as an indicator of how bad things are. If in one company, employees on sick leave are away for several months, this indicates a more hostile working environment compared to companies where the average lengths of sick leaves are, say, a few weeks.

\section{Mortality Rates}

- What is the mortality rate among workers in a company?

The mortality rate may be an indicator which is better used as an indicator of more general levels of work well-being (and other factors) in, say, a country or a region. This is because the mortality rate will be extremely low in most companies - and often not defined (i.e. no workers have died while employed in that company).

However, it may certainly be the case that larger corporations, as for instance large financial companies, law firms or ship builders may have a large enough group of employed people so as to have a well-defined mortality rate. In these instances, comparing the mortality rate of the company to that of the country as a whole will be a good indicator of factors affecting the workers in that particular company. This is because the mortality rate of the country as a whole already "contains" and reflects all of the factors affecting the workers but have nothing to do with the company - i.e., the difference in mortality rates must owe to factors in play in that company. This could also be true for a whole sector of companies - that is, working environment could be especially "deadly" in the ship building industry, for instance.

One pitfall in using this indicator is that mortality rates may be affected by a whole working life, whereas they are less likely to be affected by the job that "happened to be" the last one in a working life. This is to say, mortality rates may be better suited for measuring work wellbeings of a sector, rather than the work well-being of a company. Mortality rates may still tell us something about the work well-being in a company, though. If in one company, the mortality rate doubles one of the sector as a whole, then probably, this is not without connection to the work well-being in that specific company.

\section{Average Retirement Age}

- The average age of retirement

If, in a company, there is a hostile working environment, or the work can be characterised as one with a lot of heavy lifting and hard, physical work, it will possibly lead to many early retirements when compared to companies where this is not the case. That is because workers will be worn down and simply not capable of working for as many years as workers are in other businesses - or workers will seek to avoid the hostile (psychosocial) working environment, and retire when possible. Again, for this 
indicator, the average retirement age of the company must be compared to the average retirement age of the country (or region) as a whole, since obviously, old age retirement regulations and retirement plans will have an effect on the average age of retirement in any one given company. As for mortality rates, this indicator could be used for surveying the working environment in a whole industry or sector.

\section{Number of Recipients of Benefits for Those Unfit to Work}

The number of recipients of benefits for those unfit to work can be an indicator of the working environment in a company or a sector in so far as those recipients are former workers in that company or sector. If there is a high share of workers ending their career early by starting to receive benefits for those unfit to work - again comparatively - then this may indicate an adverse working environment.

\section{Work Related Injuries}

The number of work related injuries is an obvious indicator of the (physical) working environment. If there is a - comparatively - high level of work related injuries, it is probably the case that in this company, there is an adverse (physical) working environment. DK 2010: 4,435 fractures, 116 amputations (www.at.dk)

\section{Self-Reported Work-Related Health Problems}

This is obviously an indicator of the working environment, as workers are asked to report work-related health problems. However, as straightforward as it is, there are also some problems that must be addressed before using this indicator. These are the well-known criticisms of the use of survey questions in general, and its use in relation to strategic information in particular. Thus, work-related health problems may be understated by workers if this is perceived to be more opportunistic by the workers answering the survey. If the company management reads the survey, this may well be the case. Further, this may be the case even when surveys are answered anonymously - and even if management does not have the right to read out the results of that particular company.

\section{Number of Work Related Deaths}

- The number of deaths related to work

This indicator has a very clear and obvious connection to the working environment. However, it should be compared to that of the country as a whole in order for the researcher to be able to draw conclusions on the working environment of a particular firm - for much the same reasons as comparing the death rate to that of the country (or region) as a whole. One can argue, of course, that one work related death is one too many. 
However, if we wish to classify the working environment, then that has to be done relative to something else.

In Denmark 39 was killed in work related deaths in 2010 (www.at.dk)

\section{Stress}

- The number of employees with stress

Stress can come from many sources. It can be the result of demands at work which are perceived to be higher than what can be attained, or it can owe to a hostile working environment. In common, it could be said that individual perceptions of the surrounding conditions, challenges, and opportunities do not match individual goals and aspirations.

\section{Depression}

- Number of employees with a depression

This indicator may be self-reported or it could be fact-based, namely if it is considered to be the number of employees that have a depression diagnose. Obviously, workers could also be asked whether or not they have reported sick because of a depression (diagnosed or not). Depression is known to have a connection to (Stansfeld 2006, Bonde 2008):

- High job demands combined with low control and low social support

- Effort-reward imbalance

- Poor climate of cooperation ("team climate")

Hence, there is a strong relationship between depression and the psycho-social working environment. 



\section{Data Availability and Data Quality}

The Nordic experts have searched for national data regarding work wellbeing and work well-being practices. The indicator lists are organised in four groups corresponding to the four groups in the analytical model. The purpose is to test data availability. The availability and relevance of each of the indicators is described in detail in the appendix. This chapter gives an overview of the analytical possibilities by reporting overall grades given to the indicators on basis of the grading given by each of the countries in appendix A. The chapter is organised in order to reflect the indicator groups.

\subsection{Company Work Well-Being Practice}

A group of indicators is supposed to measure the general company practice with relevance for work well-being across the four Nordic countries. This group of indicators is in general available across the Nordic countries. However, there appears to be difficulties in Finland regarding linking the data to company performance. This makes it difficult to carry out analyses based on the indicators. The possible analyses will refer to descriptive statistics only and not measure impact on company performance.

Most of the indicators are furthermore available in Denmark, Norway, and Sweden. There are individual indicators not available in most of the countries.

Generally, many of the indicators are, however, based upon the perception of the employees, since the availability of factual register-based information is limited, and furthermore the information is only to a limited extend based upon factual information from the management. This implies a risk that the employees only refer to their own perception, based on their departmental whereabouts in the company, while practices may be different in other departments. On the other hand it is questionable whether the practices as described by management will be more accurate. In some of the questions, there are data from both management and employees. If a given sample covers employees as well as management from the same company, it makes it possible to do a validity check regarding the data. However, the possibilities to do this are expected to be limited.

It is possible to analyse this part of the model in Denmark, Norway, and Sweden. However, the analysis must be based on the fact that the 
information regarding the companies will mainly be defined by the employees. It constitutes a methodological issue whether this is acceptable. On the other hand, it is necessary to acknowledge that a great deal of the impact of work well-being is linked to the individual perception.

Some of the indicators regarding company work well-being practice are only to a limited extent covered in the Nordic countries. The data has to a great extend been covered in Denmark, making it possible to conduct analysis on Danish data. The Danish data are of a relatively good quality.

It does not appear possible to make benchmark and descriptive statistics across the Nordic countries with respect to all of the indicators regarding company work well-being practice.

In the table below presence of good data (A) for each indicator is marked with bold, while adequate (B) is marked with a italics and questionable (C) or no present data has got no marks.

\begin{tabular}{|c|c|c|c|c|c|}
\hline INDICATOR & DK & FI & No & SE & TOTAL \\
\hline Job control and influence & $\mathrm{k}$ & C & $\mathrm{C}$ & A & $\mathrm{C}$ \\
\hline Feedback & & C & $\mathrm{C}$ & $\mathrm{C}$ & $\mathrm{C}$ \\
\hline Reward systems and acknowledgement & $B$ & C & $\mathrm{C}$ & $\mathrm{C}$ & $\mathrm{C}$ \\
\hline Demands and expectations & C & C & $\mathrm{C}$ & A & C \\
\hline Flexible job descriptions & $B$ & $c$ & C & A & C \\
\hline Social support from management & $B$ & C & $\mathrm{C}$ & A & C \\
\hline Problem solving, dialogue oriented collaboration climate & $B$ & C & C & A & C \\
\hline Social support from colleagues & $B$ & $\mathrm{C}$ & $\mathrm{C}$ & A & $\mathrm{C}$ \\
\hline Clarity of roles & $B$ & C & $\mathrm{C}$ & $\mathrm{C}$ & C \\
\hline Work scheduling & $B$ & C & C & A & C \\
\hline Working communities / group work & & $\mathrm{C}$ & & A & $\mathrm{C}$ \\
\hline Evaluation tools & A & $c$ & $\mathrm{C}$ & $B$ & $c$ \\
\hline Personnel policy & $B$ & C & & & C \\
\hline Work well-being programs and plans & $B$ & $c$ & & & C \\
\hline Work well-being or safety organization & $B$ & C & & & C \\
\hline Certification in work well-being & & $c$ & & & \\
\hline General training and competence development & $B$ & C & $c$ & & $c$ \\
\hline Regular evaluation of training needs and wishes & & C & & & \\
\hline Training in work well-being & & $\mathrm{C}$ & & & \\
\hline Countering repetitive work and hard physical work & $B$ & & & & \\
\hline Ergonomics and design & $B$ & & & & \\
\hline $\begin{array}{l}\text { Specific action plans and action concerning noise, chemicals, indoor } \\
\text { climate etc. }\end{array}$ & $B$ & & & & \\
\hline Preventive actions regarding work accidents & $B$ & C & & & C \\
\hline Physical exercise & $B$ & C & & & C \\
\hline Health checks & $B$ & C & C & & C \\
\hline Rehabilitation courses, medical treatment, intoxicant programs etc. & $B$ & C & & & C \\
\hline
\end{tabular}

Comment: Good data (A) for each indicator is marked with bold, while adequate (B) is marked with italics and questionable (C) or no present data has got no marks.

Source: DAMVAD and expert group, 2011

\subsection{Indicators Regarding Physical Conditions and Exposures}

The third group of indicators reflect the specific physical conditions for employees in a company.

This group of indicators is in general available across the Nordic countries. However, there appears to be difficulties in Finland regarding 
linking the data to company performance and in Norway with the general availability of some of the indicators. This makes it difficult to carry out analyses based on all of the indicators for Norway and Finland. For Finland, where it is not possible to link data, there might still be some descriptive statistics that may provide valid information.

There are only two indicators where data is not available in one or more of the countries and there is a high data as such.

The indicators are based on perceptions by the workers and this has some advantages as well as disadvantages. The advantages are that it is the workers that experience the physical conditions and exposures in their daily work and as such has an extensive knowledge of what they encounter. There is, however, no guarantee that the assessments from the workers are valid for all the workers as there might be a bias towards e.g. production workers with more exposure than administrative workers.

This makes it possible to analyse the model for Denmark and Sweden bearing in mind the fact that the input to the model is based on assessments of the employees.

Physical Conditions and Exposures

\begin{tabular}{|c|c|c|c|c|c|}
\hline INDICATOR & DK & FI & NO & SE & TOTAL \\
\hline Light & A & C & $B$ & $B$ & $B$ \\
\hline Noise & A & C & $B$ & $B$ & $B$ \\
\hline Temperature & A & c & A & $B$ & $B$ \\
\hline High amount of repetition in motion & A & c & $B$ & $B$ & $B$ \\
\hline $\begin{array}{l}\text { Work involves simultaneous lifting and suboptimal movement/ } \\
\text { positioning }\end{array}$ & A & C & $B$ & $B$ & $B$ \\
\hline Work involves static loads & A & C & $B$ & $B$ & C \\
\hline Production or use of certain chemicals & A & C & & $B$ & C \\
\hline Exposure to smoke, dust, fumes (skin contact/breathing/eye contact) & A & C & c & $B$ & C \\
\hline $\begin{array}{l}\text { Work accident risks in terms of using technical equipment and } \\
\text { machinery }\end{array}$ & $B$ & c & C & $B$ & c \\
\hline Work includes risk of falling from heights & A & C & & & C \\
\hline Work includes traffic risk & $B$ & B & C & $B$ & c \\
\hline
\end{tabular}

Comment: Good data (A) for each indicator is marked bold, while adequate (B) is marked with italics and questionable $(C)$ or no present data has got no marks.

Source: DAMVAD and expert group 2011

\subsection{Indicators Regarding Psychosocial Conditions}

The fourth group of indicators reflect the psychosocial conditions in the work place. This group of indicators is mainly indicators of an individual perception of how one is affected. Here, it therefore is highly appropriate with individual self-evaluation.

The psychosocial conditions at the workplace are to a great extend covered in both Denmark and Sweden. Norway states that it is not possible to link Norwegian individual data to companies, however. This needs to be clarified. If this is possible, it gives great opportunities, besides Finland. Most of the issues are covered in Sweden, where they also have a high quality, and in Denmark with adequate quality. The same 
appears to be true in Norway if it is possible to link the individual data to the company data. Furthermore, the Swedish and Danish data are, in general, able to link company performance and company business register information. Furthermore, the main part of the indicators seems to have responses from both employees and employers.

Across the Nordic countries, it appears as if it is possible to benchmark and analyse descriptive statistics of several of the indicators.

\begin{tabular}{lccccc} 
Psychosocial conditions & & & & & \\
\hline INDICATOR & DK & FI & NO & SE & TOTAL \\
\hline Freedom to decide one's own work tasks & B & C & C & B & C \\
Frames allowing deliverance of quality desired by one self & B & & & & C \\
Freedom to organise the day, including brakes & & C & C & A & C \\
Work at high speed & B & C & C & B & C \\
Large work loads & A & & C & A & B \\
High cognitive demands & B & C & C & B & C \\
Clarity of expectations in work & B & C & & A & B \\
Contradiction demands & B & & C & & C \\
Trust and respect from leadership & B & C & C & A & B \\
Trust and respect from colleagues & & & & A & C \\
Predictability of work & B & & C & C \\
Motivation & & & & A & C \\
Work-reward balance & & C & C & A & C
\end{tabular}

Comment: Good data (A) for each indicator is marked with bold, while adequate (B) is marked with italics and questionable $(C)$ or no present data has got no marks.

Source: DAMVAD and expert group, 2011

\subsection{Indicators Regarding Well-Being}

The indicators regarding well-being are in general covered by the Nordic countries but it is almost exclusively in Denmark and in Sweden that the data is of a sufficient quality. However, the issue regarding Finnish and Norwegian data refers to the linking possibilities, since there are data in both countries.

The data which is covered by Denmark and Sweden are, however, not the same except for six indicators which will have to form the basis for any comparable analysis.

For these six indicators analyses can be made but it is important to bear in mind that the well-being is not necessarily related to the work place in cases where there are or are not reported illnesses. Furthermore the qualities of people to assess their own well-being in a common and consistent manner are limited and as such the quality of much of the data will be conditioned by this.

The overall assessment is, however, that the analysis can be carried out for Denmark and Sweden given the similarities in the covered questions. If the Norwegian and Finnish data were linkable to company performance, the data quality is supposed to be quite high. 


\begin{tabular}{llllll} 
Well-Being & & & & & \\
\hline INDICATOR & DK & FI & NO & SE & TOTAL \\
\hline Yearly amount of work related diagnoses & B & C & C & A & B \\
Yearly amount of reporting sick or ill & A & C & B & A & A \\
Short term sickness (new indicator Ulf) & & & & A & C \\
Long term sickness & B & C & B & A & B \\
Mortality rates & A & C & & & C \\
Average retirement age & A & C & & & C \\
Number of recipients of benefits for those unfit to work & A & C & C & & C \\
Work related injuries & B & C & C & & C \\
Self-reported work-related health problems & B & C & C & A & C \\
Number of work related deaths & & C & C & A & C \\
Stress & C & C & C & A & C \\
Depression & C & C & C & A & C
\end{tabular}

Comment: Good data (A) for each indicator is marked bold, while adequate (B) is marked with italics and questionable $(C)$ or no present data has got no marks.

Source: DAMVAD and expert group, 2011.

\subsection{General Data Quality Assessment}

The chart below summaries the results of the analysis in the five indicator groups. The chart shows where data is available for econometric modelling and impact assessments.

The overall picture is that there are analytical possibilities across the Nordic countries. Especially it looks as if, the Danish and Swedish data are applicable to a large extend in most of the areas. It also seems as if the Norwegian data might be applicable, if they are able to be linked to the companies. This is the case in many other areas, where DAMVAD has worked with Norwegian micro data. But this needs to be finally clarified. The feasibility study of phase 2 of the proposed project will do so. The same might be true for Finland. However, DAMVAD has no experience in working with Finnish data.

Across most part of the indicator groups, it will be possible to make some benchmarking, since this does not call for a linking opportunity to company performance indicators.

However, regarding company work well-being practice, the data is very limited across the countries. This implies that this part of the analysis may primarily be possible to carry out for Danish work places. 


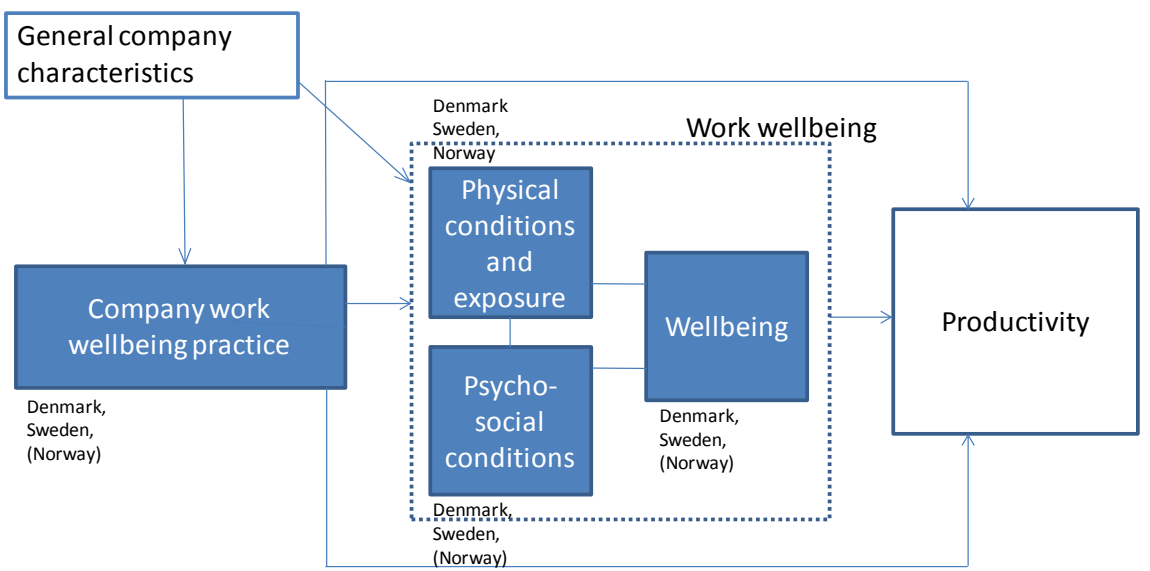

Chart 5.1. Data avaliable for econometric analysis

Source: DAMVAD and expert group 2011.

Most of the data is based on self-evaluation and reporting across the Nordic countries. Hence, the personal perception among the employees regarding work well-being will be the most common source of information. In some cases, especially in Denmark, the employer will be a source of information as well. Finally, the group of indicators regarding well-being in all the reported countries are to a large extend based on register data, making it highly comparable.

There appears to be a large degree of cross-country comparability in terms of the formulation of the questions.

To summarise, it appears to be possible to analyse the relationship between work well-being and productivity in the Nordic countries. However, it is mostly possible for Danish and Swedish data.

Furthermore, it is difficult on a Nordic level to analyse company level work well-being practice. Finally, the analysis will primarily be based on individual perceptions from employees, and, to a lesser extent, perceptions from workplaces, and to a minor extent based on registry data. 


\section{References}

Ahonen \& Hussi (2007): «Work ability and human resource reporting - the Finnish experience.» In Johanson, U., G. Ahonen, R. Roslender (eds.) 2007: «Work, health and management control.» Thomson Fakta. Stockholm.

Ahonen (2008): «Inspired by Knowledge in Organisations.» Publications of the Swedish School of Economics and Business Administration. Nr. 182. Helsinki.

Alexanderson, K., A. Norlund (ed.): «Sickness absence - causes, consequences and practices. A systematic literature review by the Swedish Council on Technology Assessment in Health Care.» Scandinavian Journal of Public Health Supplement 2004; 63: 12-30.

Anttonen et al. (2008): «Well-being at work - New innovations and practices.» Finnish Institute of Occupational Health. Helsinki 2008.

Arbejdstilsynet (2010): Fremtidens arbejdsmiljø 2020: Copenhagen.

Aura O., G. Ahonen, J. Ilmarinen (2010): «Strategic Wellness Management in Finland - the first national survey of the management of employee well-being.» Journal of Occupational and Environmental Medicine Vol. 52 No 12, p. 1145-1282.

Becker, Brian E. and Mark A. Huselid (1998): «High Performance Work Systems and Firm Performance: A Synthesis of Research and Managerial Implications.» Research in Personnel and Human Resources Management, 16:53-101.

Bonde JP. (2008): «Psychosocial factors at work and risk of depression: a systematic review of the epidemiological evidence.» Occupational and Environmental Medicine 65(7):438-45.

Hörte, S.Å. (2009): «Arbete, arbetsmiljö och arbetsmiljöarbete. I Perspektiv på arbetsmiljöarbete.» Red Hörte, S.Å. och Christmansson, M. Högskolan Halmstad.

Johanson, U., M. Mårtensson, and M. Skoog, (2001): «Measuring to understand intangible performance drivers.» European Accounting Review, 10:3, pp. 1-31

Kristensen, Tage (2010): «Trivsel og produktivitet - to sider af samme sag.» HK Danmark: Copenhagen.

Lazarus, Richard S. (1999): «Stress and emotion.» Freedom Association Books, London.

Näsman, O., J. Ilmarinen (1999): «Metal-Age: A process for improving well-being and total productivity.» Experimental Aging Research Vol 25 No. 4 USA.

STAMI-rapport. Årgang 9, nr 22 (2008): «Arbeid som årsak til muskelskjelettlidelser. Kunnskapsstatus.»

Stansfeld, S., B. Candy (2006): «Psychosocial work environment and mental health--a meta-analytic review.» Scandinavian Journal of Work and Environmental Health Vol. 32(6):443-62.

Van der Mer, P. and K. Ringdal (2009): «Personnel Review. Farnborough.» Vol. 38 No 5, pp. 526. 



\section{Sammenfatning}

Denne rapport indeholder en indikatormanual til måling af arbejdsmiljø og trivsel. Dermed fuldender rapporten fase 1 af et projekt i tre faser om den mulige sammenhæng mellem arbejdsmiljø, trivsel og produktivitet. Dette forhold - mellem trivsel og produktivitet - er blevet undersøgt før. Men der er - ifølge forfatternes kendskab - ikke tidligere gennemført undersøgelser af sammenhængen med brug af grundig økonometrisk analyse, på tværs af de nordiske lande. Denne indikatormanual er et første skridt på vejen til at gennemføre en sådan analyse.

Indikatormanualen skitserer og definerer et fælles nordisk koncept for arbejdsmiljø, trivsel, arbejdsevne og andre begreber i relation til dette område. Den udpeger endvidere indikatorer til måling af de forskellige aspekter af arbejdsmiljøet. Endelig præsenterer rapporten datakilder for hver af de identificerede indikatorer fra de fire lande Finland, Sverige, Norge og Danmark.

Datakilderne er vurderet i henhold til tilgængeligheden af data, relevans, tilgængelighed, nøjagtighed og sammenlignelighed på tværs af de fire lande. Manualen viser, at selv om nogle af de indikatorer, som kunne være nyttige i en fuldstændig beskrivelse af arbejdsmiljø og trivsel, ikke kan måles i alle de ovennævnte lande, synes der at være et godt grundlag for grundige økonometriske analyser af forholdet mellem arbejdsmiljø, trivsel og produktivitet.

Projektet, der finansieres af Nordisk Ministerråd, er gennemført af en gruppe eksperter, bestående af

- Otto Melchior Poulsen, Det Nationale Forskningscenter for Arbejdsmiljø (Danmark)

- Guy Ahonen, Työterveyslaitos / Finnish Institute of Occupational Health (FIOH), Finland

- Steinar Asnaess, STAMI, Norge

- Ulf Johansson professor ved Mälardalen Universitet, Sverige

i samarbejde med det forskningsbaserede konsulentfirma DAMVAD i København, Danmark 



\section{Appendix A: Data Availability and Data Quality}

This data appendix prepares the ground for the analyses of the hypothesised relationship in the indicator manual, and other analyses in the area of working environment and productivity. As such, it is quite lengthy. This, however, owes to the fact that it was found necessary at the outset - and has, indeed, proven to be necessary - to go systematically and thoroughly through the different sources of data in the Nordic countries in order to produce a data appendix, which was comprehensive to an extent that allows empirical analysis to be carried out based on the manual.

There are still indicators, where clarification of the possible data sources in the Nordic countries will be of importance. This will be handled in the proposed phase 2 of the project, which constitutes a feasibility study with regards to data collection with respect to the indicators in the manual.

\subsection{Testing Data Availability}

An important element in the project about work-well-being and productivity is to test data availability across the Nordic countries and find out whether these data are comparable with each other on each of the identified theoretical indicators.

The indicator-data will be identified by each of the participants and tested according to three concepts:

- Relevance

- Accuracy

- Availability

For each of the three testing concepts the indicators will be given a grade:

- $\mathrm{A}=$ Very good.

- $\mathrm{B}=$ Good.

- $\mathrm{C}=$ Acceptable. 


\section{Relevance}

A relevant indicator is close to the theoretical indicator, it is intended to measure. Each of the indicators are to be given a grade - A or B. A signifies a direct measure. B signifies a proxy measure.

\section{Accuracy}

The accuracy of an indicator is the degree to which the indicator correctly estimates or describes the quantities or characteristics it is designed to measure. Accuracy has two dimensions: Data collection method and degree of cross-country standardisation:

\begin{tabular}{|c|c|c|c|c|}
\hline $\begin{array}{l}\text { Data collection } \\
\text { method }\end{array}$ & $\begin{array}{l}\text { National statistical } \\
\text { offices, register data }\end{array}$ & $\begin{array}{l}\text { Surveys about perception of } \\
\text { work environment and self- } \\
\text { evaluation to employees }\end{array}$ & $\begin{array}{l}\text { Fact-based } \\
\text { surveys }\end{array}$ & $\begin{array}{l}\text { Opinion-based } \\
\text { survey }\end{array}$ \\
\hline Mark & A & A & B & C \\
\hline
\end{tabular}

Source: DAMVAD and expert group, 2011.

The following element will be evaluated by DAMVAD when all of the indicators have been reported:

\begin{tabular}{llll} 
Accuracy & Fully comparable & $\begin{array}{l}\text { Comparable to some } \\
\text { extent } \\
\text { comparable }\end{array}$ & $\begin{array}{l}\text { Comparable to } \\
\text { minor extent }\end{array}$ \\
Mark & A & B & C \\
\hline
\end{tabular}

Source: DAMVAD and expert group, 2011.

\section{Availability}

The concept of availability relates to the accessibility of a given indicator in various countries and for a given time frame.

\begin{tabular}{llll} 
Availability & & \\
\hline $\begin{array}{l}\text { The number of Nordic countries } \\
\text { where the indicator is present }\end{array}$ & At least 4 & 3 & C \\
Mark & A & B & \\
\hline & Collected each year & $\begin{array}{l}\text { Collected every 2-3 } \\
\text { years }\end{array}$ & $\begin{array}{l}\text { Collected every 4-5 } \\
\text { years or less }\end{array}$ \\
\hline Mark & A & B & C
\end{tabular}

Source: DAMVAD and expert group, 2011.

\section{The "Overall" Score}

The overall grade is given based on how well the given indicator performed on the previously mentioned quality dimensions. The grades have the following meaning: 
- $\mathrm{A}=$ Good: At least 3 A's and no C's

- $\mathrm{B}=$ Acceptable: At least $2 \mathrm{~A}$ 's and max one $\mathrm{C}$

- $\mathrm{C}=$ Questionable: Less than 2 A's or more than one C OR linking possibilities is given a $\mathrm{C}$

\begin{tabular}{llll} 
Scores & & & \\
\hline Name of indicator & Good & Acceptable & Questionable \\
Indicator & A & B & C
\end{tabular}

Source: DAMVAD and expert group, 2011.

\subsection{Indicators Regarding Company Work Well-Being Practice}

The physical and psychosocial well-being of the employee is affected by the way the company functions in general. This includes a lot of different aspects such as:

- organisation of work

- organisation of work hours

- individual influence

- the demand and work load

- supervisory practises

- culture and social support

These factors influence the work well-being of the employee whether they are subject to deliberate work well-being actions and effort by the work place or not. Some of the factors may be adjusted easily as a consequence of a work well-being action while others can be more difficult to adjust.

Some abbreviations are used in the text and tables below to describe the data in the four countries. The abbreviations are explained in table 7.1.

\begin{tabular}{|c|c|c|}
\hline Country & $\begin{array}{l}\text { Abbrevia- } \\
\text { tion }\end{array}$ & Explanation \\
\hline \multirow[t]{12}{*}{ Finland } & EWCS & European Working Conditions Survey. European Working Conditions Observatory \\
\hline & ECS & European Company Survey, Eurofound \\
\hline & MEADOW & Measuring the dynamics of organisations and work. Project, in preparation. CEE \\
\hline & EODS & European Occupational Disease Statistics \\
\hline & WHS & Work \& Health Survey, Finland, FIOH, (Työ ja Terveys), evry 3 years \\
\hline & WCB & Työolobarometri (Working Condition Barometer), Finland, MOL, annual \\
\hline & SWBS & Strategic Well-being Survey, Excenta \& FIOH, Finland, annual \\
\hline & LFS & Labour Force Survey, Statistics Finland \\
\hline & SSI & Statistics of The Social Insurance Institution of Finland, Finland (Kela) \\
\hline & SF & Statistics Finland \\
\hline & ETK & Eläketurvakeskus (The Finnish Centre for Pensions, Finland) \\
\hline & TVL & Accident statistics, Tapaturmavakuutuslaitosten Liitto, Finland, Annual \\
\hline \multirow[t]{2}{*}{ Norway } & LKU & Level of living conditions survey \\
\hline & SSB & Statistics Norway \\
\hline \multirow[t]{2}{*}{ Sweden } & WES & $\begin{array}{l}\text { The Swedish Work Environment Survey. Investigates employee perceptions every } \\
\text { second year. }\end{array}$ \\
\hline & SCB & Statistics Sweden \\
\hline
\end{tabular}




\begin{tabular}{|c|c|c|}
\hline Country & $\begin{array}{l}\text { Abbrevia- } \\
\text { tion }\end{array}$ & Explanation \\
\hline & OWE & $\begin{array}{l}\text { A part of the WES. It contains questions on systematic work environment directed } \\
\text { towards managers, safety delegates or members of work environment committees. }\end{array}$ \\
\hline & QWES & $\begin{array}{l}\text { A part of the WES. SCB and Swedish Work Environment Authority. It contains } \\
\text { questions on systematic work environment directed towards safety delegates. }\end{array}$ \\
\hline & $\mathrm{QOH}$ & $\begin{array}{l}\text { A part of WES. SCB and Swedish Work Environment Authority. It contains questions } \\
\text { concerning occupational health. }\end{array}$ \\
\hline & MED & The health and medical care register. \\
\hline & OAC & $\begin{array}{l}\text { Occupational accidents and workrelated diseases. SCB and Swedish Work Environ- } \\
\text { ment Authority. }\end{array}$ \\
\hline & LISA & $\begin{array}{l}\text { Refers to a longitudinal integrated database addressing labour market as well as } \\
\text { disease statistics. }\end{array}$ \\
\hline & ECQ & $\begin{array}{l}\text { Refers to a questionnaire that has been used annually since more than } 20 \text { years be } \\
\text { a big Swedish firm. A similar questionnaire is used for employee surveys in many } \\
\text { other big Swedish companies. This is the second most used source in the text } \\
\text { bellow. No linking possibilities }\end{array}$ \\
\hline \multirow[t]{3}{*}{ Denmark } & NAK & $\begin{array}{l}\text { Den Nationale Arbejdsmiljøkohorte/The National Working Environment Cohort. } \\
\text { Survey data collected every five years. Employees are surveyed. }\end{array}$ \\
\hline & VOV & $\begin{array}{l}\text { Overvågning af virksomhedernes forebyggende arbejdsmiljøarbejde/Surveillance of } \\
\text { the preventive working environment efforts of enterprises. Those responsible for } \\
\text { working environment and employee representatives are surveyed. Every five years. }\end{array}$ \\
\hline & DREAM & Data collected by the Danish National Labour Market Authority. \\
\hline
\end{tabular}

Source: DAMVAD and expert group, 2011.

\subsubsection{Job Control And Influence}

A general and important issue across the work well-being literature is to which extend the employees have control over their own tasks. Therefore it is important to evaluate if and how companies aim at empowering the employees, and to what extent they give the autonomy and predictability in the work effort.

\section{Denmark}

Description: Is not covered directly in NAK or VOV. The closest we can get is:

- Do you influence your work tasks?

NAK 2005-135; 9:

- Do you participate in the organization of your work?

NAK 2005-131 og NAK 2010-20:

- What actions have the company taken in order to increase employee influence regarding their working condition within the last three years?

V0V2006-41

\section{Finland}

Description:

- ESWC: Q51, D and E

WCB - Only available in Finnish.

WHS - Only available in Finnish. 


\section{Norway}

Description: Level of living conditions survey - working environment (LKU):

- To what extent are you free to decide your own tasks?

- To what extent are you free to decide how to go about doing your work?

- Are you free to choose when to take a break from your work; e.g. to stretch your legs or take a break in some other way?

- To what extent can you influence decisions that are important to your work?

- To what extend can you decide the pace which your work?

\section{Sweden}

No further remarks.

\begin{tabular}{|c|c|c|c|c|c|}
\hline & DK & FI & NO & SE & Total \\
\hline Overall grade & & & & & $C$ \\
\hline 1. Relevance & A & B & B & B & C \\
\hline 2. Accuracy & A & A & A & A & A \\
\hline $\begin{array}{l}\text { 2. Cross-country } \\
\text { comparable }\end{array}$ & & & & & B \\
\hline $\begin{array}{l}\text { 3. Availability } \\
\text { across countries }\end{array}$ & & & & & A \\
\hline $\begin{array}{l}\text { 3. Availability } \\
\text { over time }\end{array}$ & C & $A-C$ & B & B & C \\
\hline $\begin{array}{l}\text { Linking } \\
\text { possibility }\end{array}$ & A & No & $\begin{array}{l}\text { C (link to persons, } \\
\text { not companies) }\end{array}$ & WES: A & \\
\hline $\begin{array}{l}\text { Source and } \\
\text { ownership }\end{array}$ & $\begin{array}{l}\text { NAK, National } \\
\text { Research centre } \\
\text { for the Working } \\
\text { Environment, VOV, } \\
\text { National Research } \\
\text { centre for the } \\
\text { Working Environ- } \\
\text { ment }\end{array}$ & $\begin{array}{l}\text { ESWC: European } \\
\text { Survey working } \\
\text { Conditions } \\
\text { WHS: Work \& Health } \\
\text { Survey, Finland, } \\
\text { FIOH, (Työ ja Ter- } \\
\text { veys), evry } 3 \text { years } \\
\text { WCB: Työolobaro- } \\
\text { metri (Working } \\
\text { Condition Barome- } \\
\text { ter), Finland, MOL, } \\
\text { annual }\end{array}$ & $\begin{array}{l}\text { Norwegian level } \\
\text { of living condition } \\
\text { survey - working } \\
\text { environment, SSB }\end{array}$ & $\begin{array}{l}\text { WES: The Swe- } \\
\text { dish Work } \\
\text { Environment } \\
\text { Survey. SCB and } \\
\text { Swedish Work } \\
\text { Environment } \\
\text { Authority }\end{array}$ & \\
\hline Accessible data? & Yes & Yes & Yes & Yes & $A$ \\
\hline
\end{tabular}

Source: DAMVAD and expert group, 2011. 


\subsubsection{Feedback}

Feedback is an important part of the psychological work environment. Feedback from managers and management is a way for employees to learn about and improve their performance as well as a way to get information about their job situation, future etc.

\section{Denmark}

Description: Is not covered by NAK or VOV.

\section{Finland}

Description:

- Does the management give regular and fair feedback to employees? EWCS: Q58:A

\section{Norway}

Description: Level of living conditions survey - working environment:

- Does the management give regular and fair feedback to employees?

- If you need it, how often can you get the support and help of your immediate superior with your work?

- How well does the following description fit your immediate superior? Your immediate superior treats employees with trust and respect?

- Do you get feedback from your superiors on how you have performed your work?

- Does your immediate superior treat employees fairly and impartially?

- Does your immediate superior value your achievements at work?

\section{Sweden}

Description:

- Have you had a performance appraisal with your manager within the past 12 months? ECQ

- If you have had a performance appraisal with your manager within the past 12 months

- What was the outcome of your discussion?

a) I received feedback on my work performance

b) I talked about my view on the leadership of my manager

c) We discussed my development opportunities

d) I gave my manager information about how I view the organization

e) Together we formulated concrete goals regarding my development for the 12 upcoming months

f) We always follow up the activities we agree on ECQ 


\begin{tabular}{|c|c|c|c|c|c|}
\hline & DK & $\mathbf{F I}$ & NO & SE & Total \\
\hline Overall grade & & & & & C \\
\hline 1. Relevance & $\mathrm{N} / \mathrm{A}$ & B & A & B & C \\
\hline 2. Accuracy & $\mathrm{N} / \mathrm{A}$ & A & A & $A$ & A \\
\hline 2. Cross-country comparable & & & & & B \\
\hline 3. Availability across countries & & & & & B \\
\hline 3. Availability over time & $\mathrm{N} / \mathrm{A}$ & C & B & A & C \\
\hline Linking possibility & No & No & No & No & c \\
\hline Source and ownership & & $\begin{array}{l}\text { EWCS: European } \\
\text { Working Conditions } \\
\text { Survey }\end{array}$ & $\begin{array}{l}\text { Norwegian level of living } \\
\text { condition survey - work- } \\
\text { ing environment, SSB }\end{array}$ & ECQ & \\
\hline Accessible data? & No & Yes & Yes & Yes & B \\
\hline
\end{tabular}

Source: DAMVAD and expert group, 2011.

\subsubsection{Reward Systems and Acknowledgement}

Across Denmark, Norway, Sweden and Finland, given an appropriate and fair awards related to the results of the employee is stated as important. This is related to and can be a specific way of acknowledgement of results from the management, which is also an important factor regarding the psychosocial work environment.

\section{Denmark}

Description: What is meant by "reward appropriately" seems rather unclear. It is neither covered directly in NAK or VOV.

- Are your efforts on the job being acknowledged and appreciated by the management?

NAK2005-141; 1 AND NAK2010-27; 1:

\section{Finland}

Description:

- Does the company reward the employees appropriately in accordance with their efforts?

EWCS: Q17

\section{Norway}

Description: Level of living conditions survey - working environment:

- Does the company reward the employees appropriately in accordance with their efforts?

- To what extent do you agree or disagree with the following statement? My salary is appropriate to my efforts and performance at work 
- To what extent do you agree or disagree with the following statement? In relation to my efforts and performance, I get the respect and recognition that I deserve at work.

\section{Sweden}

Description:

- Have you had a salary discussion with your manager in the last twelve months? ECQ

\begin{tabular}{|c|c|c|c|c|c|}
\hline & DK & FI & NO & SW & Total \\
\hline Overall grade & & & & & C \\
\hline 1. Relevance & A & B & A & B & B \\
\hline 2. Accuracy & A & A & A & A & A \\
\hline $\begin{array}{l}\text { 2. Cross-country } \\
\text { comparable }\end{array}$ & & & & & B \\
\hline $\begin{array}{l}\text { 3. Availability } \\
\text { across countries }\end{array}$ & & & & & A \\
\hline $\begin{array}{l}\text { 3. Availability over } \\
\text { time }\end{array}$ & C & C & B & A & C \\
\hline Linking possibility & A & No & No & No & C \\
\hline $\begin{array}{l}\text { Source and } \\
\text { ownership }\end{array}$ & $\begin{array}{l}\text { NAK, National Research } \\
\text { centre for the Working } \\
\text { Environment, } \\
\text { VOV, National Research } \\
\text { centre for the Working } \\
\text { Environment }\end{array}$ & $\begin{array}{l}\text { EWCS: Europe- } \\
\text { an Working } \\
\text { Conditions } \\
\text { Survey }\end{array}$ & $\begin{array}{l}\text { Norwegian level } \\
\text { of living condition } \\
\text { survey - working } \\
\text { environment, SSB }\end{array}$ & ECQ & \\
\hline Accessible data? & Yes & Yes & Yes & Yes & A \\
\hline
\end{tabular}

Source: DAMVAD and expert group, 2011.

\subsubsection{Demands and Expectations}

Demands and expectations are important factors for work well-being. The sense of being able to deliver what is expected is closely related to expectations regarding job security as well as hopes regarding wage and career potential. Thus, high and unrealistic expectations regarding effort increase uncertainty for the employee.

\section{Denmark}

Description: NAK does not contain questions regarding whether the employee experiences demands and expectations as reasonable. The questions about demands in NAK are generally more specific (e.g. a demand for higher working pace) 


\section{Finland}

Description:

- Are the demands and expectations towards the employee reasonable?

EWCS: Q42, Q46, Q60

\section{Norway}

Description: There are several questions tapping "job demands", but there are no measures of whether or not the demands or expectations are reasonable.

Quantitative demands

- How often do you have to work at a fast pace?

- How well does the following description fit your current job? ... There is normally not time to perform tasks properly.

- How often do you have too much to do?

- Do you sometimes have so much to do that you have to miss lunch, work longer than your normal working hours or take work home with you?

Emotional demands

- In your work, to what extent do you need to conceal negative feelings such as anger, irritation, frustration and so on for customers, clients or other people who are not employed at your workplace?

- In your work, to what extent do you need to deal with strong feelings such as sorrow, anger, desperation, frustration and so on from customers, clients or other people who are not employed at your workplace

Level of living conditions survey - working environment:

- Are the demands and expectations towards the employee reasonable?

\section{Sweden}

Description:

- Is it possible for you to set your own work tempo? WES

- Is your work sometimes so stressful that you do not have time to talk or even think of anything other than work? WES

- Does your work require your undivided attention and concentration? WES 
- Do you sometimes have so much work to do that you have to skip lunch, work late, or take work home with you?

WES

- In your job do you ever come into contact with people who are seriously ill or people with serious problems?

WES

- How do you experience your work? Far too much to do WES

- How do you experience your work? Tasks too difficult WES

- How do you experience your work? Mentally stressful work WES

\begin{tabular}{|c|c|c|c|c|c|}
\hline & DK & $\mathrm{FI}$ & NO & sw & Total \\
\hline Overall grade & & & & & C \\
\hline 1. Relevance & N/A & B & B & B & C \\
\hline 2. Accuracy & N/A & A & A & A & A \\
\hline $\begin{array}{l}\text { 2. Cross-country } \\
\text { comparable }\end{array}$ & & & & & B \\
\hline $\begin{array}{l}\text { 3. Availability across } \\
\text { countries }\end{array}$ & & & & & B \\
\hline $\begin{array}{l}\text { 3. Availability over } \\
\text { time }\end{array}$ & N/A & C & B & B, WES & C \\
\hline Linking possibility & No & No & No & WES: A & C \\
\hline $\begin{array}{l}\text { Source and owner- } \\
\text { ship }\end{array}$ & N/A & $\begin{array}{l}\text { EWCS: Euro- } \\
\text { pean Working } \\
\text { Conditions } \\
\text { Survey }\end{array}$ & $\begin{array}{l}\text { Norwegian level of } \\
\text { living condition } \\
\text { survey - working } \\
\text { environment, SSB }\end{array}$ & $\begin{array}{l}\text { WES: The Swedish } \\
\text { Work Environment } \\
\text { Survey. SCB and } \\
\text { Swedish Work Envi- } \\
\text { ronment Authority }\end{array}$ & \\
\hline Accessible data? & No & Yes & Yes & Yes & B \\
\hline
\end{tabular}

Source: DAMVAD and expert group, 2011.

\subsubsection{Flexible Job Descriptions}

An aspect closely related to control over work tasks as well as influence and repetitive work is whether companies have flexible job descriptions for employees. This enables for job rotation, professional development, influence on daily tasks, etc. (Ahonen, 2008).

\section{Denmark}

Description: Denmark is not covered directly by NAK or VOV. VOV2006 contains questions on senior employees' policies, which also include flexible planning of tasks and working hours. 
- What have you done to increase adherence of senior employees within the last 3 years) (11 response categories)

VOV2006-17:

\section{Finland}

Description:

- Does the work place use flexible job descriptions?

WHS : Q26B \& WCB: 2 questions

\section{Norway}

- To what extent are you free to decide your own tasks?

- To what extent are you free to decide how to go about doing your work?

- Are you free to choose when to take a break from your work; e.g. to stretch your legs or take a breather in some other way?

- To what extent can you influence decisions that are important to your work?

- To what extend can you decide the pace which your work?

\section{Sweden}

Description:

- Is it possible for you to decide on your own when various tasks are to be done (for example, by choosing to work a bit faster some days and taking it easier other days)?

WES 


\begin{tabular}{|c|c|c|c|c|c|}
\hline & DK & FI & NO & sW & Total \\
\hline Overall grade & & & & & C \\
\hline 1. Relevance & B & B & B & B & C \\
\hline 2. Accuracy & A & A & A & A & A \\
\hline $\begin{array}{l}\text { 2. Cross- } \\
\text { country } \\
\text { comparable }\end{array}$ & & & & & C \\
\hline $\begin{array}{l}\text { 3. Availability } \\
\text { across coun- } \\
\text { tries }\end{array}$ & & & & & B \\
\hline $\begin{array}{l}\text { 3. Availability } \\
\text { over time }\end{array}$ & C & B & A & B, WES & C \\
\hline $\begin{array}{l}\text { Linking } \\
\text { possibility }\end{array}$ & A & No & No & WES: A & C \\
\hline $\begin{array}{l}\text { Source and } \\
\text { ownership }\end{array}$ & $\begin{array}{l}\text { VOV, National } \\
\text { Research centre } \\
\text { for the Working } \\
\text { Environment }\end{array}$ & $\begin{array}{l}\text { WHS: Work \& Health } \\
\text { Survey, Finland, FIOH, } \\
\text { (Työ ja Terveys), evry } 3 \\
\text { years } \\
\text { WCB: Työolobarometri } \\
\text { (Working Condition } \\
\text { Barometer), Finland, } \\
\text { MOL, annual }\end{array}$ & $\begin{array}{l}\text { Norwegian } \\
\text { level of living } \\
\text { condition } \\
\text { survey - } \\
\text { working } \\
\text { environment, } \\
\text { SSB }\end{array}$ & $\begin{array}{l}\text { WES: The } \\
\text { Swedish Work } \\
\text { Environment } \\
\text { Survey. SCB and } \\
\text { Swedish Work } \\
\text { Environment } \\
\text { Authority }\end{array}$ & \\
\hline $\begin{array}{l}\text { Accessible } \\
\text { data? }\end{array}$ & Yes & Yes & No & Yes & B \\
\hline
\end{tabular}

Source: DAMVAD and expert group, 2011.

Swedish comment: Research job satisfaction is driven by higher involvement of workers through flexible work systems that provide better communication between workers and increased autonomy in performing the work (Bauer, 2004)

\subsubsection{Social Support From Management}

Social support from the management appears to be preventing decreasing absence. E.g. support from management gives a sense of job security and helps prevent negative behavior from co-workers.

\section{Denmark}

Description:

- Do you gain help and support from you superior? NAK2005-140; 3 og NAK 2010-24; 4

- Is your superior motivated for listening to your issues in relation to work?

NAK2005-140: 4 og NAK 2010-24; 3

- To what extent does the management at your workplace prioritize well-being highly?

NAK2005-137; 2: 
- Is there room for taking care of family and family issues at the workplace?

NAK2005-139:

- To what extent do your superior and the management provide opportunities to the employees generely speaking_(this question is unlikely to be perceived equally relevant in all job categories) NAK2010-26; 1

- The closest superior takes into consideration our needs and views, when he or she is making decisions.

NAK2010-28; 5:

\section{Finland}

Description:

ESWC: Q51, B and C

WCB - Only available in Finnish.

WHS - Only available in Finnish.

\section{Norway}

Description: Level of living conditions survey - working environment (LKU):

- How well do the following descriptions fit your immediate superior? Your immediate superior treats employees with trust and respect? Very well, Well, Not very well, Severely

- Do you get feedback from your superiors on how you have performed your work?

- Does your immediate superior treat employees fairly and impartially?

- Does your immediate superior value your achievements at work?

- At your workplace, if you state your opinions about working conditions, do you feel that you get listened to?

ESWC: Q51, B and C

\section{Sweden}

Description:

- Can you receive support and encouragement from your superiors when your work becomes troublesome? WES

- If your tasks feel difficult, do you have access to advice or help?

- WES

- If you think you have too much to do, is it possible for you to get in contact with your supervisor for setting of priorities?

WES 


\begin{tabular}{|c|c|c|c|c|c|}
\hline & DK & FI & No & sW & Total \\
\hline $\begin{array}{l}\text { Overall } \\
\text { grade }\end{array}$ & & & & & C \\
\hline 1. Relevance & A & B & A & B & B \\
\hline 2. Accuracy & A & A & A & A & A \\
\hline $\begin{array}{l}\text { 2. Cross- } \\
\text { country } \\
\text { comparable }\end{array}$ & & & & & B \\
\hline $\begin{array}{l}\text { 3. Availability } \\
\text { across } \\
\text { countries }\end{array}$ & & & & & B \\
\hline $\begin{array}{l}\text { 3. Availability } \\
\text { over time }\end{array}$ & C & $A-C$ & A & B, WES & C \\
\hline $\begin{array}{l}\text { Linking } \\
\text { possibility }\end{array}$ & A & No & No & WES: A & $C$ \\
\hline $\begin{array}{l}\text { Source and } \\
\text { ownership }\end{array}$ & $\begin{array}{l}\text { NAK, National } \\
\text { Research centre } \\
\text { for the Working } \\
\text { Environment } \\
\text { VOV, National } \\
\text { Research centre } \\
\text { for the Working } \\
\text { Environment }\end{array}$ & $\begin{array}{l}\text { WCB: Työolobarometri } \\
\text { (Working Condition } \\
\text { Barometer), Finland, } \\
\text { MOL, annual } \\
\text { WHS: Work \& Health } \\
\text { Survey, Finland, FIOH, } \\
\text { (Työ ja Terveys), evry } 3 \\
\text { years } \\
\text { EWCS: European } \\
\text { Working Conditions } \\
\text { Survey }\end{array}$ & $\begin{array}{l}\text { Norwegian } \\
\text { level of living } \\
\text { condition } \\
\text { survey - } \\
\text { working envi- } \\
\text { ronment, SSB }\end{array}$ & $\begin{array}{l}\text { WES: The } \\
\text { Swedish Work } \\
\text { Environment } \\
\text { Survey. SCB and } \\
\text { Swedish Work } \\
\text { Environment } \\
\text { Authority }\end{array}$ & \\
\hline $\begin{array}{l}\text { Accessible } \\
\text { data? }\end{array}$ & Yes & Yes & No & Yes & B \\
\hline
\end{tabular}

Source: DAMVAD and expert group, 2011.

\subsubsection{Problem Solving, Dialogue Oriented Collaboration Climate}

A climate of collaboration is seen as having a positive impact across the countries. This goes for vertical as well as horizontal collaboration. At the core of this is dialogue and a question-and-answer-oriented interaction as well as the culture of challenging ideas in a constructive manner. Establishing a well-functioning team climate is therefore important in many ways.

\section{Denmark}

Description: VOV does not contain questions which directly include collaboration climate, but VOV and NAK contain a range of questions indirectly covering aspects of the subject.

- I am fully aware of my areas of responsibility? NAK2005-143; 1 :

- Contradicting demands are being put into me at my work? NAK2005-143; 2: 
- Do you receive important information, e.g. about central decisions, changes and future plans in proper time?

NAK2005-136; 10 and NAK2010-25; 6:

- Do you receive all relevant information in order to do a satisfactory job?

NAK2005-136; 11 and NAK2010-25;7:

- We always seek out and help each other to obtain the best possible result at work?

NAK2010-28; 7:

- We always approach each other and collaborate to find solutions to problems.

NAK2010-28; 8:

- How many meetings have been held last year where both representative from employees and management attended, e.g. in the organization of security, collaboration board or in other informal forums? VOV2006-11:

- Do you discuss work well-being issues in meetings where both employees and management are present?

VOV2006-12:

\section{Finland}

Description:

WHS: QJ24

\section{Norway}

Description:

Level of living conditions survey - working environment:

- Does the workplace promote a climate of collaboration and constructive dialogue?

- If you express your point of view concerning the working conditions at your work place, are they taken into account?

- Do you risk being met with reluctance from your superiors if you make critical comments about the working conditions at your workplace?

\section{Sweden}

Description:

- Do you spend part of your workday comprehending or solving complex problems?

WES

- Do you hesitate to present criticism of your working conditions? WES 


\begin{tabular}{|c|c|c|c|c|c|}
\hline & DK & $\mathbf{F I}$ & NO & sw & Total \\
\hline Overall grade & & & & & C \\
\hline 1. Relevance & A & B & B & B & C \\
\hline 2. Accuracy & A & A & A & A & A \\
\hline $\begin{array}{l}\text { 2. Cross-country } \\
\text { comparable }\end{array}$ & & & & & B \\
\hline $\begin{array}{l}\text { 3. Availability } \\
\text { across countries }\end{array}$ & & & & & A \\
\hline $\begin{array}{l}\text { 3. Availability } \\
\text { over time }\end{array}$ & C & B & B & B, WES & C \\
\hline $\begin{array}{l}\text { Linking } \\
\text { possibility }\end{array}$ & A & No & No & WES: A & C \\
\hline $\begin{array}{l}\text { Source and } \\
\text { ownership }\end{array}$ & $\begin{array}{l}\text { NAK, National } \\
\text { Research centre } \\
\text { for the Working } \\
\text { Environment } \\
\text { VOV, National } \\
\text { Research centre } \\
\text { for the Working } \\
\text { Environment }\end{array}$ & $\begin{array}{l}\text { WHS: Work \& } \\
\text { Health Survey, } \\
\text { Finland, FIOH, } \\
\text { (Työ ja Terveys), } \\
\text { evry } 3 \text { years }\end{array}$ & $\begin{array}{l}\text { Norwegian level } \\
\text { of living condi- } \\
\text { tion survey- } \\
\text { working envi- } \\
\text { ronment, SSB }\end{array}$ & $\begin{array}{l}\text { WES: The Swedish } \\
\text { Work Environment } \\
\text { Survey. SCB and } \\
\text { Swedish Work } \\
\text { Environment } \\
\text { Authority }\end{array}$ & \\
\hline Accessible data? & Yes & Yes & Yes & Yes & A \\
\hline
\end{tabular}

Source: DAMVAD and expert group, 2011.

\subsubsection{Social Support from Colleagues}

Social support from colleagues is in many studies viewed as an important aspect of the work well-being. Social support makes the employee feel included in the community, helps if the employees have either professional or private difficulties and gives a feeling of security for the employee.

\section{Denmark}

Description: VOV does not contain the questions about social support.

- How often do you receive help and support from your colleagues? NAK2005-140;1 and NAK2010-24;2:

- How often are your colleagues willing to listen to your problems at work?

NAK2005-140-2 and NAK2010-24;1:

- We always seek out and help each other to obtain the best possible result at work?

NAK2010-28; 7:

- We always approach each other and collaborate to find solutions to problems.

NAK2010-28; 8:

- Do you and your colleagues recognize each other among yourselves NAK2010-24; 9: 


\section{Finland}

Description:

- ESWC: Q51, A

WCB - Only available in Finnish.

- WHS - Only available in Finnish.

\section{Norway}

Description: There are no available data on company level. We have a single item measuring social support in the work setting.

Level of living conditions survey - working environment:

- Which level of social support among colleagues is present in the company?

- If you need it, how often can you get the support and help of your colleagues with your work?

\section{Sweden}

Description:

- Do you receive support and encouragement from your fellow workers when your work becomes troublesome?

WES

- Do other persons express appreciation for your work (e.g. fellow workers, patients, customers, clients, passengers, students)? WES 


\begin{tabular}{|c|c|c|c|c|c|}
\hline & DK & FI & NO & sw & Total \\
\hline Overall grade & & & & & C \\
\hline 1. Relevance & A & B & B & B & C \\
\hline 2. Accuracy & A & A & A & A & A \\
\hline $\begin{array}{l}\text { 2. Cross- } \\
\text { country } \\
\text { comparable }\end{array}$ & & & & & A \\
\hline $\begin{array}{l}\text { 3. Availability } \\
\text { across } \\
\text { countries }\end{array}$ & & & & & A \\
\hline $\begin{array}{l}\text { 3. Availability } \\
\text { over time }\end{array}$ & C & $A-C$ & B & B, WES & C \\
\hline $\begin{array}{l}\text { Linking possi- } \\
\text { bility }\end{array}$ & Yes & No & No & WES: A & C \\
\hline $\begin{array}{l}\text { Source and } \\
\text { ownership }\end{array}$ & $\begin{array}{l}\text { NAK, National } \\
\text { Research } \\
\text { centre for the } \\
\text { Working } \\
\text { Environment }\end{array}$ & $\begin{array}{l}\text { EWCS: European Working } \\
\text { Conditions Survey } \\
\text { WHS: Work \& Health Survey, } \\
\text { Finland, FIOH, (Työ ja Ter- } \\
\text { veys), evry } 3 \text { years } \\
\text { WCB: Työolobarometri } \\
\text { (Working Condition Barome- } \\
\text { ter), Finland, MOL, annual }\end{array}$ & $\begin{array}{l}\text { Norwegian } \\
\text { level of living } \\
\text { condition } \\
\text { survey - } \\
\text { working } \\
\text { environment, } \\
\text { SSB }\end{array}$ & $\begin{array}{l}\text { WES: The } \\
\text { Swedish Work } \\
\text { Environment } \\
\text { Survey. SCB and } \\
\text { Swedish Work } \\
\text { Environment } \\
\text { Authority }\end{array}$ & \\
\hline $\begin{array}{l}\text { Accessible } \\
\text { data? }\end{array}$ & Yes & Yes & Yes & Yes & A \\
\hline
\end{tabular}

Source: DAMVAD and expert group, 2011.

\subsubsection{Clarity of Roles}

The distribution of various tasks amongst employees and the level of responsibility are important for the employees to experience a certain amount of security and predictability among the working tasks. Uncertainty regarding who has the final word implies a potential conflict and thereby a bad work well-being.

\section{Denmark}

Description: VOV does not contain questions on clarity of roles.

- I am fully aware of my areas of responsibility NAK2005-143; 1 :

- Contradicting demands are been put forward to me at work NAK2005-143; 2:

\section{Finland}

Description:

WHS: QJ24b

EWCS: Q51K 


\section{Norway}

Description:

Level of living conditions survey - working environment:

- Is it obvious who has the responsibility for different tasks and who has different roles?

- How often is it unclear what is expected of you in your job?

\section{Sweden}

Description:

- I am familiar with the overall company goals

- I have clearly defined goals

- My individual goals are followed up

- In my work group our goals are regularly followed up

- I understand what our valuess mean in my everyday work ECQ

\begin{tabular}{|c|c|c|c|c|c|}
\hline & DK & FI & No & sw & Tota \\
\hline Overall grade & & & & & c \\
\hline 1. Relevance & B & B & B & B & c \\
\hline 2. Accuracy & A & A & A & A & A \\
\hline $\begin{array}{l}\text { 2. Cross- } \\
\text { country } \\
\text { comparable }\end{array}$ & & & & & c \\
\hline $\begin{array}{l}\text { 3. Availability } \\
\text { across } \\
\text { countries }\end{array}$ & & & & & B \\
\hline $\begin{array}{l}\text { 3. Availability } \\
\text { over time }\end{array}$ & c & B & A & $B, W E S$ & c \\
\hline $\begin{array}{l}\text { Linking } \\
\text { possibility }\end{array}$ & A & No & No & WES: A & c \\
\hline $\begin{array}{l}\text { Source and } \\
\text { ownership }\end{array}$ & $\begin{array}{l}\text { VOV, National } \\
\text { Research centre } \\
\text { for the Working } \\
\text { Environment }\end{array}$ & $\begin{array}{l}\text { WHS: Work \& Health } \\
\text { Survey, Finland, FIOH, } \\
\text { (Työ ja Terveys), evry } \\
3 \text { years } \\
\text { WCB: Työolobaro- } \\
\text { metri (Working } \\
\text { Condition Barometer), } \\
\text { Finland, MOL, annual }\end{array}$ & $\begin{array}{l}\text { Norwegian level } \\
\text { of living condi- } \\
\text { tion survey- } \\
\text { working envi- } \\
\text { ronment, SSB }\end{array}$ & $\begin{array}{l}\text { WES: The Swe- } \\
\text { dish Work } \\
\text { Environment } \\
\text { Survey. SCB and } \\
\text { Swedish Work } \\
\text { Environment } \\
\text { Authority }\end{array}$ & \\
\hline $\begin{array}{l}\text { Accessible } \\
\text { data? }\end{array}$ & Yes & Yes & No & Yes & B \\
\hline
\end{tabular}

Source: DAMVAD and expert group, 2011.

DAMVAD comment regarding Swedish data: If the ECQ questionnaire is not linkable to companies, we propose to skip the data. It will not be useable for productivity analysis. 


\subsubsection{Work Scheduling}

WE can to a large degree be defined by the way the work is scheduled and the amount of work expected by the employer. This is a subject that includes many sub-themes. One theme is how the work is scheduled with regards to working hours, daytime/nighttime and the opportunities to get reasonable rest. Does the employer expect that the employees work many hours each day, it can be stressing and even though it can improve the production volume in the short run, it can also undermine the effort in the longer run as long as employees are stressed, run-down etc. Furthermore, if the work is scheduled to hours making it difficult for the employees to have a well-functioning work/life balance, it can in the longer run cause absenteeism, high employee turnover etc.

Another aspect is whether the working hours are changing or more or less fixed. Changing working hours, e.g. as part of shift work, imposes a stress to the human organism in terms of difficulties regarding having a circadian and biological rhythm.

\section{Denmark}

Description: VOV does not contain questions on the planning of working hours.

- How is your time at work normally planned? NAK2005-100:

- At what time a day do you normally work? NAK2010-6:

- Do you actively plan your work and work load? NAK2010-20:

- Is your job varied? NAK2010-21:

- Does your job require a lot of repetition and repeats several times an hour? NAK2010-22:

- How often is your work unevenly distributed so that it accumulates? NAK2010-23; 1 :

- How often do you not complete all of your tasks? NAK2010-23; 2:

- How often is it necessary to do overtime? NAK2010-23; 3:

\section{Finland}

Description:

- Is the work organized and scheduled in an appropriate way? WHS: B26 


\section{Norway}

Description:

There is no data on whether the work is organized and scheduled in an appropriate way. However, there is available data on working hours and shift work, including night work:

- What are your agreed weekly working hours in your main job?[1-31 hours, 32-36 hours]

- How many hours do you normally work in total per week in your main job? Include paid overtime and extra work done at home related to this job.

- Is this a full-time or part-time job?

- You have said that you normally work longer than your agreed working hours. Is any of the overtime that you do paid, or are you able to take time off in lieu?[Yes/no ]

- What are your normal working hours? [Daytime between 6 am and 6 pm, Shift or rota work, Other arrangement]

- Can you estimate how many nights you worked? (last 12 months)

- How many nights in a row have you worked over the past 12 weeks?

\section{Sweden}

Description:

- Is there any part of your work day when you do nothing but wait and remain prepared in case something might happen? WES

- In the mains can you take short breaks at any time in order to talk? WES

- Does your work occasionally require you to perform nothing but repetitive tasks several times per hour?

WES 


\begin{tabular}{|c|c|c|c|c|c|}
\hline & DK & FI & NO & SW & Total \\
\hline Overall grade & & & & & C \\
\hline 1. Relevance & A & B & B & B & C \\
\hline 2. Accuracy & A & A & A & A & A \\
\hline $\begin{array}{l}\text { 2. Cross-country } \\
\text { comparable }\end{array}$ & & & & & B \\
\hline $\begin{array}{l}\text { 3. Availability } \\
\text { across countries }\end{array}$ & & & & & A \\
\hline $\begin{array}{l}\text { 3. Availability } \\
\text { over time }\end{array}$ & C & B & B & B, WES & C \\
\hline $\begin{array}{l}\text { Linking } \\
\text { possibility }\end{array}$ & A & No & No & WES: A & C \\
\hline $\begin{array}{l}\text { Source and } \\
\text { ownership }\end{array}$ & $\begin{array}{l}\text { NAK, National } \\
\text { Research centre } \\
\text { for the Working } \\
\text { Environment }\end{array}$ & $\begin{array}{l}\text { WHS: Work \& } \\
\text { Health } \\
\text { Survey, } \\
\text { Finland, FIOH, } \\
\text { (Työ ja } \\
\text { Terveys), evry } \\
3 \text { years }\end{array}$ & $\begin{array}{l}\text { Norwegian level of } \\
\text { living condition } \\
\text { survey - working } \\
\text { environment, SSB } \\
\text { The labour force } \\
\text { survey, SSB }\end{array}$ & $\begin{array}{l}\text { WES: The Swedish } \\
\text { Work Environment } \\
\text { Survey. SCB and } \\
\text { Swedish Work } \\
\text { Environment } \\
\text { Authority }\end{array}$ & \\
\hline Accessible data? & Yes & Yes & Yes & Yes & A \\
\hline
\end{tabular}

Source: DAMVAD and expert group, 2011.

Norway: Description of relevance, is it a direct measure or indirect measure of the indicator?

DAMVAD comment to Norwegian data: This is an indirect measurement stating something about the ability to control the work situation.

\subsubsection{Working Communities / Group Work}

Working communities imply that the individual employee is not necessarily responsible for the total delivery in the project. Furthermore, organizing in working communities also ensures social support from colleagues as well as distributing workloads among several employees.

\section{Denmark}

Description: Is not covered by neither NAK nor VOV.

\section{Finland}

EWCS: Q56

WHS:

\section{Norway}

No data 


\section{Sweden}

Description:

- How do you experience your work? Too little support and help from fellow workers and superiors?

WES

- How do you experience your work? Too isolated from others? WES

\begin{tabular}{|c|c|c|c|c|c|}
\hline & DK & FI & NO & SW & Total \\
\hline Overall grade & & & & & C \\
\hline 1. Relevance & N/A & B & $\mathrm{N} / \mathrm{A}$ & B & C \\
\hline 2. Accuracy & N/A & A & N/A & A & C \\
\hline $\begin{array}{l}\text { 2. Cross-country compa- } \\
\text { rable }\end{array}$ & & & & & C \\
\hline $\begin{array}{l}\text { 3. Availability across } \\
\text { countries }\end{array}$ & & & & & C \\
\hline 3. Availability over time & N/A & $B, C$ & N/A & B, WES & C \\
\hline Linking possibility & N/A & No & $\mathrm{N} / \mathrm{A}$ & WES: A & C \\
\hline Source and ownership & & $\begin{array}{l}\text { EWCS: Europe- } \\
\text { an Working } \\
\text { Conditions } \\
\text { Survey } \\
\text { WHS: Work \& } \\
\text { Health Survey, } \\
\text { Finland, FIOH, } \\
\text { (Työ ja Ter- } \\
\text { veys), evry } 3 \\
\text { years }\end{array}$ & & $\begin{array}{l}\text { WES: The Swedish } \\
\text { Work Environment } \\
\text { Survey. SCB and } \\
\text { Swedish Work } \\
\text { Environment } \\
\text { Authority }\end{array}$ & \\
\hline Accessible data? & No & Yes & No & Yes & c \\
\hline
\end{tabular}

Source: DAMVAD and expert group, 2011.

\subsubsection{Norway - General Comment on the Following Indicators.}

There are no specific national data addressing the following indicators. In the level of living conditions there are some general questions addressing OSH-resources at company level.

- Does your company have a safety representative, i.e. someone who raises issues relating to the working environment on behalf of employees?[YES/NO]

- Does your company have a working environment committee or other committees that deal with issues relating to the working environment?[YES/NO]

- Does your employer have a company health service? [Yes/no] 
- Have you had any contact with anyone who works at the company health service over the past 12 months?

EU-OSHA's European survey of enterprises on new and emerging risks (ESENER) could provide more detailed data on how health and safety risks are managed at their workplace. The ESENER survey explores the views of managers and workers' representatives. LINK: http://osha. europa.eu/sub/esener/en

ESENER are also providing data for all the four Nordic countries on the exact same questions.

\subsubsection{Sweden - General Comment on the Following Indicators.}

In Sweden there is a legal obligation on systematic work environment management. Amongst other things it involves that the employer regularly investigates work conditions and assesses risks for illness and accidents at work and that the employer implements actions required for prevention of poor health conditions and accidents as soon as possible.

In addition there is a legal obligation to have a work environment committee.

\subsubsection{Evaluation Tools}

In order for a company to work strategically with work well-being it can be necessary to assess the actual work well-being in the company. Using tools in order to assess oneself, enable companies to find out where improvement is needed. Furthermore, it can form the basis of a dialogue and a process for improving the work well-being.

- Does the company evaluate the work well-being?

\section{Denmark}

Description: The statutory tool is APV (arbejdspladsvurdering=work place assessment), which should be undertaken for the physical as well as the psychological working environment. The organizing of the company's efforts for improvement of the working environment is defined in regulations on the safety and collaboration organization. Health promotion in the work place is not statutory, yet is offered by many companies:

- Within the past three years, has there been a work place assessment (APV/WPA) in your current work place?

NAK2005-104

- Do you have a safety organization/safety representative in your work place?

NAK2005-103 
- Within the past year, have you been offered health promotion via your work place? - and have you made use of the offer? (6 response categories=types of health promotion)

NAK2010-9

- Have you made a formal work place assessment, also known as $\mathrm{APV} / \mathrm{WPA}$, in your work place? VOV2006-4

- When is the last time you have done an AOV at your work place? VOV2006-5

- Was the last APV/WPA that you did written? VOV2006-6

- Within the past three years, have you been going through the working environment in your work place, e.g. when doing an APV/WPA, focusing on [industrial injuries], [psychological working environment], [ergonomic problems], [indoor climate], [noise], [chemicals, gasses, smoke, dust or wet work]? VOV2006-7

- Within the past three years, e.g. when doing an APV/WPA, have you noticed any problems with the working environment at the work place? VOV2006-8

- Has the character, seriousness and extend of these problems been assessed? VOV2006-9

- Has a written plan of action for how to solve the problems been made? VOV2006-10

\section{Finland}

SWBS: questions about work climate survey and HR-reporting WHS: QL12-1 (HR-reporting)

\section{Norway}

\section{ESENER, Management}

- What health and safety services do you use, be it in-house or contracted externally?

- Does your establishment routinely analyse the cause of sickness absence?

- Do you take measures to support employees' return to work following a long term sickness absence?

- Is the health of employees monitored through regular medical examinations? 


\section{Sweden}

- Are systematic work environment activities currently ongoing at your work place?

WES

- Are deficiencies in the work environment taken care of within reasonable time?

WES

- Has there been a survey of the work environment with an assessment of the risks for poor health and accidents found at your workplace? QWE

- Have the results of this work been documented in writing? QWE

- Have those risks noted in the survey of the work environment been taken care of? QWE

- If one or more risks were not taken care of directly, is there a plan that describes when these risks would be taken care of, naming the person who is responsible for handling the matter? QWE

- Does your employer provide occupational health services? $\mathrm{QOH}$

- Has anyone from occupational health services been at your workplace during the last 12 months? For example, to assess possible risks at the workplace and suggest solutions if necessary? $\mathrm{QOH}$

- Have occupational health services made an assessment of your work situation in any other ways? For example, in connection with your visit to occupational health services or by telephone? $\mathrm{QOH}$

- Which of the following areas were involved? $\mathrm{QOH}$

a) Working postures, work movements, or heavy work

b) Heavy workload or stress

c) Cooperation or relations at the workplace

d) Adjustment of working duties or rehabilitation

e) Technical equipment, i.e. machines, lighting, noise

f) Sickness absence

g) Problems with substance misuse, i. e. alcohol, narcotics

h) Organization of work 


\begin{tabular}{|c|c|c|c|c|c|}
\hline & DK & $\mathbf{F I}$ & No & sw & Total \\
\hline Overall grade & & & & & C \\
\hline 1. Relevance & A & B & B & B & C \\
\hline 2. Accuracy & A & A & A & A & $A$ \\
\hline 2. Cross-country comparable & & & & & B \\
\hline 3. Availability across countries & & & & & B \\
\hline 3. Availability over time & B & $\begin{array}{l}\text { SWBS: A } \\
\text { WHS: B }\end{array}$ & A & B & B \\
\hline Linking possibility & A & C & NO & Yes & C \\
\hline Source and ownership & $\begin{array}{l}\text { NAK } \\
\text { VOV } \\
\text { Both NFA }\end{array}$ & $\begin{array}{l}\text { SWBS } \\
\text { WHS }\end{array}$ & LKU & $\begin{array}{l}\text { WES } \\
\text { QWE } \\
\text { QOH }\end{array}$ & \\
\hline Accessible data? & A & & & & - \\
\hline
\end{tabular}

Source: DAMVAD and expert group, 2011.

\subsubsection{Personnel Policy}

Personnel policy can be a strategic framework for defining work wellbeing practice in the company in order to make sure that there is a common way to work with working environment.

- Does the company have a personnel policy regarding work wellbeing?

\section{Denmark}

Description: VOV contains questions on senior employees' policies (VOV2006-16 and VOV2006-17). The subject is only covered indirectly and sporadically in NAK.

- Does your working place create space for employees with different disabilities and handicaps?

NAK2005-138:

Does your working place give you an option for taking care of your family when needed?

NAK2005-139

\section{Finland}

SWBS

\section{Norway}

No data 


\section{Sweden}

RESEARCH Quality of personnel policy relates to productivity and profitability in firms (Ulrich, 1997; Tamkin et al, 2004; Pfau \& kay, 2002)

\begin{tabular}{|c|c|c|c|c|c|}
\hline & DK & FI & NO & SE & Total \\
\hline Overall grade & & & & & C \\
\hline 1. Relevance & B & B & - & - & C \\
\hline 2. Accuracy & A & A & - & - & B \\
\hline 2. Cross-country comparable & & & & & - \\
\hline 3. Availability across countries & & & & & c \\
\hline 3. Availability over time & $\mathrm{C}$ & A & - & - & c \\
\hline Linking possibility & Yes & No & - & - & c \\
\hline Source and ownership & NAK, NFA & SWBS & - & - & \\
\hline Accessible data? & A & & & & C \\
\hline
\end{tabular}

Source: DAMVAD and expert group, 2011.

\subsubsection{Work Well-Being Programs and Plans}

A strategic way to promote better work well-being is by using a work well-being plan or by establishing a program to promote work wellbeing. Having identified focus areas or crucial challenges to address either beforehand or as a reaction of an identified problem implies that there is a possibility to address the issues.

- Does the company have a work environment program or work wellbeing plan in order to promote work well-being? Work well-being plans could relate to different issues such as:

- Bullying

- Physically hard work

- Work accidents

- Chemicals and other dangerous materials

- Sedentary work

\section{Denmark}

Description: VOV has a range of questions regarding actions and plans which on a company level aim at preventing problems with the working environment related to:

- Industrial injuries VOV2006-18, VOV2006-19, VOV2006-21, VOV2006-23, VOV2006-24, VOV2006-26, VOV2006-28, VOV2006-30

- Psychological working environment VOV2006-37, VOV2006-40, VOV2006-41, VOV2006-42, VOV2006-44, VOV2006-45

- Physically straining work VOV2006-47, VOV2006-49, VOV2006-51, VOV2006-52, VOV2006-54 (fysisk krævende arbejde), VOV2006-56 (sedentary work)

- Indoor climate VOV2006-59, VOV2006-60, VOV2006-62

- Noise VOV2006-64, VOV2006-66, VOV2006-68, VOV2006-70, VOV2006-74, VOV2006-76 
- Chemicals VOV2006-79

NAK does not have questions which elucidate whether the company has programs/plans with the purpose of preventing negative effects of different working environment influences. By contrast, NAK has questions on the employees' experiences of being under the different working environment influences - typically as a share of the working time.

\section{Finland}

SWBS

\section{Norway}

No data

\section{Sweden}

RESEARCH High levels of stress, excessive body weight, and multiple risk factors (individuals scoring high on several sickness-related factors) are associated with increased healthcare costs and illness-related absenteeism (Aldana, 2001)

\begin{tabular}{llllll}
\multicolumn{1}{l}{ Work Well-Being Programs and Plans } & & & \\
\hline & DK & FI & NO & SW & Total \\
\hline Overall grade & & & & C \\
1. Relevance & A & B & - & - & C \\
2. Accuracy & A & A & - & - & B \\
2. Cross-country comparable & & & & \\
3. Availability across countries & & A & - & - & C \\
3. Availability over time & C & No & - & - & \\
Linking possibility & Yes & - & - & \\
Source and ownership & VOV, NFA & SWBS & - & & \\
Accessible data? & A & & & & \\
\hline
\end{tabular}

Source: DAMVAD and expert group, 2011.

\subsubsection{Work Well-Being or Safety Organisation}

A specific organizational unit handling work well-being questions is seen as a way to professionalize work well-being issues. It ensures that work wellbeing is on the agenda from time to time and it ensures that there is a forum in which to handle issues regarding work well-being on a regular basis.

- Does the work place have an organizational unit which handles work well-being issues? 


\section{Denmark}

- How is the working environment organized? VOV2006-3

- Does a safety organization or safety representative exist in your work place?

NAK2005-103

\section{Finland}

SWBS

\section{Norway}

LKU

- Does your company have a working environment committee or other committees that deal with issues relating to the working environment?

\section{Sweden}

- As safety delegate, do you participate in the systematic work environment work at your workplace?

QWES

The question was originally used to measure employee attitudes but the content of the question could nevertheless be used as indicator for company practise. The latter indicator may not provide an extensive definition of the above overall indicator but it could serve as proxy and be combined with other aspects.

\begin{tabular}{|c|c|c|c|c|c|}
\hline & DK & FI & NO & sw & Total \\
\hline Overall grade & & & & & C \\
\hline 1. Relevance & A & B & B & B & C \\
\hline 2. Accuracy & A & A & A & A & A \\
\hline 2. Cross-country comparable & & & & & B \\
\hline $\begin{array}{l}\text { 3. Availability across } \\
\text { countries }\end{array}$ & & & & & B \\
\hline 3. Availability over time & C & A & $-A$ & B & B \\
\hline Linking possibility & Yes & No & $-\mathrm{NO}$ & Yes & C \\
\hline Source and ownership & $\begin{array}{l}\text { NAK } \\
\text { VOV, } \\
\text { Both NFA }\end{array}$ & SWBS & $\begin{array}{l}\text { - Norwegian level of } \\
\text { living condition survey - } \\
\text { working environment, } \\
\text { SSB }\end{array}$ & QWES & \\
\hline Accessible data? & A & & & & \\
\hline
\end{tabular}

Source: DAMVAD and expert group, 2011. 


\subsubsection{Certification in Work Well-Being}

A certification can help systematizing the work with work well-being as well as documenting the effects. Furthermore certification often implies that companies must spend more resources in their work environment effort as well as it helps the company prove that the company works seriously with work well-being.

- Is the company certified in handling the work well-being (in one way or another)?

\section{Denmark}

Description: NAK and VOV do not contain questions on cerfification in work well being. Certified companies are registered at AT's (The Danish Working Environment Authority) homepage.

\section{Finland}

SWBS

\section{Norway}

No data available.

\section{Sweden}

Legal obligation of employers to measure.

\begin{tabular}{llllll}
\multicolumn{1}{l}{ Certification in Work Well-Being } & & & & \\
\hline & DK & FI & NO & SW & Total \\
\hline Overall grade & & & & - \\
1. Relevance & - & B & - & - \\
2. Accuracy & - & A & - & \\
2. Cross-country comparable & & & & - \\
3. Availability across countries & & A & - & - \\
3. Availability over time & - & No & - & - \\
Linking possibility & - & SWBS & - & \\
Source and ownership & - & & & \\
Accessible data? & & &
\end{tabular}

Source: DAMVAD and expert group, 2011.

\subsubsection{General Training and Competence Development}

An important factor for employees is whether they have opportunities to develop their skills within their job. Education and training gives the employees better possibilities to keep their job, perform better and thus improve economic outputs in the company.

- Does the company provide training and education for their employees? 


\section{Denmark}

Description: VOV does not contain questions, which directly answer whether the companies have policies regarding general job training and competence development.

However, they can be answered indirectly by:

- What have you done to increase the employees' development possibilities within the past three years?

VOV2006-40

- Within the past 12 months whilst working at your current work place, have you participated in courses or supplementary training (6 response categories with increasing duration)

NAK2005-105

- To which extend have you had the possibility to learn something new through your work place?

NAK2010-25; 2

\section{Finland}

SWBS

WCB

\section{Norway}

LKU

- In your job, how good are your opportunities to develop your skills in the areas that interests you?

- In your job, how good are your opportunitites to make use of the skills, knowledge, and experience that you have gained through your education and past work.

- How often does your job require you to acquire new knowledge and skills?

\section{Sweden}

No data 


\begin{tabular}{|c|c|c|c|c|c|}
\hline & DK & FI & NO & SW & Total \\
\hline Overall grade & & & & & C \\
\hline 1. Relevance & A & B & A & - & C \\
\hline 2. Accuracy & A & A & A & - & B \\
\hline \multicolumn{6}{|l|}{ 2. Cross-country comparable } \\
\hline 3. Availability across countries & & & & & c \\
\hline 3. Availability over time & C & A & A & - & c \\
\hline Linking possibility & Yes & No & NO & - & C \\
\hline Source and ownership & $\begin{array}{l}\text { VOV, NAK, } \\
\text { both NFA }\end{array}$ & $\begin{array}{l}\text { SWBS } \\
\text { WCB }\end{array}$ & $\begin{array}{l}\text { Norwegian level of living } \\
\text { condition survey - working } \\
\text { environment, SSB }\end{array}$ & - & \\
\hline Accessible data? & A & & & & \\
\hline
\end{tabular}

Source: DAMVAD and expert group, 2011.

\subsubsection{Regular Evaluation of Training Needs and Wishes}

In order to find out if employees have the appropriate skills and therefore are able to perform their job with satisfaction and have a future in the organization, the company can make a more regular evaluation of the needs. It gives the opportunity to ensure that employees are and feel valuable for the work place.

- Does the company in a systemized manner evaluate the need for training for individual employees?

\section{Denmark}

Description: Is not covered in VOV and NAK

\section{Finland}

SWBS

\section{Norway}

No data available.

\section{Sweden}

No data 
Regular evaluation of training needs and wishes

\begin{tabular}{llllll} 
& DK & FI & NO & SW & Total \\
\hline Overall grade & & & & \\
1. Relevance & - & B & - & - \\
2. Accuracy & - & A & - & - \\
2. Cross-country comparable & & & & \\
3. Availability across countries & & A & - & - \\
3. Availability over time & - & No & - & - \\
Linking possibility & - & SWBS & - & -
\end{tabular}

Source: DAMVAD and expert group, 2011.

\subsubsection{Training in Work Well-Being}

The purpose with work well-being training is to strengthen the work well-being efforts in companies.

- Does the company or any of the employees in the company participate in training activities aimed at improving their work wellbeing skills?

\section{Denmark}

Description: Is not covered in VOV and NAK

\section{Finland}

SWBS

\section{Norway}

No data available.

\section{Sweden}

No data

Training in work well-being

\begin{tabular}{llllll}
\hline & DK & FI & NO & sW & Total \\
\hline Overall grade & & & & \\
1. Relevance & - & B & - & - \\
2. Accuracy & - & A & - & - \\
2. Cross-country comparable & & & & \\
3. Availability across countries & - & A & - & - \\
3. Availability over time & - & No & - & - \\
Linking possibility & - & SWBS & - & - \\
Source and ownership & - & & & - \\
Accessible data? & & & & \\
\hline
\end{tabular}

Source: DAMVAD and expert group, 2011. 


\subsubsection{Countering Repetitive Work and Hard Physical Work}

It is relevant to consider how companies work to reduce the repetitive work as well as hard physical work, (Arbejdstilsynet 2010), (Alexanderson $\mathrm{K}$ et.a. 2004), because it is expected to correlate with sickness and physical attrition of the employees in the longer run.

- Does the work place have actions to lower the degree of repetitive work and hard physical work as much as possible?

\section{Denmark}

Physically straining work VOV2006-47,VOV2006-49, VOV2006-51, VOV2006-52, VOV2006-54 (physically demanding work), VOV2006-56 (sedentary work)

NAK does not have questions, which elucidate whether the company is actively seeking to reduce repetitive work and physically heavy work to the furthest possible extend. However, NAK has questions on the employees' experiences of being exposed to repetitive and physically hard work - typically as a share of the working time.

\section{Finland}

No data

\section{Norway}

No data available.

\section{Sweden}

Legal obligation of employers to measure.

\begin{tabular}{|c|c|c|c|c|c|}
\hline & DK & FI & NO & sW & Total \\
\hline \multicolumn{6}{|l|}{ Overall grade } \\
\hline 1. Relevance & A & - & - & - & \\
\hline 2. Accuracy & $A$ & - & - & - & \\
\hline \multicolumn{6}{|c|}{ 2. Cross-country comparable } \\
\hline \multicolumn{6}{|c|}{ 3. Availability across countries } \\
\hline 3. Availability over time & $\mathrm{C}$ & - & - & - & \\
\hline Linking possibility & Yes & - & - & - & \\
\hline Source and ownership & VOV, NFA & - & - & - & \\
\hline Accessible data? & A & & & - & \\
\hline
\end{tabular}

Source: DAMVAD and expert group, 2011.

\subsubsection{Ergonomics and Design}

The physical aspect of a working environment is important also in workplaces that are not affected by hard physical labor or other physical risks. Some workplaces work deliberately to improve the ergonomic conditions for their employees - some as a preventive measure and others as a reaction to complaints. 
- Does the company work to improve the ergonomic conditions in performing work tasks and/or to develop products with an ergonomic design in order to strengthen work well-being?

\section{Denmark}

Description: Is not covered by NAK. Partially covered by VOV as ergonomic initiatives and design are part of the response categories as well as the questions on physically straining work VOV2006-47,VOV2006-49, VOV2006-51, VOV2006-52, VOV2006-54 (physically demanding work), VOV2006-56 (sedentary work)

\section{Finland}

No data

\section{Norway}

No data

\section{Sweden}

Legal obligation of employers to measure.

\begin{tabular}{llllll} 
Ergonomics and Design & & & & & \\
\hline & DK & FI & NO & Total \\
\hline Overall grade & & & & \\
1. Relevance & A & - & - & - \\
2. Accuracy & B & - & - & \\
2. Cross-country comparable & & & & - \\
3. Availability across countries & & - & - & - \\
3. Availability over time & C & - & - & - \\
Linking possibility & Yes & - & - & \\
Source and ownership & VOV, NFA & - & & \\
Accessible data? & A & & &
\end{tabular}

Source: DAMVAD and expert group, 2011.

\subsubsection{Specific Action Plans and Action Concerning Noise, Chemicals, Indoor Climate etc.}

To avoid problems related to physical issues affecting the health and well-being of the employees, companies can take measures to avoid causing physical risks at their employees. This could be by introducing security equipment, training of employees, maintenance and investments in physical facilities etc.

- Does the company have specific measures concerning improvement of the physical surroundings and work well-being? E.g.:

- Noise

- Chemicals

- Indoor climate

- Others? 


\section{Denmark}

Description: Is not covered in NAK. VOV has a range of questions.

Noise VOV2006-64, VOV2006-66, VOV2006-68, VOV2006-70, VOV2006-

74, VOV2006-76

Chemicals VOV2006-79

Indoor climate VOV2006-59, VOV2006-60, VOV2006-62

\section{Finland}

No data

\section{Norway}

No data

\section{Sweden}

Legal obligation of employers to measure.

Specific action plans and action concerning noise, chemicals, indoor climate etc.

\begin{tabular}{llllll}
\hline \multicolumn{5}{l}{ Specific action plans and action concerning noise, chemicals, indoor climate etc. } \\
\hline DK & FI & NO & SW & Total \\
\hline $\begin{array}{l}\text { Overall grade } \\
\text { 1. Relevance }\end{array}$ & A & - & - & - \\
2. Accuracy & A & - & - & - \\
2. Cross-country comparable & & & & \\
3. Availability across countries & & & - & - \\
3. Availability over time & C & - & - & - \\
Linking possibility & Yes & - & - & - \\
Source and ownership & VOV, NFA & - & - &
\end{tabular}

Source: DAMVAD and expert group, 2011.

\subsubsection{Preventive Actions Regarding Work Accidents}

- In 2010 there were 44,381 work accidents in Denmark. 166 caused amputations and 39 were fatal (www.at.dk). This off course has major implications for the health among employers as well as costs related to the accidents. There are several ways companies can try to avoid work accidents. This can relate to routine security reviews of the workplace or implementation of action plans but can also relate to investments in security equipment as well as maintenance, training etc.Does the company take preventive actions regarding avoiding work accidents?

\section{Denmark}

VOV2006-18, VOV2006-19, VOV2006-21, VOV2006-23, VOV2006-24, VOV2006-26, VOV2006-28, VOV2006-30

NAK-2005 has a range of questions on whether the employee has had an industrial injury. Relating to the company's preventitive measures, the indirect goals are as follows: 
- Have you recieved information on how your work can be done in a safe way?

NAK2005-122:?

NAK-2010 has four questions on safety culture:

- The management is encouraging the employees to participate in decisions which affect their safety.

NAK2010-12; 1:

- We who work here help each other to work in a safe way NAK2010-12; 2

- We who work here feel that minor accidents are part of our daily work NAK2010-12; 3

- The management accepts that the employees run risks when the working schedule is tight.

NAK2005-123; 1 og NAK2010-12; 4

- The management does not care whether work is done in a secure manner as long as it is done on time.

NAK2005-123; 2

\section{Finland}

WCB

Norway

No data.

\section{Sweden}

Legal obligation of employers to measure.

Preventive Actions Regarding Work Accidents

\begin{tabular}{|c|c|c|c|c|c|}
\hline & DK & FI & NO & sw & Total \\
\hline Overall grade & & & & & C \\
\hline 1. Relevance & A & B & - & - & C \\
\hline 2. Accuracy & A & $A$ & - & - & B \\
\hline \multicolumn{6}{|c|}{ 2. Cross-country comparable } \\
\hline \multicolumn{6}{|c|}{ 3. Availability across countries } \\
\hline 3. Availability over time & $\mathrm{C}$ & A & - & - & c \\
\hline Linking possibility & Yes & No & - & - & C \\
\hline Source and ownership & VOV, NAK, both NFA & WCB & - & - & \\
\hline Accessible data? & A & & & & \\
\hline
\end{tabular}

Source: DAMVAD and expert group, 2011.

\subsubsection{Physical Exercise}

A central aspect of general and physical well-being is the general health conditions which also influences the well-being at the work place as well as the general well-being and performance of the employee.

- Physical exercise has initially been a central aspect of promoting work environment because it is documented to bring positive physical effects 
and also increases mental resources (Ahonen, Hussi 2007). Does the work place in any way support the physical well-being of the employee in terms of giving access to or performing physical exercise in relation to the work place?

\section{Denmark}

Description: Is not covered in VOV

- Within the past year, have you been offered health promotion via your workplace? And have you used these offers? Response category 3 - exercise facilities; response category 4 - weekly exercise offers.

\section{Finland}

SWBS

\section{Norway}

No data.

\section{Sweden}

No data

\begin{tabular}{llllll} 
Physical exercise & \multicolumn{1}{l}{} & & \\
\hline & DK & FI & NO & SW & Total \\
\hline $\begin{array}{l}\text { Overall grade } \\
\text { 1. Relevance }\end{array}$ & A & B & - & & C \\
2. Accuracy & A & A & - & - & C \\
$\begin{array}{l}\text { 2. Cross-country comparable } \\
\text { 3. Availability across countries }\end{array}$ & & & & B \\
3. Availability over time & C & A & - & & \\
Linking possibility & Yes & No & - & - & C \\
Source and ownership & NAK, NFA & SWBS & - & - & C \\
Accessible data? & A & & & & \\
\hline
\end{tabular}

Source: DAMVAD and expert group, 2011.

\subsubsection{Health Checks}

An aspect of health promotion policies in workplaces refers to a general health promotion policy, and it is now common to give the employees access to health checks. This is expected to promote workability as well as promoting loyalty towards the work place as long as it in reality is voluntary.

- Does the workplace provide health checks for the employees? 


\section{Denmark}

Description: Is not covered in VOV

- Within the past year, have you been offered health promotion via your workplace? And have you used these offers? Response category 6 - health check

\section{Finland}

SWBS

\section{Norway}

LKU

- Does your employer have a company health service?

\section{Sweden}

No data

Health Checks

\begin{tabular}{llllll}
\hline & DK & FI & NO & SW & Total \\
\hline $\begin{array}{l}\text { Overall grade } \\
\text { 1. Relevance }\end{array}$ & A & B & C & & C \\
$\begin{array}{l}\text { 2. Accuracy } \\
\text { 2. Cross-country comparable }\end{array}$ & A & A & C & - & C \\
$\begin{array}{l}\text { 3. Availability across countries } \\
\text { 3. Availability over time }\end{array}$ & C & A & A & - & C \\
Linking possibility & Yes & No & NO & - & C \\
Source and ownership & NAK, NFA & SWBS & Norwegian level of living & - & C \\
& & & condition survey - work- & \\
Accessible data? & & & ing environment, SSB & &
\end{tabular}

Source: DAMVAD and expert group, 2011.

\subsubsection{Rehabilitation Courses, Medical Treatment, Intoxicant Programs etc.}

In recent years the importance of health promotion programs directed towards employees has increased. This is part of a proactive taking care of the health of the employees which is expected to yield positive returns for the companies due to lower absenteeism and higher productivity among employees as well as promoting the health of the employees.

- Does the work place offer health promotion activities to the employees including medical care?

\section{Denmark}

Description: Is not covered in VOV 
- Within the past year, have you been offered health promotion via your workplace? And have you used these offers? Response category 5 - treatment scheme (physiotherapy, psychologist and the like).

NAK2010-9:

\section{Finland}

SWBS

WHS: QL21

\section{Norway}

No data

\section{Sweden}

No data

Rehabilitation courses, medical treatment, intoxicant programs etc.

\begin{tabular}{|c|c|c|c|c|c|}
\hline & DK & FI & NO & sw & Total \\
\hline Overall grade & & & & & C \\
\hline 1. Relevance & A & B & - & - & C \\
\hline 2. Accuracy & A & $A$ & - & - & B \\
\hline \multicolumn{6}{|c|}{ 2. Cross-country comparable } \\
\hline \multicolumn{6}{|c|}{ 3. Availability across countries } \\
\hline 3. Availability over time & C & $\begin{array}{l}\text { SWBS: A } \\
\text { WHS: B }\end{array}$ & - & - & C \\
\hline Linking possibility & Yes & No & - & - & C \\
\hline Source and ownership & NAK, NFA & $\begin{array}{l}\text { SWBS } \\
\text { WHS }\end{array}$ & - & - & \\
\hline Accessible data? & A & & & - & \\
\hline
\end{tabular}

Source: DAMVAD and expert group, 2011.

\subsection{Indicators Regarding Physical Conditions and Exposures}

\subsubsection{Light}

There is a known relationship between ranges of illnesses and working late hours - this relationship is sometimes hypothesised to be caused by the lack of sunlight. Further, too little light can imply risks of working accidents. The lack of light or too much light as well as the use of computers and screens can be stressing and imply difficult working conditions.

- Does the light give you optimal working conditions? 


\section{Denmark}

- Do you have problems with the light on your workplace? VOV2006-61

- Are you exposed to poor lighting? (to weak or to blinding) NAK2005$112 ; 8$

\section{Finland}

WHS: QH10

\section{Norway}

Description: The living condition survey (population sample) has several questions regarding self-reported work-related health problems. The data can be aggregated for occupational groups, industries or sectors.

Questions:

- Are you, in your day-to-day work, exposed to poor or blinding light or irritating reflections?

\section{Sweden}

Description: The question is originally used for measuring employee attitudes but the content of the question could nevertheless be used as indicator for company practise. The latter indicator may not provide an extensive definition of the above overall indicator but it could serve as proxy and be combined with other aspects.

Questions:

- Are you exposed to poor lighting (too weak or glaring). WES

\begin{tabular}{|c|c|c|c|c|c|}
\hline & DK & FI & No & sw & Total \\
\hline Overall grade & & & & & B \\
\hline 1. Relevance & A & B & B & B & B \\
\hline 2. Accuracy & A & A & A & A & A \\
\hline $\begin{array}{l}\text { 2. Cross-country } \\
\text { comparable }\end{array}$ & & & & & A \\
\hline $\begin{array}{l}\text { 3. Availability } \\
\text { across countries }\end{array}$ & & & & & B \\
\hline 3. Availability over time & B & B & & B & C \\
\hline Linking possibility & A & No & $\begin{array}{l}\mathrm{B} \text { (Only to } \\
\text { persons) }\end{array}$ & A & B \\
\hline Source and ownership & $\begin{array}{l}\text { VOV/NAK } \\
\text { National research } \\
\text { centre for the work- } \\
\text { ing environment }\end{array}$ & WHS & $\begin{array}{l}\text { Norwegian Living } \\
\text { Survey, Statictics } \\
\text { Norway }\end{array}$ & WES & \\
\hline Accessible data & yes & Yes & Yes & Yes & A \\
\hline
\end{tabular}

Source: DAMVAD and expert group, 2011. 


\subsubsection{Noise}

Noise can imply unpleasant working conditions as well as be damaging to the hearing capabilities of the employees. Too high a level of noise can cause hearing problems, tinnitus etc.

What is the level of noise in the workplace?

\section{Denmark}

Questions:

- Do you experience annoying noises in rooms where there are many people at the same time (e.g. workshops, factory floors, large open office areas, institutions etc.)? VOV2006-65

- Do you expirience noise from ventilation, computer equipment, other peoples phonecalls etc. At your work place? VOV2006-67

- Are you exposed to noise coming from outside your work place (e.g. from the street, traffic or noise from other rooms? VOV2006-69

- Are any employees exposed to hearing damaging noise (over 80dB(A) which makes it necessary to significantly increase ones voice) from e.g. machines, working processes and tools in your workplace? VOV2006-72

- Are any employees exposed to hearing damaging noise from machines in your workplace? VOV2006-73

- Are any employees working with noisy hand tools in your workplace (e.g. angle grinder, drilling hammer, circular saw, compressed air tools, welding, etc.)? VOV2006-72

- Have you been exposed to noise so loud that you had to raise your voice to communicate? NAK 2005-112; 1

- Are you exposed to noise so loud that you have to yell in order to communicate with a person standing right next to you? NAK 2005-112; 2 og NAK2010-10;1

\section{Finland}

WHS: GH1, H1T

EWCS: Q23B

\section{Norway}

Questions: 
- Are you, in your day-to-day work, exposed to noise so loud that you have to stand next to someone and shout in order to be heard?

\section{Sweden}

Description: The question is originally used for measuring employee attitudes but the content of the question could nevertheless be used as indicator for company practice. The latter indicator may not provide an extensive definition of the above overall indicator but it could serve as proxy and be combined with other aspects

Questions:

- Are you exposed to noise that is so loud that you cannot converse in a normal tone of voice? (WES)

\begin{tabular}{|c|c|c|c|c|c|}
\hline & DK & FI & No & sw & Total \\
\hline Overall grade & & & & & B \\
\hline 1. Relevance & A & B & A & B & B \\
\hline 2. Accuracy & A & A & A & A & A \\
\hline $\begin{array}{l}\text { 2. Cross-country } \\
\text { comparable }\end{array}$ & & & & & A \\
\hline $\begin{array}{l}\text { 3. Availability across } \\
\text { countries }\end{array}$ & & & & & B \\
\hline $\begin{array}{l}\text { 3. Availability over } \\
\text { time }\end{array}$ & B & $B, C$ & & B & C \\
\hline Linking possibility & A & No & $\begin{array}{l}\text { B(Only to } \\
\text { persons) }\end{array}$ & A & B \\
\hline $\begin{array}{l}\text { Source and owner- } \\
\text { ship }\end{array}$ & $\begin{array}{l}\text { VOV/NAK } \\
\text { National research } \\
\text { centre for the } \\
\text { working environ- } \\
\text { ment }\end{array}$ & WHS/EWCS & $\begin{array}{l}\text { Norwegian } \\
\text { Living Survey, } \\
\text { Statictics Nor- } \\
\text { way }\end{array}$ & WES & \\
\hline Accessible data & Yes & Yes & Yes & Yes & A \\
\hline
\end{tabular}

Source: DAMVAD and expert group, 2011.

\subsubsection{Temperature}

High and low working temperatures imply that employees can have difficulties regarding the general health state among the employees. Furthermore, it can cause a bad working climate in terms of unpleasant working conditions with too high, too low or changing working temperature.

- Is the temperature at the work place high, low or shifting? 


\section{Denmark}

Questions:

- What have you done to avoid problems with heat, cold or draft in the workplace within the past three years?

Vov2006-59

- Are you exposed to heat which makes you sluggish or sleepy?

NAK 2005-112; 6

\section{Finland}

WHS: QH9A,B

EWCS: Q23C-D

\section{Norway}

Questions:

- Are you, in your day-to-day work, exposed to heat, i.e. temperatures of approx. 28 degrees Celsius or higher?

- Are you, in your day-to-day work, exposed to cold, i.e. working outdoors in the winter, or working in cold rooms, etc.?

\section{Sweden}

The question was originally used for measuring employee attitudes but the content of the question could nevertheless be used as an indicator for company practice. The latter indicator may not provide an extensive definition of the above overall indicator but it could serve as a proxy and be combined with other aspects.

Questions:

WES Cold (outdoor work in winter, work in chilled room or the like). 


\begin{tabular}{|c|c|c|c|c|c|}
\hline & DK & $\mathrm{FI}$ & NO & SE & Total \\
\hline Overall grade & & & & & B \\
\hline 1. Relevance & B & B & A & B & C \\
\hline 2. Accuracy & A & A & A & A & A \\
\hline \multicolumn{6}{|l|}{$\begin{array}{l}\text { 2. Cross-country } \\
\text { comparable }\end{array}$} \\
\hline \multicolumn{6}{|l|}{$\begin{array}{l}\text { 3. Availability across } \\
\text { countries }\end{array}$} \\
\hline $\begin{array}{l}\text { 3. Availability over } \\
\text { time }\end{array}$ & B & $B, C$ & B & B & B \\
\hline Linking possibility & A & No & $\begin{array}{l}\text { B (only to } \\
\text { persons) }\end{array}$ & A & B \\
\hline $\begin{array}{l}\text { Source and owner- } \\
\text { ship }\end{array}$ & $\begin{array}{l}\text { VOV/NAK } \\
\text { National research } \\
\text { centre for the } \\
\text { working environ- } \\
\text { ment }\end{array}$ & WHS/EWCS & $\begin{array}{l}\text { Norwegian } \\
\text { Living Survey, } \\
\text { Statistics Nor- } \\
\text { way }\end{array}$ & WES & \\
\hline Accessible data & Yes & Yes & Yes & Yes & $A$ \\
\hline
\end{tabular}

Source: DAMVAD and expert group, 2011.

\subsubsection{High amount of Repetition of Motion}

Repetition of motion can take many forms. One well-known example is that of the work carried out in large butcheries. Another example may be that of secretaries or other people typing on computers for many hours. A high amount of repetition in motion implies that employees risk physical attrition.

- Does the work imply that the employees are exposed to a high amount of repetition in motion?

\section{Denmark}

Questions:

- Are there employees who do repeated work in your workplace? (e.g. computer work, packing or longer sessions of grinding or polishing? VOV2006-50

- How large is the part of your total working hours where you work in front of a computer? NAK2005-109

- How large is the part of your total working hours where you work with a computer mouse? NAK2005-110

- How many hours per week do you spend using a computer? NAK2010-8

- Does your work entail doing the same finger movements many times per minute (e.g. keyboard typing work) 
- Does your work entail doing the same arm movements many times per minute? (e.g. packing, mounting, cutting)

NAK2005-124; 9 og NAK2010-14; 7

\section{Finland}

WHS: QF10

EWCS: Q24E

\section{Norway}

Questions:

- Does your work involve repeated movements with just one of your hands or arms?

\section{Sweden}

The questions are originally used for measuring employee attitudes but the content of the questions could nevertheless be used as indicators for company practise. The latter indicators may not provide an extensive definition of the above overall indicator but it could serve as proxies and be combined with other aspects.

Questions:

- Does your work require you to perform only repetitive work movements at least twice every minute?

WES

- Do you sometimes work in a sitting position? For how long without interruption?

WES

\begin{tabular}{|c|c|c|c|c|c|}
\hline & DK & FI & NO & SE & Total \\
\hline Overall grade & & & & & B \\
\hline 1. Relevance & A & B & B & B & C \\
\hline 2. Accuracy & A & A & A & A & $A$ \\
\hline 2. Cross-country comparable & & & & & A \\
\hline \multicolumn{6}{|l|}{ 3. Availability across countries } \\
\hline 3. Availability over time & B & $\mathrm{B}, \mathrm{C}$ & B & B & $\mathrm{C}$ \\
\hline Linking possibility & A & No & $\mathrm{B}$ (only to persons) & A & B \\
\hline Source and ownership & $\begin{array}{l}\text { VOV/NAK } \\
\text { National re- } \\
\text { search centre for } \\
\text { the working } \\
\text { environment }\end{array}$ & WHS, EWCS & $\begin{array}{l}\text { Norwegian Living } \\
\text { Survey, Statistics } \\
\text { Norway }\end{array}$ & WES & \\
\hline Accessible data & Yes & Yes & Yes & Yes & $A$ \\
\hline
\end{tabular}

Source: DAMVAD and expert group, 2011. 


\subsubsection{Work Involves Simultaneous Lifting and Suboptimal Movement/Positioning}

Between 40 and 60 per cent of the Norwegian working population with musculoskeletal complaints report that these wholly or partly are related to their job, but there are major differences between occupational groups.

- Does the work imply that the employees are exposed to a high amount of repetition in motion?

\section{Denmark}

Questions:

- Are any employees performing heavy lifts in the workplace? VOV2006-48

- Are any employees doing physically demanding work in your workplace? VOV2006-53

- Does your work entail working with your back severely stooping without supporting with your hands and arms? NAK2005-124; 3 og NAK2010-14; 3

- Does your work entail that you twist and bend your back several times per hour? NAK2005-124; 4 og NAK2010-14; 4

- Does your work entail having your arms lifted in or above shoulder level? NAK2005-124; 5 og NAK2010-14; 5

- Does your work entail you working with your neck severely stooping? NAK2005-124; 6

- Ofyour total working time, how much do you spend pushing and pulling? NAK2005-129 og NAK2010-14; 9

- Of your total working time, how much time do you spend carrying or lifting? NAK2005-127 og NAK2010-14; 10

- What does what you carry or lift usually weigh? NAK2005-128 og NAK2010-15

- How is pushing and pulling typically perceived? NAK2005-130

\section{Finland}

WHS: QF3b, F6

EWCS: Q24A,C 


\section{Norway}

Questions:

- Do you work in those positions with your back twisted?[Yes/no]

- When working in those positions, do you need to lift anything that weighs more than $10 \mathrm{~kg} / 20 \mathrm{~kg}$ ?

\section{Sweden}

The questions are originally used for measuring employee attitudes but the content of the questions could nevertheless be used as indicators for company practice. The latter indicators may not provide an extensive definition of the above overall indicator but it could serve as proxies and be combined with other aspects

Questions:

- Do you sometimes work bending forward without supporting yourself with your hands or arms?

WES

- Do you sometimes work in a twisted posture?

WES

- Do you sometimes work with your hands raised to the level of your shoulders or higher?

WES

- Do you use a car at work? How many working hours are spent in the car?

WES

- Do you work with one of the following machines or equipment at least one fourth of your working time?

WES

a) Hand-held machines or machines that can be pushed or pulled along

b) Movable machines such as those that can be sit in and driven but not buses or cars

c) Stationary machines or process systems for manufacturing, processing, transport or packaging

- Do you have to lift at least $15 \mathrm{kgs}$ several times a day? WES 


\begin{tabular}{|c|c|c|c|c|c|}
\hline & DK & FI & NO & SE & Total \\
\hline Overall grade & & & & & B \\
\hline 1. Relevance & A & B & A & B & B \\
\hline 2. Accuracy & B & A & A & A & A \\
\hline $\begin{array}{l}\text { 2. Cross-country } \\
\text { comparable }\end{array}$ & A & & & & A \\
\hline \multicolumn{6}{|l|}{$\begin{array}{l}\text { 3. Availability across } \\
\text { countries }\end{array}$} \\
\hline 3. Availability over time & B & $\mathrm{B}, \mathrm{C}$ & B & B & C \\
\hline Linking possibility & A & No & $\begin{array}{l}\text { B (only to } \\
\text { persons) }\end{array}$ & A & B \\
\hline Source and ownership & $\begin{array}{l}\text { VOV/NAK } \\
\text { National research } \\
\text { centre for the } \\
\text { working environ- } \\
\text { ment }\end{array}$ & $\begin{array}{l}\text { WHS, } \\
\text { EWCS }\end{array}$ & $\begin{array}{l}\text { Norwegian Living } \\
\text { Survey, Statistics } \\
\text { Norway }\end{array}$ & WES & \\
\hline Accessible data & Yes & Yes & Yes & Yes & A \\
\hline
\end{tabular}

Source: DAMVAD and expert group, 2011.

\subsubsection{Work Involves Static Loads}

Static loads include standing still or walking much in the same position, e.g. with arms raised. Static workloads on muscles have a welldocumented relation to muscle pain, back pain, neck pain, pain in the arms and shoulders, etc.

- Does the work imply that the employees are exposed to a high amount of repetition in motion?

\section{Denmark}

Description: Is not covered in VOV. Only NAK covers this subject directly: Questions:

NAK2005-124; 1 and NAK2010-14; 1: Does your work entail you sitting down?

NAK2005-124; 2 and NAK2010-14; 2: Does your work entail standing in the same spot?

NAK2005-124; 10 and NAK2010-14; 8: Does your work entail squatting or kneeling when you work?

\section{Finland}

WHS: QF3B, F1

EWCS: Q24C

\section{Norway}

Questions: 
- Do you need to squat or kneel in the course of your work?

- Do you work standing up?

- Do you work with your hands raised to shoulder height or higher?

- Do you work in positions where you are leaning forward without supporting yourself on your hands or arms?

- Do you work with your head bent forward?

\section{Sweden}

No further remarks.

Work Involves Static Loads

\begin{tabular}{|c|c|c|c|c|c|}
\hline & DK & FI & NO & SE & Total \\
\hline Overall grade & & & & & c \\
\hline 1. Relevance & A & B & $A$ & B & B \\
\hline 2. Accuracy & B & A & A & A & $A$ \\
\hline $\begin{array}{l}\text { 2. Cross-country compa- } \\
\text { rable }\end{array}$ & A & & & & $A$ \\
\hline \multicolumn{6}{|l|}{$\begin{array}{l}\text { 3. Availability across } \\
\text { countries }\end{array}$} \\
\hline 3. Availability over time & B & $\mathrm{B}, \mathrm{C}$ & B & B & $\mathrm{C}$ \\
\hline Linking possibility & A & No & c & A & C \\
\hline Source and ownership & $\begin{array}{l}\text { NAK } \\
\text { National research } \\
\text { centre for the } \\
\text { working environ- } \\
\text { ment }\end{array}$ & $\begin{array}{l}\text { WHS, } \\
\text { EWCS }\end{array}$ & $\begin{array}{l}\text { Norwegian Living } \\
\text { Conditions, } \\
\text { Statistics Norway }\end{array}$ & WES & \\
\hline Accessible data & Yes & Yes & Yes & No & B \\
\hline
\end{tabular}

Source: DAMVAD and expert group, 2011.

\subsubsection{Production or Use of Certain Chemicals}

If the work implies working with chemicals, this involves a risk concerning the health of the employees. Chemicals can be both fatal and involve permanent external as well as internal injuries. Chemicals can cause short term illness but can also have long term effects for the health.

- Do you consider yourself above normal exposure to certain chemicals (skin contact/breathing/eye contact)?

\section{Denmark}

Questions:

- Are any employees at your workplace exposed to chemicals, toxic fumes, gasses, smoke or dust from materials or processes - or do any have wet work?

VOV2006-78: 
- Does your skin have contact with cleanser and/or disinfectants? NAK2005-112; 9 og NAK2010-10; 4:

- Does your skin have contact with protective gloves made from plastic or rubber? NAK2005-112; 10 :

- Are you exposed to solvent fumes? (e.g. from paint, laquer, glue or degreasing products) NAK2005-113; 1 :

- Are you exposed to tobacco smoke from other people's smoking? NAK2005-113; 2:

- How large a part of your total working hours where your hands are wet or moist? NAK2005-114; 1 and NAK2010-10; 5:

- How large a part of your total working hours do you work with dusty materials? (e.g. straw, milling) NAK2005-114; 4:

- In your workplace, do you work with materials marked as dangerous? (an orange label with a black cross, flame, test tube or skull) NAK2005-115; 1 :

- Do you work with isocyanats at your workplace? (you will know from your safety organization) NAK2005-115; 2:

- Do you work with epoxy in your workplace? (you will know from your safety organization) NAK2005-115; 4:

\section{Finland}

- WHS: QS1

- EWCS: Q23G

\section{Norway}

No information available

\section{Sweden}

- Are you exposed to: WES

a) Oil or cutting fluids (in contact with your skin)

b) Acid or basic (corroding) chemical compounds.

c) Cleaning agents and/or disinfectants (in contact with your skin).

d) Water which comes in direct contact with your skin several times an hour (incl. washing your hands).

e) Human secretions like saliva, blood, urine, human feces or vomit. 


\begin{tabular}{|c|c|c|c|c|c|}
\hline & DK & FI & NO & SE & Total \\
\hline Overall grade & & & & & C \\
\hline 1. Relevance & $A$ & B & & B & B \\
\hline 2. Accuracy & $A$ & $A$ & & $A$ & B \\
\hline $\begin{array}{l}\text { 2. Cross-country compara- } \\
\text { ble }\end{array}$ & & & & & B \\
\hline \multicolumn{6}{|l|}{$\begin{array}{l}\text { 3. Availability across } \\
\text { countries }\end{array}$} \\
\hline 3. Availability over time & B & $B, C$ & & B & c \\
\hline Linking possibility & A & No & & $A$ & B \\
\hline Source and ownership & $\begin{array}{l}\text { NAK and VOV } \\
\text { National research } \\
\text { centre for the } \\
\text { working environ- } \\
\text { ment }\end{array}$ & WHS, EWCS & & WES & \\
\hline Accessible data & Yes & Yes & & Yes & B \\
\hline
\end{tabular}

Source: DAMVAD and expert group, 2011.

\subsubsection{Exposure to Smoke, Dust, Fumes (Skin Contact/Breathing/Eye Contact)}

Inhaling particles, dust, smoke etc. imply a variety of risks. This can have consequences for the general well-being and work satisfaction but can also imply the risk of the health of employees, both regarding short term illness but also in the longer run concerning cancer or other airways diseases.

- Does the work well-being include a risk of inhaling unhealthy particles etc. through the human airways?

\section{Denmark}

They refer to the same question as the above:

Questions:

- Are any employees in the workplace exposed to chemicals, fumes, gasses, smoke or dust from materials or processes - or does anyone do wet work? VOV2006-78:

- Does your skin have contact with cleaners and/or disinfectants? NAK2005-112; 9 og NAK2010-10; 4:

- Does your skin have contact with protection gloves made my plastic or rubber?

NAK2005-112; 10 
- Are you being exposed to solvent fumes? (e.g. paint, laquer, glue, degreasing products)

NAK2005-113; 1

- Are you exposed to tobacco smoke from other peoples smoking? NAK2005-113; 2

- How large a part of your total working hours where your hands are wet or moist?

NAK2005-114; 1 og NAK2010-10; 5

- NAK2005-114; 4: How large a part of your total working hours do you work with dusty materials? (e.g. straw, milling)

- NAK2005-115; 1: In your workplace, do you work with materials marked as dangerous? (an orange label with a black cross, flame, test tube or skull)

- NAK2005-115; 2: Do you work with isocyanats at your workplace? (you will know from your safety organization)

- NAK2005-115; 4: Do you work with epoxy in your workplace? (you will know from your safety organization)

\section{Finland}

WHS: QH2

EWCS: Q23E

\section{Norway}

LKU

- Are you, in your day-to-day work, exposed to skin contact with cleaning products, disinfectants, solvents or other degreasing agents?

\section{Sweden}

Questions:

- Are any of the following noticeably present that you can see or smell in your workplace?

WES

a) Dust from metals, stone, quartz, cement, asbestos, mineral wool, or the like.

b) Dust from textiles, wood, flour, animals or plants

c) Chemicals (gases, vapors, solvents, pesticides or plastic chemicals)

d) Tobacco smoke from others' smoking (passive smoking) 


\begin{tabular}{|c|c|c|c|c|c|}
\hline & DK & $\mathbf{F I}$ & NO & SE & Total \\
\hline Overall grade & & & & & C \\
\hline 1. Relevance & A & B & B & B & C \\
\hline 2. Accuracy & A & $A$ & $A$ & $A$ & A \\
\hline \multicolumn{6}{|l|}{$\begin{array}{l}\text { 2. Cross-country compara- } \\
\text { ble }\end{array}$} \\
\hline \multicolumn{6}{|l|}{$\begin{array}{l}\text { 3. Availability across } \\
\text { countries }\end{array}$} \\
\hline 3. Availability over time & B & $B, C$ & A & B & c \\
\hline Linking possibility & A & No & No & A & c \\
\hline Source and ownership & $\begin{array}{l}\text { NAK and VOV } \\
\text { National research } \\
\text { centre for the } \\
\text { working environ- } \\
\text { ment }\end{array}$ & $\begin{array}{l}\text { WHS, } \\
\text { EWCS }\end{array}$ & LKU & WES & \\
\hline Accessible data & Yes & Yes & Yes & Yes & A \\
\hline
\end{tabular}

Source: DAMVAD and expert group, 2011.

\subsubsection{Work Accident Risks in Terms of Using Technical Equipment and Machinery}

Some jobs are performed in settings where there is a high risk of work accidents as a consequence of using technical machinery. This can imply risks of cuts and wounds and can in some incidents lead to amputation of body parts.

- Does the work include working with technical equipment and machinery which imply a general risk for work accidents?

\section{Denmark}

Questions:

- Do you work with machines in your workplace? VOV2006-20:

- Do you work with hand tools in your workplace? VOV2006-22:

- Do you work with mobile machines and other means of transportation in your workplace?

VOV2006-27:

NAK does not have questions regarding the risk of accidents related to the use of machines and equipment. 


\section{Finland}

EWAS

\section{Norway}

Description: We have two potential sources for this information on general risk for work accidents, neither of which, however, specifies that the risk is caused by technical equipment and machinery.

The Labour Force Survey 2007 ad hoc module has the following question (Q16d):

- Would you say that at your workplace you have particular exposure to risk of accidents that can adversely affect your physical health? (Yes/No)

The Norwegian level of living condition survey - working environment, Statistics Norway, has the following question:

- How would you evaluate the risk of accident in your own work? (scale with 3 categories)

\section{Sweden}

- Are you exposed to vibrations that make your whole body shake and vibrate (for example, from a tractor, forklift, or other work machine). WES

- Are you exposed to vibrations from hand-held machines or tools. WES

\begin{tabular}{|c|c|c|c|c|c|}
\hline & DK & FI & NO & SE & Total \\
\hline Overall grade & & & & & C \\
\hline 1. Relevance & A & A & C & B & B \\
\hline 2. Accuracy & B & A & B & A & B \\
\hline \multicolumn{6}{|l|}{$\begin{array}{l}\text { 2. Cross-country compa- } \\
\text { rable }\end{array}$} \\
\hline \multicolumn{6}{|l|}{$\begin{array}{l}\text { 3. Availability across } \\
\text { countries }\end{array}$} \\
\hline 3. Availability over time & B & A & B & B & C \\
\hline Linking possibility & A & No & & A & B \\
\hline Source and ownership & $\begin{array}{l}\text { NAK and VOV } \\
\text { National research } \\
\text { centre for the } \\
\text { working environ- } \\
\text { ment }\end{array}$ & EWAS & $\begin{array}{l}\text { Norwegian Living } \\
\text { Conditions, } \\
\text { Statistics Norway } \\
\text { Labour Force } \\
\text { survey }\end{array}$ & WES & \\
\hline Accessible data & Yes & Yes & Yes & Yes & $A$ \\
\hline
\end{tabular}

Source: DAMVAD and expert group, 2011. 


\subsubsection{Work Includes Risk of Falling from Heights}

Construction workers are examples of personnel having a job, where there is a large risk of falling from heights. Falling can be fatal or cause disabilities.

- Does the work include working with technical equipment and machinery which imply a general risk for work accidents?

\section{Denmark}

Questions:

- Is there a risk of falling from hights at your workplace? VOV2006-25:

NAK does not have questions specifically regarding the risk of fall injuries.

\section{Finland}

EWAS

\section{Norway}

No data available

\section{Sweden}

No data available

\begin{tabular}{|c|c|c|c|c|c|}
\hline & DK & FI & NO & SE & Total \\
\hline Overall grade & & & & & C \\
\hline 1. Relevance & A & A & & & B \\
\hline 2. Accuracy & B & A & & & C \\
\hline $\begin{array}{l}\text { 2. Cross-country compara- } \\
\text { ble }\end{array}$ & C & & & & C \\
\hline $\begin{array}{l}\text { 3. Availability across coun- } \\
\text { tries }\end{array}$ & C & & & & C \\
\hline 3. Availability over time & B & A & & & C \\
\hline Linking possibility & A & No & & & C \\
\hline Source and ownership & $\begin{array}{l}\text { NAK and VOV } \\
\text { National research } \\
\text { centre for the } \\
\text { working environ- } \\
\text { ment }\end{array}$ & EWAS & & & \\
\hline Accessible data & Yes & Yes & No & No & B \\
\hline
\end{tabular}

Source: DAMVAD and expert group, 2011. 


\subsubsection{Work Includes Traffic Risk}

Moving in traffic most of the day increases the risk of being part of a traffic accident, and many different jobs involve this risk, e.g. bus driver, lorry driver, taxi driver, post man, police officer etc. Furthermore, jobs performed in the traffic - e.g. construction workers, road construction workers etc. - are also at risk.

- Does the work imply risk of traffic accidents?

\section{Denmark}

Questions:

- Do you have employees working in traffic? VOV2006-29:

NAK does not have questions specifically regarding the risk of traffic accidents.

\section{Finland}

TVL

EWAS

\section{Norway}

Data not available (However, in the Labour Force Survey 2007 ad hoc module, there was a question whether the last occupational accident was a road traffic accident)

\section{Sweden}

Questions:

- Do you use a car at work? How many working hours are spent in the car?

WES 


\begin{tabular}{|c|c|c|c|c|c|}
\hline & DK & $\mathbf{F I}$ & No & SE & Total \\
\hline Overall grade & & & & & C \\
\hline 1. Relevance & $A$ & A & C & B & B \\
\hline 2. Accuracy & C & A & C & A & C \\
\hline \multicolumn{6}{|l|}{$\begin{array}{l}\text { 2. Cross-country compa- } \\
\text { rable }\end{array}$} \\
\hline \multicolumn{6}{|l|}{$\begin{array}{l}\text { 3. Availability across } \\
\text { countries }\end{array}$} \\
\hline 3. Availability over time & B & $A$ & B & B & C \\
\hline Linking possibility & A & C & B & A & B \\
\hline Source and ownership & $\begin{array}{l}\text { VOV } \\
\text { National research } \\
\text { centre for the } \\
\text { working environ- } \\
\text { ment }\end{array}$ & TVL, EWAS & $\begin{array}{l}\text { Labour Force } \\
\text { Survey }\end{array}$ & WES & \\
\hline Accessible data & Yes & Yes & Yes & Yes & A \\
\hline
\end{tabular}

Source: DAMVAD and expert group, 2011.

\subsection{Indicators Regarding Psychosocial Conditions}

\subsubsection{Freedom to Decide one's Own Work Tasks}

\section{Denmark}

Do you participate in planning of your own work? NAK2005-131 and NAK2010-20

Do you have any influence on the amount of work you do? NAK2005$135 ; 8$

Do you have any influence in WHAT you do at work? NAK2005-135; 9

\section{Finland}

EWB

WHS: QJ12,13

You can take a break when you wish EWCS

Are you able to choose or change your own tasks? EWCS

Norway:

"To what extent are you free to decide your own tasks? Do you decide to a very great extent, to a great extent, to some extent, not really or hardly at all?"

"To what extent are you free to decide how to go about doing your work?"

"To what extent can you influence decisions that are important to your work?" 


\section{Sweden}

"Are you involved in planning your work (for example, what is to be done, how it is to be done, or who is to work with you)?" WES

"Is it possible for you to decide on your own when various tasks are to be done (for example, by choosing to work a bit faster some days and taking it easier other days)?" WES

"I have considerable freedom for action without going to my manager to ask for permission" ECQ

"To what extent do you feel that you can make your own decisions concerning your work?" ECQ

"Do you have the authority to deal with problems arising in your work?" ECQ

"Do you feel there are any significant barriers to be able to work efficiently, and if so, are they... Control of details, Matters are not attended to in time, Rigid rules, Guidelines not clear, Decisions aren't taken quickly enough, Computer systems, Bureaucracy, Work routines, People only think about themselves, Organizational structure, Top management control, Workload, Lack of information lack of proper competence, Employee turnover" ECQ

"I can decide myself how to conduct my work", ECQ

\begin{tabular}{|c|c|c|c|c|c|}
\hline & DK & FI & No & SE & Total \\
\hline Overall grade & & & & & C \\
\hline 1. Relevance & A & A & A & B & A \\
\hline 2. Accuracy & A & A & A & A & A \\
\hline $\begin{array}{l}\text { 2. Cross-country } \\
\text { comparable }\end{array}$ & & & & & B \\
\hline $\begin{array}{l}\text { 3. Availability } \\
\text { across countries }\end{array}$ & & & & & A \\
\hline $\begin{array}{l}\text { 3. Availability } \\
\text { over time }\end{array}$ & C & C & B & $\begin{array}{l}\text { B, WES } \\
\text { A, ECQ }\end{array}$ & C \\
\hline $\begin{array}{l}\text { Linking possibil- } \\
\text { ity }\end{array}$ & A & $\begin{array}{l}\text { EWB } \\
\text { WHS } \\
\text { EWCS: C }\end{array}$ & C & $\begin{array}{l}\text { WES: A } \\
\text { ECQ: C }\end{array}$ & C \\
\hline $\begin{array}{l}\text { Source and } \\
\text { ownership }\end{array}$ & $\begin{array}{l}\text { NAK, National } \\
\text { Research centre } \\
\text { for the Working } \\
\text { Environment }\end{array}$ & & $\begin{array}{l}\text { Norwegian level of } \\
\text { living condition } \\
\text { survey - working } \\
\text { environment, SSB }\end{array}$ & $\begin{array}{l}\text { WES: The Swedish } \\
\text { Work Environment } \\
\text { Survey. SCB and } \\
\text { Swedish Work } \\
\text { Environment } \\
\text { Authority } \\
\text { ECQ }\end{array}$ & \\
\hline Accessible data? & Yes & & Yes & Yes & \\
\hline
\end{tabular}

Source: DAMVAD and expert group, 2011. 


\section{Norway}

Can the data be linked to persons or companies e.g. by vat number? Within the file the exposure and outcome data are linked (cross-sectional data), we also have panel data where the same person is followed over time (three years intervals). Not possible to link to companies.

\subsubsection{Frames Allowing Deliverance of Quality Desired by one Self}

\section{Denmark}

Are you able to perform your work at a quality level that you are completely satisfied with? NAK2005-141; 4 og NAK2010-27; 4

\section{Finland}

No data

\section{Norway}

No data

\section{Sweden}

Nothing reported

\begin{tabular}{|c|c|c|c|c|c|}
\hline & DK & FI & NO & SE & Total \\
\hline Overall grade & & & & & C \\
\hline 1. Relevance & A & & & & $\mathrm{C}$ \\
\hline 2. Accuracy & $A$ & & & & $\mathrm{C}$ \\
\hline 2. Cross-country comparable & & & & & $\mathrm{C}$ \\
\hline 3. Availability across countries & & & & & $\mathrm{C}$ \\
\hline 3. Availability over time & $A$ & & & & $\mathrm{C}$ \\
\hline Linking possibility & A & & & & $\mathrm{C}$ \\
\hline Source and ownership & $\begin{array}{l}\text { NAK, National Research centre for } \\
\text { the Working Environment }\end{array}$ & & & & \\
\hline Accessible data? & Yes & - & & - & \\
\hline
\end{tabular}

Source: DAMVAD and expert group, 2011.

\subsubsection{Freedom to Organise the Day, Including Brakes}

\section{Denmark}

Not included

\section{Finland}

You can take a break when you wish EWCS 


\section{Norway}

"Are you free to choose when to take a break from your work: e.g. to stretch your legs or take a breather in some other way?"

\section{Sweden}

"How do you experience your work? Too little influence" WES

"How do you experience your work? Constrained and unfree", WES

"In the mains can you take short breaks at any time in order to talk?" WES

"Does your work occasionally require you to perform nothing but repetitive tasks several times per hour?" WES

"Is there any part of your work day when you do nothing but wait and remain prepared in case something might happen?" WES

\begin{tabular}{|c|c|c|c|c|c|}
\hline & DK & $\mathbf{F I}$ & NO & SE & Total \\
\hline Overall grade & & & & & C \\
\hline 1. Relevance & C & A & B & A & B \\
\hline 2. Accuracy & C & A & A & A & B \\
\hline $\begin{array}{l}\text { 2. Cross-country compa- } \\
\text { rable }\end{array}$ & & & & & A \\
\hline $\begin{array}{l}\text { 3. Availability across } \\
\text { countries }\end{array}$ & & & & & A \\
\hline 3. Availability over time & C & C & B & B & C \\
\hline Linking possibility & C & C & C & A & C \\
\hline Source and ownership & & & $\begin{array}{l}\text { Norwegian level of } \\
\text { living condition } \\
\text { survey - working } \\
\text { environment, SSB }\end{array}$ & $\begin{array}{l}\text { WES: The Swedish } \\
\text { Work Environment } \\
\text { Survey. SCB and } \\
\text { Swedish Work } \\
\text { Environment } \\
\text { Authority }\end{array}$ & \\
\hline Accessible data? & - & No & Yes & Yes & \\
\hline
\end{tabular}

Source: DAMVAD and expert group, 2011.

\subsubsection{Work at High Speed}

\section{Denmark}

Is it necessary to work very quickly? NAK2005-135; 1 og NAK2010-23; 5

\section{Finland}

And does your job involve working at a very high speed? EWCS

WHS: QJ2

WCB 


\section{Norway}

"How often do you have to work quickly?"

"How well does the following description fit your current job? ... There is normally not time to perform tasks properly"

\section{Sweden}

"Is it possible for you to set your own work tempo?" WES

\begin{tabular}{|c|c|c|c|c|c|}
\hline & DK & FI & No & SE & Total \\
\hline Overall grade & & & & & C \\
\hline 1. Relevance & A & B & A & B & B \\
\hline 2. Accuracy & A & A & A & A & A \\
\hline $\begin{array}{l}\text { 2. Cross-country } \\
\text { comparable }\end{array}$ & & & & & B \\
\hline $\begin{array}{l}\text { 3. Availability } \\
\text { across countries }\end{array}$ & & & & & A \\
\hline $\begin{array}{l}\text { 3. Availability over } \\
\text { time }\end{array}$ & C & C & B & B & C \\
\hline Linkable & A & C & C & A & C \\
\hline $\begin{array}{l}\text { Source and owner- } \\
\text { ship }\end{array}$ & $\begin{array}{l}\text { NAK, National } \\
\text { Research centre for } \\
\text { the Working } \\
\text { Environment }\end{array}$ & & $\begin{array}{l}\text { Norwegian level of } \\
\text { living condition } \\
\text { survey - working } \\
\text { environment, SSB }\end{array}$ & $\begin{array}{l}\text { WES: The Swedish } \\
\text { Work Environment } \\
\text { Survey. SCB and } \\
\text { Swedish Work } \\
\text { Environment } \\
\text { Authority }\end{array}$ & \\
\hline Accessible data? & Yes & & Yes & Yes & \\
\hline
\end{tabular}

Source: DAMVAD and expert group, 2011.

\subsubsection{Large Work Loads}

\section{Denmark}

Is your work unevenly distributed so that it can pile up? NAK2005-135; 2 and NAK2010-23; 1

How often does it occur that you do not accomplish all your work tasks? NAK2005-135; 3 og NAK2010-23; 2

Is it necessary to work late? NAK2005-135; 5 og NAK2010-23; 3:

\section{Finland}

No data

\section{Norway}

"How often do you have too much to do?" 
"Do you sometimes have so much to do that you have to miss lunch, work longer than your normal working hours or take work home with you?"

\section{Sweden}

"Is your work sometimes so stressful that you do not have time to talk or even think of anything other than work?" WES

"Do you sometimes have so much work to do that you have to skip lunch, work late, or take work home with you?" WES

"How do you experience your work? Far too much to do" WES

\begin{tabular}{|c|c|c|c|c|c|}
\hline & DK & $\mathbf{F I}$ & NO & SE & Total \\
\hline Overall grade & & & & & B \\
\hline 1. Relevance & A & & A & A & A \\
\hline 2. Accuracy & A & & A & A & A \\
\hline $\begin{array}{l}\text { 2. Cross-country } \\
\text { comparable }\end{array}$ & & & & & B \\
\hline $\begin{array}{l}\text { 3. Availability } \\
\text { across countries }\end{array}$ & & & & & B \\
\hline $\begin{array}{l}\text { 3. Availability over } \\
\text { time }\end{array}$ & A & & B & B & B \\
\hline Linkable & A & & C & A & B \\
\hline $\begin{array}{l}\text { Source and owner- } \\
\text { ship }\end{array}$ & $\begin{array}{l}\text { NAK, National } \\
\text { Research centre for } \\
\text { the Working } \\
\text { Environment }\end{array}$ & & $\begin{array}{l}\text { Norwegian level of } \\
\text { living condition } \\
\text { survey - working } \\
\text { environment, SSB }\end{array}$ & $\begin{array}{l}\text { WES: The Swedish } \\
\text { Work Environment } \\
\text { Survey. SCB and } \\
\text { Swedish Work } \\
\text { Environment } \\
\text { Authority }\end{array}$ & \\
\hline Accessible data? & Yes & - & Yes & Yes & \\
\hline
\end{tabular}

Source: DAMVAD and expert group, 2011.

\subsubsection{High Cognitive Demands}

\section{Denmark}

How often do you have to worry about other people's problems in your work? NAK2010-23; 6:

Does your work put you in emotionally draining situations? NAK2005135; 4

Is your work emotionally draining? NAK2005-136; 2 og NAK2010-25; 1:

Are you affected emotionally by your work? NAK2005-136;5 and NAK2010-25; 3

To what degree do you have to survey a large amount of information in order to carry out your work? NAK2005-136; 1 


\section{Finland}

WHS: QJ4

WCB

\section{Norway}

"How often does your job require you to learn new skills?"

\section{Sweden}

Does your work require your undivided attention and concentration? WES

How do you experience your work? Tasks too difficult? WES

How do you experience your work? Mentally stressful work? WES

Do you spend part of your workday comprehending or solving complex problems? WES

Does your job allow you opportunities to learn something new and develop in your occupation? WES

Does your work require any more classroom education or courses beyond (lower-secondary) compulsory or elementary school? WES

Besides education or courses, is there any on-the-job training or introductory training necessary to perform your job? WES

I have the skills/qualifications I need to carry out my assignments at work

I feel that I develop and expand my capabilities at work ECQ

New ideas are encouraged and given strong support ECQ

We often try out new methods and ways of thinking ECQ

I constantly benefit from the knowledge and experience of others ECQ

We are encouraged to share our knowledge and experiences ECQ

\begin{tabular}{|c|c|c|c|c|c|}
\hline & DK & FI & NO & SE & Total \\
\hline Overall grade & & & & & B \\
\hline 1. Relevance & A & B & B & A & B \\
\hline 2. Accuracy & A & A & A & A & A \\
\hline $\begin{array}{l}\text { 2. Cross-country } \\
\text { comparable }\end{array}$ & & & & & B \\
\hline $\begin{array}{l}\text { 3. Availability } \\
\text { across countries }\end{array}$ & & & & & A \\
\hline $\begin{array}{l}\text { 3. Availability } \\
\text { over time }\end{array}$ & C & $\begin{array}{l}\text { WHS: A } \\
\text { WCB: B }\end{array}$ & B & $\begin{array}{l}\text { B (WES) } \\
A(E C Q)\end{array}$ & B \\
\hline Linkable & A & C & C & $\begin{array}{l}\text { WES: A } \\
\text { ECQ: C }\end{array}$ & C \\
\hline $\begin{array}{l}\text { Source and } \\
\text { ownership }\end{array}$ & $\begin{array}{l}\text { NAK, National } \\
\text { Research } \\
\text { centre for the } \\
\text { Working } \\
\text { Environment }\end{array}$ & & $\begin{array}{l}\text { Norwegian level } \\
\text { of living condi- } \\
\text { tion survey- } \\
\text { working envi- } \\
\text { ronment, SSB }\end{array}$ & $\begin{array}{l}\text { WES: The Swedish Work } \\
\text { Environment Survey. SCB } \\
\text { and Swedish Work } \\
\text { Environment Authority } \\
\text { ECQ }\end{array}$ & \\
\hline Accessible data? & Yes & & Yes & Yes & \\
\hline
\end{tabular}

Source: DAMVAD and expert group, 2011. 


\subsubsection{Clarity of Expectations in Work}

\section{Denmark}

I clearly know what my areas of responsibility are: NAK2005-143; 1

\section{Finland}

\section{WHS: QJ24B}

Do you know what is expected of you at work EWCS Q51K

\section{Norway}

- How often is it unclear what is expected of you in your job?

- Do you sometimes have to perform tasks that you do not feel adequately trained to do?

\section{Sweden}

If your tasks feel difficult, do you have access to advice or help? WES To what extent do you agree with the following statements concerning you and your situation? ECQ

- I am familiar with the overall company goals

- I have clearly defined goals

- My individual goals are followed up

- In my work group our goals are regularly followed up

I understand what our values mean in my everday work ECQ

I am aware of what is important in order to make the company successful ECQ

In my work group we are organized in such a way that everyone knows who should be doing what ECQ

It is important for a manager to be able to give precise answers to the majority of questions that his/her employees may raise about their work ECQ 


\begin{tabular}{|c|c|c|c|c|c|}
\hline & DK & FI & NO & SE & Total \\
\hline Overall grade & & & & & B \\
\hline 1. Relevance & A & B & A & A & A \\
\hline 2. Accuracy & A & A & A & A & A \\
\hline $\begin{array}{l}\text { 2. Cross-country } \\
\text { comparable }\end{array}$ & & & & & B \\
\hline $\begin{array}{l}\text { 3. Availability across } \\
\text { countries }\end{array}$ & & & & & A \\
\hline 3. Availability over time & C & $\begin{array}{l}\text { WHS: B } \\
\text { EWCS: C }\end{array}$ & A & $\begin{array}{l}\text { WES: B } \\
\text { ECQ: A }\end{array}$ & B \\
\hline Linkable & A & C & C & $\begin{array}{l}\text { WES: A } \\
\text { ECQ: C }\end{array}$ & C \\
\hline Source and ownership & $\begin{array}{l}\text { NAK, National } \\
\text { Research centre for } \\
\text { the Working } \\
\text { Environment }\end{array}$ & & LKU & $\begin{array}{l}\text { WES: The Swedish } \\
\text { Work Environment } \\
\text { Survey. SCB and } \\
\text { Swedish Work } \\
\text { Environment } \\
\text { Authority } \\
\text { ECQ }\end{array}$ & \\
\hline Accessible data? & Yes & & ? & Yes & \\
\hline
\end{tabular}

Source: DAMVAD and expert group, 2011.

\subsubsection{Contradicting Demands}

\section{Denmark}

Conflicting demands are placed on me in my work: NAK2005-143; 2

\section{Norway}

"How often do you receive contradictory requests from two or more different people?"

"How often are you given tasks without being given sufficient tools and resources to complete them? How often do you have to do things that you think should be done in a different way?" 


\begin{tabular}{|c|c|c|c|c|c|}
\hline & DK & FI & No & SE & Total \\
\hline Overall grade & & & & & C \\
\hline 1. Relevance & A & & B & & B \\
\hline 2. Accuracy & A & & A & & B \\
\hline $\begin{array}{l}\text { 2. Cross-country compa- } \\
\text { rable }\end{array}$ & & & & & B \\
\hline $\begin{array}{l}\text { 3. Availability across } \\
\text { countries }\end{array}$ & & & & & C \\
\hline 3. Availability over time & C & & B & & C \\
\hline Linkable & A & & C & & C \\
\hline Source and ownership & $\begin{array}{l}\text { NAK, National } \\
\text { Research centre for } \\
\text { the Working } \\
\text { Environment }\end{array}$ & & $\begin{array}{l}\text { Norwegian level of } \\
\text { living condition } \\
\text { survey - working } \\
\text { environment, SSB }\end{array}$ & & \\
\hline Accessible data? & Yes & & Yes & & \\
\hline
\end{tabular}

Source: DAMVAD and expert group, 2011.

\subsubsection{Trust and Respect From Leadership}

\section{Denmark}

Ensure that the individual employee has good development opportunities? NAK2005-137; 1 og NAK2010-26; 1

Is your work recognized and valued by the management? NAK2005141; 1 og NAK 2010-27; 1

The management is confident that we do our work well NAK2010-28; 2

Our immediate manager takes our needs and views into consideration when making decisions. NAK2010-28; 5

Our immediate manager treats us with resepect and dignity. NAK201028; 6

\section{Finland}

WHS: QJ35

In general, your immediate manager/supervisor respects you as a person EWCS: Q58B

\section{Norway}

"How well does the following description fit your immediate superior?

Your immediate superior treats employees with trust and respect?"

"Do you get feedback from your superiors on how you have performed your work?"

"Does your immediate superior treat employees fairly and impartially?"

"Does your immediate superior value your achievements at work?"

Sweden: 
Does your superior (boss) ever express appreciation for your work? WES

If you think you have too much to do, is it possible for you to get in contact with your supervisor for setting of priorities? WES

How much confidence do you have in the managers at various levels within the company? ECQ

My manager...

a) creates efficiency

b) follows competitor's actions and the market situation on a regular basis

c) helps me to understand our unit's role in achieving company targets

d) finds creative and practical solutions to problems

Achievement and initiative

e) is decisive

$f)$ ensures that decisions taken are implemented

g) ensures that decisions and schedules are followed up

h) initiates activities to achieve better results

i) is consistent in demanding results and achieving goals

Customer responsive

j) make the most of customer/market opportunities

$k$ ) encourages us to practice service leadership

l) develops and supports long-term relationships with customers

$m$ ) makes sure that customer satisfaction is the focus of the team's efforts

People development

n) supports me if I take on added responsibility

o) gives me constructive feedback on my work performance

p) ensures that all employees are involved in planning, implementation and follow-up of activities

q) enables and supports my development

r) creates an open and trusting atmosphere in the unit

Personnel standards

s) is accessible/has time for me

t) is a good listener

u) .communicaties in a clear and comprehensive way

v) is open for constructive feedback

w) keeps his/her promises

x) creates positive energy in employees around him/her ECQ 
When I do a good job my contribution is recognized ECQ

\begin{tabular}{|c|c|c|c|c|c|}
\hline & DK & FI & NO & SE & Total \\
\hline Overall grade & & & & & C \\
\hline 1. Relevance & A & B & A & A & A \\
\hline 2. Accuracy & A & A & A & A & A \\
\hline $\begin{array}{l}\text { 2. Cross-country } \\
\text { comparable }\end{array}$ & & & & & B \\
\hline $\begin{array}{l}\text { 3. Availability across } \\
\text { countries }\end{array}$ & & & & & A \\
\hline 3. Availability over time & C & $\begin{array}{l}\text { WHS: B } \\
\text { EWCS: C }\end{array}$ & B & $\begin{array}{l}\text { WES: B } \\
\text { ECQ: A }\end{array}$ & C \\
\hline Linkable & A & C & C & A & C \\
\hline Source and ownership & & & $\begin{array}{l}\text { Norwegian level of } \\
\text { living condition } \\
\text { survey - working } \\
\text { environment, SSB }\end{array}$ & $\begin{array}{l}\text { WES: The Swedish } \\
\text { Work Environment } \\
\text { Survey. SCB and } \\
\text { Swedish Work } \\
\text { Environment } \\
\text { Authority } \\
\text { ECQ }\end{array}$ & \\
\hline Accessible data? & & & Yes & Yes & \\
\hline
\end{tabular}

Source: DAMVAD and expert group, 2011.

\subsubsection{Trust and Respect from Colleagues}

\section{Sweden}

How do you experience your work? Too little support and help from fellow workers and superiors? WES

How do you experience your work? Too isolated from others? WES

In my daily work there is a spirit and enthusiasm that is inspiring ECQ 


\begin{tabular}{|c|c|c|c|c|c|}
\hline & DK & FI & NO & SE & Total \\
\hline Overall grade & & & & & C \\
\hline 1. Relevance & & & & A & C \\
\hline 2. Accuracy & & & & A & C \\
\hline 2. Cross-country comparable & & & & & C \\
\hline 3. Availability across countries & & & & & c \\
\hline \multirow[t]{2}{*}{ 3. Availability over time } & & & & WES: B & C \\
\hline & & & & ECQ: A & \\
\hline \multirow[t]{2}{*}{ Linkable? } & & & & Yes WES & \\
\hline & & & & No ECQ & \\
\hline \multirow[t]{7}{*}{ Source and ownership } & & & & WES: The Swedish & \\
\hline & & & & Work Environment & \\
\hline & & & & Survey. SCB and & \\
\hline & & & & Swedish Work & \\
\hline & & & & Environment & \\
\hline & & & & Authority & \\
\hline & & & & $\mathrm{ECQ}$ & \\
\hline Accessible data? & & & & Yes & \\
\hline
\end{tabular}

Source: DAMVAD and expert group, 2011.

\subsubsection{Predictability of Work}

\section{Denmark}

To what extent do you get the information, you need to do your job well? NAK2005-136; 11 and NAK2010-25; 7

[manager] is good at planning the work? NAK2005-137; 3

\section{Finland}

No data

\section{Norway}

"Does your employer give you plenty of notice of important decisions, changes and future plans?"

\section{Sweden}

No data 
Predictability of Work

\begin{tabular}{|c|c|c|c|c|c|}
\hline & DK & FI & NO & SE & Total \\
\hline Overall grade & & & & & C \\
\hline 1. Relevance & $A$ & & A & & B \\
\hline 2. Accuracy & A & & A & & B \\
\hline 2. Cross-country comparable & & & & & B \\
\hline 3. Availability across countries & & & & & C \\
\hline 3. Availability over time & C & & B & & C \\
\hline Linkable & A & & C & & C \\
\hline Source and ownership & & & $\begin{array}{l}\text { Norwegian level of } \\
\text { living condition } \\
\text { survey - working } \\
\text { environment, SSB }\end{array}$ & & \\
\hline Accessible data? & Yes & & Yes & & \\
\hline
\end{tabular}

Source: DAMVAD and expert group, 2011.

\subsubsection{Motivation}

\section{Sweden}

How much of the time do you feel satisfied with your job? ECQ (is this right?)

\begin{tabular}{|c|c|c|c|c|c|}
\hline & DK & FI & NO & SE & Total \\
\hline Overall grade & & & & & c \\
\hline 1. Relevance & & & & A & C \\
\hline 2. Accuracy & & & & A & C \\
\hline 2. Cross-country comparable & & & & & c \\
\hline 3. Availability across countries & & & & & C \\
\hline 3. Availability over time & & & & B & C \\
\hline Linkable & & & & Yes & \\
\hline \multirow[t]{6}{*}{ Source and ownership } & & & & WES: The Swedish & \\
\hline & & & & Work Environment & \\
\hline & & & & Survey. SCB and & \\
\hline & & & & Swedish Work & \\
\hline & & & & Environment & \\
\hline & & & & Authority & \\
\hline Accessible data? & & & & Yes & \\
\hline
\end{tabular}

Source: DAMVAD and expert group, 2011. 


\subsubsection{Work-Reward Balance}

\section{Denmark}

No direct measures

\section{Finland}

WHS: QJ21B

\section{Norway}

"To what extent do you agree or disagree with the following statement? My salary is appropriate to my efforts and performance at work"

"To what extent do you agree or disagree with the following statement? In relation to my efforts and performance, I get the respect and recognition that I deserve at work."

\section{Sweden}

Can you receive support and encouragement from your superiors when your work becomes troublesome? WES

How do you experience your work? Extremely meaningless work WES

Can you receive support and encouragement from your fellow workers when your work becomes troublesome? WES

Do other persons express appreciation for your work (e.g. fellow workers, patients, customers, clients, passengers, students)? WES

How do you experience your work? Very unhappy with my working hours WES

Overall I feel good ECQ

I think my workload is reasonable, i.e. not excessive ECQ

My situation at work gives me the possibility to have balance between work and spare time ECQ

Expectations placed on me are compatible with my competence ECQ

On the whole I am happy with my salary discussion ECQ 


\begin{tabular}{|c|c|c|c|c|c|}
\hline & DK & FI & No & SE & Total \\
\hline Overall grade & & & & & B \\
\hline 1. Relevance & & B & A & $A$ & B \\
\hline 2. Accuracy & & A & A & $A$ & $A$ \\
\hline 2. Cross-country comparable & & & & & B \\
\hline 3. Availability across countries & & & & & B \\
\hline \multirow[t]{2}{*}{ 3. Availability over time } & & B & B & B: WES & B \\
\hline & & & & A: ECQ & \\
\hline \multirow[t]{2}{*}{ Linkable } & & C & C & WES: A & C \\
\hline & & & & ECQ: C & \\
\hline \multirow[t]{2}{*}{ Source and ownership } & & & Norwegian level of living condition & WES & \\
\hline & & & survey - working environment, SSB & ECQ & \\
\hline Accessible data? & & & Yes & Yes & \\
\hline
\end{tabular}

Source: DAMVAD and expert group, 2011.

\subsection{Indicators Regarding Well-Being}

\section{Norway}

General comment

There is little or no available data regarding well-being at company level. That implies that all questions reported under this section are based on survey data. The data can, however, be aggregated for occupational groups, industries or sectors.

\subsubsection{Yearly Amount Of Work Related Diagnoses}

- How many work related diagnoses per year in the company?

\section{Denmark}

Description: Often, it is not possible to decide, whether diagnoses are workrelated or not. The subject is not covered by VOV. NAK has questions broadly aimed at diagnosed illnesses.

Have you ever been told by a medical doctor that you suffered from one of the following conditions (15 response categories in NAK2005 and 9 response categories in NAK2010). NAK2005-58 og NAK2010-48

\section{Finland}

EODS

$\mathrm{SF}$ 


\section{Norway}

Description: Source 1

A national registry based on medical doctors reporting to The Labour Inspectorate, age, sex, diagnosis and occupation is available in the registry, industrial branch not available, and company not available

Description: Source 2

EUROSTAT survey on accident and disesases (as a part if the labour force survey )- Statistics Norway, last undertaken in 2007, questions about occupational diseases:Q7 (Apart from the accident you have told me about), within the last 12 months have you suffered from any illness, disability or other physical or mental problem?

- Q7a Are any of these an illness that you consider caused or been made worse by your job or by work you have done in the past?

- Q8 How many illnesses have you had (in the last 12 months) that have been caused or made worse by your work?

- Q9 In the following questions (Q10-Q13) please consider the most serious one the illnesses you suffered during the last 12 months and which were caused of made worse by your work.

\section{Sweden}

OAC Diagnoses of work related diseases

\begin{tabular}{|c|c|c|c|c|c|}
\hline & DK & FI & NO & SE & Total \\
\hline Overall grade & & & & & B \\
\hline \multirow[t]{2}{*}{ 1. Relevance } & A & B & 1: C (5 pct. reporting) & A & B \\
\hline & & & 2: A & & \\
\hline \multirow[t]{2}{*}{ 2. Accuracy } & A & A & 1: A & A & A \\
\hline & & & $2: A$ & & \\
\hline 2. Cross-country comparable & & & & & B \\
\hline $\begin{array}{l}\text { 3. Availability across coun- } \\
\text { tries }\end{array}$ & & & & & A \\
\hline \multirow[t]{2}{*}{ 3. Availability over time } & C & A & 1: A & A & B \\
\hline & & & 2: C & & \\
\hline \multirow[t]{2}{*}{ Linking possibility } & A & C & 1: C & A & C \\
\hline & & & 2: C & & \\
\hline \multirow[t]{5}{*}{ Source and ownership } & NAK, NFA & EODS & 1: Labour Inspectorate & OAC & \\
\hline & & SF & 2: The Labour force & & \\
\hline & & & survey 2007 ad hoc & & \\
\hline & & & module, Statistics & & \\
\hline & & & Norway, EUROSTAT & & \\
\hline \multirow[t]{2}{*}{ Accessible data? } & & & 1: Yes & & \\
\hline & & & 2: Yes & & \\
\hline
\end{tabular}

Source: DAMVAD and expert group, 2011. 


\subsubsection{Yearly Amount of Reporting Sick or III}

- How many workers report sick or ill for how many days per year

\section{Denmark}

Description: Not covered by VOV.

How many days did you report sick last year? NAK2005-146 og NAK2010-33

\section{Finland}

WCB

LFS

\section{Norway}

The Norwegian Labour and Welfare Administration: Registry data on sick leave, the sick leave percentage (lost days of possible working days yearly). Data available at present are aggregated by sex, age, 47 occupational groups, industrial branch and region.

\section{Sweden}

OAC Number of reported cases

OAC Number of reported work accidents which has caused sick-leave ( $>14$ days or $<15$ days)

OAC Number of reported work ilnesses which has caused sick-leave ( $>14$ days or $<15$ days)

LISA total amount of sick-leave for males and females and different ages

\begin{tabular}{|c|c|c|c|c|c|}
\hline & DK & FI & NO & SE & Total \\
\hline Overall grade & & & & & A \\
\hline 1. Relevance & A & B & A & A & B \\
\hline 2. Accuracy & A & A & A & A & A \\
\hline $\begin{array}{l}\text { 2. Cross-country compara- } \\
\text { ble }\end{array}$ & & & & & A \\
\hline $\begin{array}{l}\text { 3. Availability across } \\
\text { countries }\end{array}$ & & & & & A \\
\hline 3. Availability over time & C & A & A & A & B \\
\hline Linking possibility & A & C & (?) & A & B \\
\hline Source and ownership & NAK, NFA & $\begin{array}{l}\text { WCB } \\
\text { LFS }\end{array}$ & $\begin{array}{l}\text { The Norwegian Labour } \\
\text { and Welfare Admin- } \\
\text { istration }\end{array}$ & $\begin{array}{l}\text { OAC } \\
\text { LISA }\end{array}$ & \\
\hline Accessible data? & & & Yes & & \\
\hline
\end{tabular}

Source: DAMVAD and expert group, 2011. 


\subsubsection{Short Term Sickness}

OAC Number of reported work accidents which has caused sick-leave ( $>$ 14 days or $<15$ days)

OAC Number of reported work ilnesses which has caused sick-leave ( $>14$ days or $<15$ days)

Short term sickness

\begin{tabular}{|c|c|c|c|c|c|}
\hline & DK & $\mathbf{F I}$ & NO & SE & Total \\
\hline Overall grade & & & & & C \\
\hline 1. Relevance & & & & $A$ & C \\
\hline 2. Accuracy & & & & A & C \\
\hline 2. Cross-country comparable & & & & & C \\
\hline 3. Availability across countries & & & & & C \\
\hline 3. Availability over time & & & & A & c \\
\hline Linking possibility & & & & A & C \\
\hline Source and ownership & & & & OAC & \\
\hline Accessible data? & & & & & \\
\hline
\end{tabular}

Source: DAMVAD and expert group, 2011.

\subsubsection{Long Term Sickness}

- What is the number of employees away because of long term illnesses?

- How long are average periods of sicknesses

\section{Denmark}

Description: Information obtainable from the Danish DREAM-data, a longitudinal data set containing information about all and every instance of pay-out from public benefit schemes. On a weekly basis.

\section{Finland}

SSI

\section{Norway}

The Norwegian Labour and Welfare Administration: Registry data sick leave $16 \mathrm{~d}+$, number of sick-leave cases (not number of workers), occupation, industrial branch, region, age, groups, sex, selected diagnosis.

\section{Sweden}

OAC Number of reported work accidents which has caused sick-leave (> 14 days or $<15$ days)

OAC Number of reported work ilnesses which has caused sick-leave ( $>14$ days or $<15$ days)

LISA sick-leave $>60$ days 


\begin{tabular}{|c|c|c|c|c|c|}
\hline & DK & FI & NO & SE & Total \\
\hline Overall grade & & & & & B \\
\hline 1. Relevance & A & A & A & A & A \\
\hline 2. Accuracy & A & A & A & $A$ & A \\
\hline $\begin{array}{l}\text { 2. Cross-country compa- } \\
\text { rable }\end{array}$ & & & & & A \\
\hline $\begin{array}{l}\text { 3. Availability across } \\
\text { countries }\end{array}$ & & & & & A \\
\hline 3. Availability over time & C & A & $\mathrm{B} / \mathrm{C}$ & $A$ & B \\
\hline Linking possibility & A & C & (?) & A & B \\
\hline Source and ownership & DREAM, AMS & SSI & $\begin{array}{l}\text { The Norwegian Labour } \\
\text { and Welfare Administra- } \\
\text { tion: }\end{array}$ & $\begin{array}{l}\text { OAC } \\
\text { LISA }\end{array}$ & \\
\hline Accessible data? & & & Yes & & \\
\hline
\end{tabular}

Source: DAMVAD and expert group, 2011.

\subsubsection{Mortality Rates}

- What is the mortality rate among workers in a company

\section{Denmark}

Description: Information about mortality is obtainable from the "Cause of Death Register".

\section{Finland}

SF

\section{Norway}

No data

\section{Sweden}

No data

\begin{tabular}{|c|c|c|c|c|c|}
\hline & DK & $\mathbf{F I}$ & NO & SE & Total \\
\hline Overall grade & & & & & C \\
\hline 1. Relevance & $A$ & $A$ & & - & B \\
\hline 2. Accuracy & A & $A$ & & - & B \\
\hline 2. Cross-country comparable & & & & & A \\
\hline 3. Availability across countries & & & & & C \\
\hline 3. Availability over time & A & A & & - & B \\
\hline Linking possibility & A & C & & - & c \\
\hline Source and ownership & Dødsårsags-registret (?) & $\mathrm{SF}$ & & - & \\
\hline Accessible data? & & & - & - & \\
\hline
\end{tabular}

Source: DAMVAD and expert group, 2011. 


\subsubsection{Average Retirement Age}

- The average age of retirement

\section{Denmark}

Description: Information about retirement age obtainable from the Danish DREAM-data, a longitudinal data set containing information about all and every instance of pay-out from public benefit schemes. On a weekly basis.

\section{Finland}

SF

\section{Norway}

No data

\section{Sweden}

No data

\begin{tabular}{|c|c|c|c|c|c|}
\hline & DK & FI & NO & SE & Total \\
\hline Overall grade & & & & & C \\
\hline 1. Relevance & A & A & - & - & B \\
\hline 2. Accuracy & A & $A$ & - & - & B \\
\hline 2. Cross-country comparable & & & & & B \\
\hline 3. Availability across countries & & & & & C \\
\hline 3. Availability over time & A & A & - & - & A \\
\hline Linking possibility & A & $C$ & - & - & c \\
\hline Source and ownership & DREAM, AMS & SF & - & - & \\
\hline Accessible data? & & & - & - & \\
\hline
\end{tabular}

Source: DAMVAD and expert group, 2011.

\subsubsection{Number of Recipients of Benefits for Those Unfit to Work}

\section{Denmark}

Description: Information obtainable from the Danish DREAM-data, a longitudinal data set containing information about all and every instance of pay-out from public benefit schemes. On a weekly basis.

\section{Finland}

SSI

\section{Norway}

The Norwegian Labour and Welfare Administration: Registry data number of workers with maximum sick leave benefits (12 months) and number of recipients of benefits for those unfit to work. Data on maxi- 
mum sick leave benefits available at present are aggregated by sex, age, 47 occupational groups, industrial branch, and region. For a number of recipients of benefits for those unfit to work occupational group is not available.

\section{Sweden}

No data

Benefits for Those Unfit to Work

\begin{tabular}{|c|c|c|c|c|c|}
\hline & DK & FI & NO & SE & Total \\
\hline Overall grade & & & & & C \\
\hline 1. Relevance & A & A & A & - & A \\
\hline 2. Accuracy & A & A & A & - & A \\
\hline \multicolumn{6}{|l|}{ 2. Cross-country comparable } \\
\hline 3. Availability across countries & & & & & B \\
\hline 3. Availability over time & A & A & A & - & A \\
\hline Linking possibility & A & C & C & - & C \\
\hline Source and ownership & $\begin{array}{l}\text { DREAM, } \\
\text { AMS }\end{array}$ & SSI & $\begin{array}{l}\text { The Norwegian Labour and } \\
\text { Welfare Administration }\end{array}$ & - & \\
\hline Accessible data? & & & Yes & - & \\
\hline
\end{tabular}

Source: DAMVAD and expert group, 2011.

\subsubsection{Work Related Injuries}

\section{Denmark}

Description: Not covered in VOV.

NAK2005-116: How many work related accidents have you experienced within the last 12 months, which led to absence from work for longer than the day of the accident?

NAK2010-11: Have you, within the last 12 months, experienced a work-related accident, which led to your absence from work for longer than the day of the accident?

NAK2005-117: How many days were you absent as a consequence of the accident, except for the day of the accident?

NAK-2005-118: What happened? (9 response categories)

NAK2005-119 og NAK2010-11b: Were you given hospital treatment after the accident?

NAK2005-120: Did the accident occur during your usual work?

NAK2005-121: What is the risk that you, within the next 12 months, will be hurt at work in a way causing you to stay home for at least one day? 


\section{Finland}

$\mathrm{SF}$

TVL

\section{Norway}

The best available source is EUROSTAT survey on accident and disesases (as a part of the labour force survey )- Statistics Norway, last undertaken in 2007, questions about occupational diseases: [?]

\section{Sweden}

OAC Number of reported cases split up on different categories (causes) as well as occupations

\begin{tabular}{|c|c|c|c|c|c|}
\hline & DK & $\mathbf{F I}$ & NO & SE & Total \\
\hline Overall grade & & & & & C \\
\hline 1. Relevance & A & A & A & - & A \\
\hline 2. Accuracy & A & A & A & - & $A$ \\
\hline 2. Cross-country comparable & & & & & B \\
\hline 3. Availability across countries & & & & & B \\
\hline 3. Availability over time & C & A & C & - & C \\
\hline Linking possibility & A & C & - & - & C \\
\hline Source and ownership & NAK, NFA & $\begin{array}{l}\text { SF } \\
\text { TVL }\end{array}$ & $\begin{array}{l}\text { The Labour force } \\
\text { survey } 2007 \text { ad } \\
\text { hoc module, } \\
\text { Statistics Norway, } \\
\text { EUROSTAT }\end{array}$ & - & \\
\hline Accessible data? & & & Yes & - & \\
\hline
\end{tabular}

Source: DAMVAD and expert group, 2011.

\subsubsection{Self-Reported Work-Related Health Problems}

\section{Denmark}

Description: Most people are incapable of judging themselves, whether their health problems are work-related or not. In NAK, therefore, we ask in general to the occurrence of a range of health problems, which are then related statistically to the reporting of different work environment problems.

Self-reported health in general: NAK-2005-18 og NAK2010-52

Unspecified "subjective health complaints" NAK-2005-57;1-26 and Nak2010-53; 1-19

Physical pain and conditions: NAK2005-42-43-44-45-46-47-48-4950-51 and NAK2010-40-41-42-43-44-45-46-47 
Psychological well-being, stress, and depression NAK2005-19 and 23 and NAK2010-49-50-51

\section{Finland}

EWCS: Q69A-N

\section{Norway}

The living condition survey (population sample) has several questions regarding self-reported work-related health problems. The data can be aggregated for occupational groups, industries or sectors. A list:

- Have you, over the past month, been Severly afflicted from,Somewhat afflicted from, A little afflicted from or not afflicted at all from. If the subject is afflicted they are asked is this wholly or partly due to your current job ...

- pain in the small or lower part of the back?

- pains in your neck and/or shoulders?

- pains in your elbows, lower arms or hands?

- pains in your hips, legs, knees or feet?

- headaches or migraines? eczema, itchy skin or rash?

- eye irritations such as itchy, tender, red or runny eyes?

- hearing problems, which have made it difficult for you to follow conversations when several people are talking, or have you experienced tinnitus?

- nervousness, anxiety or restlessness?

- dejection or depression?

- sleep disruptions, such as problems falling asleep, waking up too early or getting too little sleep?

- stomach pain and/or diarrhoea?respiratory problems, such as coughing, mucus, shortness of breath or wheezing?

Heart problems:

- Do you get chest pains or discomfort when walking up hills, climbing steps or walking fast on the flat?

- If you do experience pain when walking, do you normally stop, slow down or continue at the same speed?

- If you stop or slow down, does the pain go away in less than 10 minutes or more than 10 minutes?

- Are you just as likely to experience that kind of pain when resting?

Within the file the exposure and outcome data are linked (cross-sectional data), we also have panel data where the same person is followed over time (three years intervals). Not possible to link to companies. 


\section{Sweden}

WES How often during the past 12 months have you attended work although you, considering your state of health, should have reported sick?

WES After work, do you experience pain in any of the following places...

...upper parts of your back or neck?

...lower parts of your back?

...shoulders or arms?

...wrists or hands?

...hips, legs, knees, or feet?

WES Does it happen that you are physically exhausted when you get home from work?

WES Does it happen that you cannot dismiss your job from your thoughts when you are off work?

WES Have you during the last three months...

...had heartburn, acid burping, burn in the pit of your stomach, or upset stomach?

...been tired and listless?

...had headaches?

...had itching or other irritation in your eyes?

...had a hard time sleeping because thoughts about your work keep you awake?

WES Does it happen that you feel ill at ease going to your job?

WES Does it happen that you feel uneasy and despondent as a result of difficulties you are facing at work?

WES Does it happen that after the end of your work day you feel that your work contributions have been insufficient?

WES Does it happen that you after work are too tired or don't have enough time for your family, friends or leisure activities?

ECQ: Overall I feel good

RESEARCH Subjective appreciation of stress correlates with productivity (found in many studies e.g., Aldana, 2001) 


\begin{tabular}{|c|c|c|c|c|c|}
\hline & DK & FI & NO & SE & Total \\
\hline Overall grade & & & & & C \\
\hline 1. Relevance & A & B & A & A & $A$ \\
\hline 2. Accuracy & A & A & A & B & $A$ \\
\hline 2. Cross-country comparable & & & & & $A$ \\
\hline 3. Availability across countries & & & & & $A$ \\
\hline 3. Availability over time & C & C & B & B & $\mathrm{C}$ \\
\hline \multirow[t]{2}{*}{ Linking possibility } & A & C & C & A & C \\
\hline & & & & ECQ: C & \\
\hline \multirow[t]{2}{*}{ Source and ownership } & NAK & EWCS & Norwegian living condition & WES & \\
\hline & & & survey, Statistics Norway & ECQ & \\
\hline Accessible data? & & & Yes & & \\
\hline
\end{tabular}

Source: DAMVAD and expert group, 2011.

\subsubsection{Number of Work Related Deaths}

- The number of deaths related to work

\section{Denmark}

Description: No reliable information.

\section{Finland}

SF

TVL

\section{Norway}

Data from the various Governmental Inspectorates, and based on this provided yearly national data, we do not have access to demographic variables, occupation, industrial branch etc.

\section{Sweden}

Not reported 


\begin{tabular}{|c|c|c|c|c|c|}
\hline & DK & FI & NO & SE & Total \\
\hline Overall grade & & & & & C \\
\hline 1. Relevance & - & A & B & A & B \\
\hline 2. Accuracy & - & A & - & A & B \\
\hline 2. Cross-country comparable & & & & & C \\
\hline 3. Availability across countries & & & & & B \\
\hline 3. Availability over time & - & A & - & A & A \\
\hline Linking possibility & - & C & - & A & C \\
\hline Source and ownership & - & $\begin{array}{l}\text { SF } \\
\text { TVL }\end{array}$ & $\begin{array}{l}\text { Faktabok 2011, } \\
\text { NOA, STAMI } \\
\text { (available 2011) }\end{array}$ & Med & \\
\hline Accessible data? & & & Yes & & \\
\hline
\end{tabular}

Source: DAMVAD and expert group, 2011.

\subsubsection{Stress}

- Number of employees with stress

\section{Denmark}

Description: Not covered in VOV.

It is difficult to ask directly to stress in a questionnaire, as the subject is very vaguely defined and has many meanings. Instead, we prefer asking, in the NAK-survey, about symptoms, which can be stress related, as for instance low quality of sleep, low vitality, etc.

Psychological well-being, stress, and depression NAK2005-19 and 23 and NAK2010-49-50-51

\section{Finland}

WHS: QJ1

EWCS: Q51N

\section{Norway}

Questions in the living condition survey (population sample) which indirectly can be used as surrogate for work related stress. Same dataset as for work related health problems:

- Have you, over the past month, been Severly afflicted from, Somewhat afflicted from, A little afflicted from or not afflicted at all from. If the subject is afflicted they are asked is this wholly or partly due to your current job ...

- nervousness, anxiety or restlessness?

- dejection or depression? 
- sleep disruptions, such as problems falling asleep, waking up too early or getting too little sleep?

- stomach pain and/or diarrhoea? respiratory problems, such as coughing, mucus, shortness of breath or wheezing?

Heart problems:

- Do you get chest pains or discomfort when walking up hills, climbing steps or walking fast on the flat?

- If you do experience pain when walking, do you normally stop, slow down or continue at the same speed?

- If you stop or slow down, does the pain go away in less than 10 minutes or more than 10 minutes?

Are you just as likely to experience that kind of pain when resting?

\section{Sweden}

\begin{tabular}{|c|c|c|c|c|c|}
\hline & DK & FI & NO & SE & Total \\
\hline Overall grade & & & & & c \\
\hline 1. Relevance & B & B & B & $A$ & B \\
\hline 2. Accuracy & B & A & A & A & A \\
\hline 2. Cross-country comparable & & & & & B \\
\hline 3. Availability across countries & & & & & A \\
\hline 3. Availability over time & C & $\begin{array}{l}\text { WHS: B } \\
\text { EWCS: C }\end{array}$ & B & A & C \\
\hline Linking possibility & A & C & C & A & C \\
\hline Source and ownership & NAK, NFA & $\begin{array}{l}\text { WHS } \\
\text { EWCS }\end{array}$ & $\begin{array}{l}\text { Norwegian living } \\
\text { condition survey, } \\
\text { Statistics Norway }\end{array}$ & MED & \\
\hline Accessible data? & & & Yes & & \\
\hline
\end{tabular}

Source: DAMVAD and expert group, 2011.

\subsubsection{Depression}

- Number of employees with a depression

\section{Denmark}

Description: Not covered by VOV.

NAK2005-19; 1-12. This tool for investigating on mental health (depression) was in NAK2010-50; 1-12 replaced by a stronger tool, which is a significant part of the recognised Major Depression Inventory (MDI) 


\section{Finland}

WHS: QT5A-B

ECWS: Q69K

\section{Norway}

- Have you, over the past month, been Severly afflicted from, Somewhat afflicted from, A little afflicted from or not afflicted at all from. If the subject is afflicted they are asked is this wholly or partly due to your current job been in a state of low mood or depressed?

\section{Sweden}

No description

\begin{tabular}{|c|c|c|c|c|c|}
\hline & DK & FI & NO & SE & Total \\
\hline Overall grade & & & & & C \\
\hline 1. Relevance & A & B & A & A & A \\
\hline 2. Accuracy & A & A & A & A & A \\
\hline 2. Cross-country comparable & & & & & C \\
\hline 3. Availability across countries & & & & & A \\
\hline 3. Availability over time & C & $\begin{array}{l}\text { WHS: B } \\
\text { ECWS: C }\end{array}$ & B & A & C \\
\hline Linking possibility & A & C & A & C & C \\
\hline Source and ownership & $\begin{array}{l}\text { NAK, } \\
\text { NFA }\end{array}$ & $\begin{array}{l}\text { WHS } \\
\text { ECWS }\end{array}$ & $\begin{array}{l}\text { Norwegian living } \\
\text { condition survey, } \\
\text { Statistics Norway }\end{array}$ & MED & \\
\hline Accessible data? & & & Yes & & \\
\hline
\end{tabular}

Source: DAMVAD and expert group, 2011. 